\title{
A때
}

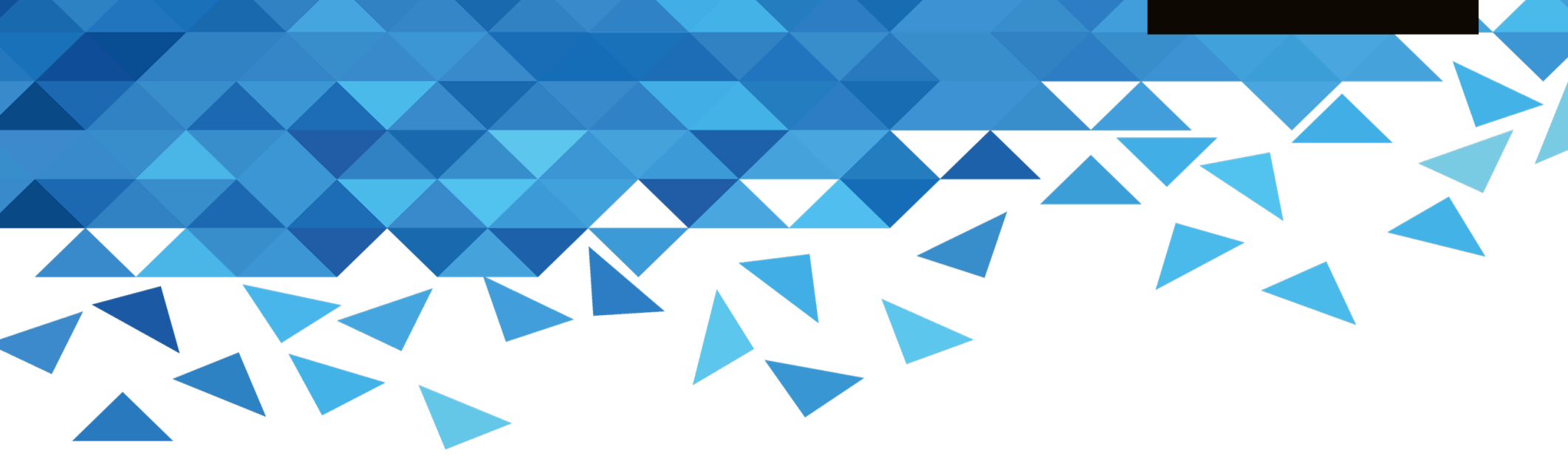

Economics Working Paper Series

Faculty of Business, Economics and Law, AUT

\section{The Effect of Interest Rate Caps on Bankruptcy: Synthetic Control Evidence from Recent Payday Lending Bans}

Kabir Dasgupta Brenden J. Mason

$2019 / 04$ 


\title{
The Effect of Interest Rate Caps on Bankruptcy: Synthetic Control Evidence from Recent Payday Lending Bans
}

\author{
Kabir Dasgupta* and Brenden J. Mason ${ }^{\dagger}$
}

\begin{abstract}
Citing consumer protection concerns, New Hampshire-along with three other states-recently banned payday lending by implementing an APR cap on small loans. New Hampshire presents a compelling quasi-experiment: its neighbors already had a payday loan ban in place. Hence, New Hampshire consumers were completely shut out of the storefront payday loan market. We perform a synthetic control analysis for all four of the recently-banning states. Our results show that, on the aggregate, bankruptcies are largely unaffected by the bans. Our New Hampshire results are characterized by an initial rise in bankruptcies after the ban, followed by a fall. This is consistent with the notion that payday bans hurt credit-constrained consumers in the short-run, but could help them in the long-run. We also analyze survey data of payday borrowers and find that while bankruptcies are unaffected, consumers substitute toward paying their credit card bills late and using pawnshops.
\end{abstract}

JEL Classification: G23, G28, D12; C13

Keywords: Interest rate cap; Payday lending; Credit rationing; Bankruptcy; Informal bankruptcy; Synthetic control; ArCo

${ }^{*}$ Research Fellow, New Zealand Work Research Institute, Auckland University of Technology, Auckland, New Zealand

${ }^{\dagger}$ Assistant Professor of Economics, North Central College, Naperville, IL, United States

${ }^{\ddagger}$ Correspondence: New Zealand Work Research Institute, Auckland University of Technology, Private Bag 92006, Auckland 1142, New Zealand. E-mail address: kabir.dasgupta@aut.ac.nz 


\section{Section 1: Introduction}

Payday loans are unsecured short-term high-interest loans, with a maturity of about two weeks and a typical annualized percentage rate (APR) of 390\%, possibly more if the loan is rolled over (Edmiston (2011)). To apply for a loan, a borrower must show a valid ID, a bank statement, and proof of stable income, e.g., several successive paystubs of some kind. The potential borrower writes a check for the full amount (principal plus interest and fees), post-dated for the maturity date of the loan. The lender cashes the check on the loan due date, unless the borrower rolls over the loan for an additional fee, which happens approximately $80 \%$ of the time (CFPB (2014)).

As of 2016, approximately twelve million Americans use payday loans annually, amounting to a total of nine billion dollars in fees alone (Pew (2012)). Since the mid-90s, payday lenders have been growing in number (Stegman (2007)), and now total more locations than Starbucks and McDonalds combined (Skiba and Tobacman (2011)). Citing consumer protection concerns, legislatures around the country have responded. At the federal level, the Dodd-Frank Act created the Consumer Financial Protection Bureau, a bureau that polices the industry. Moreover, in 2006, the federal government enacted the Military Lending Act, which capped unsecured loans to military members at $36 \%$ APR, effectively banning payday lending for military personnel. At the state level, states have enacted various restrictions on payday lending, from limiting the number of rollovers (Washington), to capping the APR at 36\% (e.g. New Hampshire, Montana, and South Dakota). ${ }^{1}$

Such payday lending restrictions have some justification. For instance, there is evidence that access to payday loans leads consumers to do the following: delay health care, increase their reliance on food assistance programs, lower job performance, file for bankruptcy, consume more alcohol, commit more crime, and even contemplate suicide. ${ }^{2}$ There is also evidence that payday lenders engage in shady marketing tactics (Stegman (2007)) and target regions with a high prevalence of demographic minorities such as African-American neighborhoods (Barth, Hilliard, Jahera, and Sun (2016)).

\footnotetext{
${ }^{1}$ See the Appendix Table A.1 for a history of payday lending legislation in each state and the District of Columbia.

${ }^{2}$ For general economic hardship and delayed healthcare see Melzer (2011), but cf. Dobridge (2018). For an increase of use of food assistance see Melzer (2013). For lower job performance see Carrell and Zinman (2014), but cf. Carter and Skimmyhorn (2017) and Karlan and Zinman (2010). For bankruptcy, see Hynes (2012), Skiba and Tobacman (2011), and Morgan, Strain, and Seblani (2012). For alcohol expenditures, see Zaki (2016) and Cuffe and Gibbs (2017). For crime see Xu (2016), but cf. Morse (2011). For suicide risk see Lee (2017).
} 
Despite the justification for payday restrictions, there may be some unintended consequences. Recent evidence has shown that payday loan restrictions have pushed consumers into less desirable forms of finance, including bank overdraft fees, bill delinquency, and pawnshop loans. ${ }^{3}$ Interestingly, Morgan et al. (2012) find that although bankruptcies decrease after a payday lending ban, complaints against debt collectors increase substantially. The authors hypothesize that payday loans were helping stave off informal bankruptcy that is, become delinquent on their debts (see Morgan et al. (2012)). States that remove payday lending as a financing option inadvertently push consumers to become delinquent and deal with the hassle of debt collectors.

In this paper, we test whether recent state-level payday restrictions affect bankruptcy, either informal bankruptcy through loan delinquencies, or formally through Chapter 13 and Chapter 7 filings. Between 2009 and 2011 four states-Arkansas, Arizona, Montana, and New Hampshireinstituted interest rate caps, e.g., loans cannot exceed 36\% APR. For each of these states, we perform a synthetic control analysis, and for the state of New Hampshire, we perform a very recent extension of the synthetic control method known as articficial counterfactual (ArCo). We first consider the question of whether the interest rate cap had its intended effect of reducing payday loan usage. Then, we compare the number of delinquencies and bankruptcy filings before and after each state's respective ban relative to its synthetic control unit. We then analyze alternatives to payday lending, i.e., did consumers substitute to an alternative source of shortterm credit as a result of the interest rate cap?

Our findings show that the interest rate caps were indeed effective at eliminating the payday lending industry. Survey evidence from two sources (FDIC and FINRA) shows that consumers reduced their payday loan usage. Furthermore, the number of payday lending establishments (NAICS code 522390) plummets relative to its synthetic control unit after the passage of the interest rate cap. Our synthetic control evidence and our survey evidence from FINRA show that bankruptcies and delinquencies, on the other hand, are generally unchanged as a result of the interest rate cap

\footnotetext{
${ }^{3}$ Edmiston (2011) shows that the typical bank overdraft fees (and credit card overcharges) are often higher than a payday loan. He also argues that payday loans are more convenient than alternative high-interest loans. For evidence that payday lending restrictions lead to more involuntary bank closures-which are almost always the result of delinquent overdrafts-see Gathergood, Guttman-Kenney, and Hunt (2019) and Bhutta, Goldin, and Homonoff (2016), but cf. D. Campbell, Martinez-Jerez, and Tufano (2012). For overdraft fees, see Stegman (2007), Melzer and Morgan (2015), Morgan et al. (2012), and Zinman (2010). For bill delinquency, see Desai and Elliehausen (2017). For pawnshop loans, see Bhutta et al. (2016) and Ramirez (2017). For the effect of payday lending restrictions on credit scores generally, see Edmiston (2011), Bhutta (2014), and Bhutta, Skiba, and Tobacman (2015).
} 
To be sure, the story is a bit more nuanced. In New Hampshire - a state that presents the strongest case of a state-level quasi-experiment since its neighbors have always banned payday lending - we find a suggestive pattern: bankruptcies initially increase after the ban, which suggests that payday loans were keeping at least some consumers afloat. ${ }^{4}$ However, after some time, the bankruptcy rate falls (relative to synthetic New Hampshire), which implies that in the longrun the ban may have its intended effect of getting people to be more financially healthy. One mechanism could be better budgeting. Pew (2012) conducted in-depth focus groups of payday borrowers. In response to the question 'what would you do if there were no payday lenders', many people noted that they would manage their finances better, including making a budget. If creating a budget (and learning to stick to it) takes time, then it's possible that the payday lending ban acts as a type of commitment mechanism for consumers, "forcing" their hand in creating and sticking to a budget.

If the interest rate caps are an effective ban on payday loans, where did all of the former payday loan borrowers go for short-term financing? We consider a half-dozen high-interest alternatives, including credit card over-limit fees, credit card cash advances, credit card late fees, overdraft fees, pawnshop usage, and petty crime. The only statistically-meaningful change in these alternative channels comes from credit card late fees and pawnshop usage, both of which increase as a result of the ban. A revealed preference argument would suggest that these consumers are likely worse off-at least in the short-run - as a result of the interest rate cap.

As a whole, our results complement two of the most recent studies that we believe have the highest degree of internal validity: Bhutta et al. (2015) and Gathergood et al. (2019). Bhutta et al. (2015) identify the causal effect of payday loan access on credit scores by analyzing a unique data set on payday loan approvals. They compare the financial outcomes of those who were 'barely approved' for a loan to those who were 'barely denied' in a fuzzy regression discontinuity

\footnotetext{
${ }^{4}$ Strictly speaking, we classify Maine as only partially restrictive with respect to its payday lending legislation. Maine has an interest rate cap, but allows exceptions. See the Appendix Table A.1 for details. We also verified the illegality of payday lending in Maine, e.g., online lenders attempting to circumvent the law, by examining the qualitative payday lending complaints made to the CFPB. See https://www.consumerfinance.gov/dataresearch/research-reports/?topics=payday-loans and complaints \#1408305, \#1346867; and \#1354340 as examples demonstrating the nationwide market leaders in payday loans, Advance America, does not operate any stores in Maine. See https://www.sec.gov/Archives/edgar/data/1299704/000104746912002758/a2208026z10-k.htm. Quebec has a longstanding 35\% APR interest rate cap on small loans. See Buckland, Robinson, and Visano (2018) for details on payday lending in Quebec, and Canada more generally. Of course, its possible that consumers turn to online payday loans. While this possibility is inevitable, Pew (2012) show that consumers are hesitant to take out payday loans online. Borrowers are not comfortable giving out their financial information online due to concerns about identity theft. In our results section, we show that payday loan usage of any kind decreased after states passed their respective interest rate caps.
} 
framework; credit scores are unaffected. Gathergood et al. (2019) also employ a fuzzy regression discontinuity design, but use data from nearly every payday loan application in the UK over a two-year period. These authors find an increase in financial distress, e.g., delinquencies, immediately after being denied a loan, but eventually the applicant becomes more financially healthy relative to the group that was approved.

The credibility of these studies comes from their impeccable degree of internal validity. However, this credibility inevitably comes at the cost of external validity: what about those borrowers who are "far away" from the respective thresholds? We believe that our study (in addition to studies like Bhutta (2014) and Bhutta et al. (2016)) fill this gap. Our results go in the 'opposite direction', as it were. With respect to New Hampshire specifically, we believe that our results have a high degree of external validity because we use aggregate state-level data on bankruptcies, bolstered by a nationally-representative survey of a population of payday borrowers. Therefore, our results, when coupled with the previous findings, paint a fuller picture of the costs and benefits of payday loan bans.

The paper proceeds as follows. The second section reviews the literature that most directly links payday lending to bankruptcies. The third section briefly describes the state-level regulatory framework in the United States. The fourth section describes the variables, data, and the empirical methodology. The fifth section describes the results. The sixth section concludes, frames the policy debate, and presents avenues of future research.

\section{Section 2: Previous Literature}

Given that credit and consumer protection are important topics, there is a lot of research on the effects of payday lending. In this section we limit the scope of our review to those studies that are most closely related to ours, that is, only those studies that examine the link between payday loan access and bankruptcy, both formal (Chapters 7 and 13) and informal (loan delinquencies).

Regarding formal bankruptcy, Lefgren and McIntyre (2009) analyze why bankruptcies filings differ across states since bankruptcy law is determined at the federal level. The authors find that demographic characteristics account for the bulk of the variation, leaving little to no explanatory room for strictness of payday legislation and usury laws. Stoianovici and Maloney (2010) exploit state variation in payday lending legislation between 1990 and 2006. They find no effect on bankruptcy rates, a result confirmed by Hynes (2012) for the period 1998-2009. Moreover, 
Table 1: Summary of Relevant Literature

\begin{tabular}{|c|c|c|c|}
\hline Author(s) & Year & $\begin{array}{l}\text { Measure of Payday } \\
\text { Loan Access }\end{array}$ & $\begin{array}{c}\text { Correlation of } \\
\text { Access and Bankruptcy }\end{array}$ \\
\hline \multicolumn{4}{|c|}{ Formal Bankruptcy: Chapter 7 or 13} \\
\hline Lefgren and McIntyre & 2009 & Legal restrictions & None \\
\hline Stoianovici and Maloney & 2010 & Number of stores & None \\
\hline Skiba and Tobacman & 2011 & Loan approval & Positive \\
\hline Hynes & 2012 & Legal restrictions & None \\
\hline Morgan, Strain, Seblani & 2012 & Legal restrictions & Positive \\
\hline Carter and Skimmyhorn & 2017 & Legal restrictions & None \\
\hline \multicolumn{4}{|c|}{ Informal Bankruptcy: Delinquencies and Defaults } \\
\hline Zinman & 2010 & Legal restrictions & Negative \\
\hline Morse & 2011 & Number of lenders & Negative \\
\hline Bhutta & 2014 & Legal restrictions & None \\
\hline Desai and Elliehausen & 2017 & Legal restrictions & None \\
\hline $\begin{array}{l}\text { Gathergood, Guttman-Kenney, } \\
\text { and Hunt }\end{array}$ & 2018 & Loan approval & Positive \\
\hline
\end{tabular}

Notes: Stoianovici and Maloney also examine legal restrictions and find no effect. Skiba and Tobacman (2011) is extended by Bhutta et al. (2015) by examining credit scores. Zinman (2010) finds evidence that banned payday borrowers pay their bills late, which, we argue, is correlated with bill delinquency. Desai and Elliehausen (2017) find that there may be some mixed evidence for the state of Georgia.

Stoianovici and Maloney perform Granger causality tests and find that the number of payday lending stores does not Granger cause bankruptcies.

The finding that payday lending restrictions do not affect bankruptcies is contrasted with the findings of Morgan et al. (2012). These authors exploit state-time variation in payday lending legislation and find that payday-banning states see a decrease in Chapter 13 bankruptcy rates relative to states that did not ban (note that by 'ban' we mean the imposition of an interest rate cap). Their findings suggest that the ban was helpful to consumers: bankruptcies were high; legislators passed the interest rate cap; bankruptcies fell. However, the authors caution against this knee-jerk interpretation of the results. They also find that overdraft fees and complaints against debt collectors also increase in the payday banning states. Therefore, the welfare effects of the payday ban are unclear.

Skiba and Tobacman (2011) echo Morgan et al., both in their findings and their interpretation. Skiba and Tobacman use a proprietary dataset from a payday lender in Texas and link the data to bankruptcy filings. These authors compare the bankruptcy outcomes of payday borrowers who were barely approved for a payday loan to those who were barely rejected for 
one. They find that being approved for a loan leads to a higher rate of bankruptcy filing. Bhutta et al. (2015) analyze the same dataset but link it to credit scores. These authors find that there is no material effect on credit scores.

Carter and Skimmyhorn (2017) find that bankruptcy rates (as well as delinquent payments) are unchanged for military members who are randomly assigned to 'payday banning' states relative to those who are assigned to 'payday permissive' states. Studying the military is particularly interesting because the Military Lending Act imposes an interest rate cap of $36 \%$ APR on all loans to members of the US military, regardless of state law. Regarding welfare effects, these authors suggest that the concerns about payday lending are "much ado about nothing."

Regarding informal bankruptcy, Zinman (2010) finds that Oregons 2007 interest rate cap led to consumers stating that they plan to pay their bills late relative to consumers in Washington, which is a permissive payday lending state. Morse (2011) finds that access to a payday lender mitigates home foreclosure rates among Californians who are hit by a natural disaster. Bhutta (2014) uses the methodology developed by Melzer (2011) to exploit the spatio-temporal variation in delinquencies (and credit scores) at the zip-code level. Bhutta (2014) finds that delinquencies (and credit scores) are unaffected by proximity to payday access. Specifically, he compares delinquencies in zip codes that are in a payday banning state to delinquencies of zip codes that are in the same state but geographically close to a payday permissive state. Desai and Elliehausen (2017) examine credit delinquencies in the counties of the banning states of Georgia, North Carolina, and Oregon before and after each states respective ban to neighboring counties that are located in states that did not ban. They generally find no effect, with Georgia's ban being an exception: revolving credit (e.g., credit cards) delinquencies increase, but installment credit (e.g., an auto loan) delinquencies decrease .

Gathergood et al. (2019) provide the most recent-and perhaps the most compelling-evidence on the effect of payday lending on delinquencies. These authors obtained payday loan data that includes virtually every payday loan approval in the entire United Kingdom for the years 2012 and 2013. The authors link this payday data to personal credit data. Exploiting the exogenous variation created by a threshold in payday loan approval, the authors find that delinquencies decline immediately after the loan is approved. However, in the longer-run, the situation is reversed: payday lending approval causes an increase in credit delinquencies. Table 1 summarizes our review of the most pertinent literature. 
Our paper adds to this literature in at least several ways. We provide an up-to-date, thorough classification of payday lending legislation by state, from which we perform a state-level difference-in-differences analysis. This is similar to several previous studies, but ours includes states that-to our knowledge-have yet to be studied, those being Arizona, Arkansas, New Hampshire, and Montana.

Furthermore, we believe that our paper can buttress the findings of Bhutta et al. (2015) and Gathergood et al. (2019) with respect to external validity. The Bhutta et al. (2015) data come from one payday lender, which leaves open the possibility that their results hold only for a particular population, e.g., maybe the payday lender has a brand that attracts applicants that differ systematically from the rest of the population of payday borrowers. While the Gathergood et al. (2019) data come from virtually all payday lenders, we don't know the effect of payday lending on those payday borrowers who are far away from the loan-approval threshold. In contrast to both of these studies, New Hampshire's effective payday ban applies to all payday lenders, regardless of their proximity to the loan-approval threshold. Of course, there is a "price" to pay for this increase in external validity, i.e., identifying the causal effect at the aggregate level is much more difficult. This is why we argue that our results complement these two existing studies.

At the same time, we believe that our paper is a strong counterpart to the zip/county/statelevel studies because we compare New Hampshire to synthetic New Hampshire, a state whose neighbors have stringent payday lending restrictions. In that regard, after the imposition of the interest rate cap, New Hampshirites have no feasible geographical alternative.

\section{Section 3: Regulatory Framework}

For our analysis, we rely on the synthetic control method pioneered by Abadie, Diamond, and Hainmueller (2010). Before to describing the empirical framework, we first discuss the basis on which we select the group of comparable states for the states that prohibited payday lending from 2009 onwards. Table 2 summarizes the underlying reasons for the classification of all 51 states into control, treated, and excluded category. The control states include 30 states where payday lending is permissible during the period 2001-2016 (hereafter referred to as 'period of interest' or 'study period'). The treated states include the state of New Hampshire (the state of our primary interest) plus the states of Arizona, Arkansas, and Montana (used for supplemental 
analyses). The list of excluded states includes the remaining 17 states, which were removed from our analysis mainly due to the existence of payday lending restrictions during the study period (either fully or partially).

We substantiate Table 2 by providing additional state-specific details on the history of payday lending regulations in Appendix Table A.1 and the respective sources in Appendix Table A.3. The state-specific payday lending information has been collected from a thorough and comprehensive review of annual state legislations in the HeinOnline and Lexis Advance databases in combination with the existing payday literature and online media evidence. To the best of our knowledge, this is the first study to provide a detailed overview of the history of payday lending regulations for all 51 states in the US throughout time. This may benefit future researchers interested in evaluating the effects of state-level payday legislation by exploiting state and time variation in payday lending regulations that can be dated back to as far as the early 1990s, and sometimes earlier.

Figure 1 provides the US map illustrating the status of payday lending regulation across all states as of the end of our study period. While 16 states completely restrict payday lending activities, three states (Oregon, Colorado, and Maine) allow the operation of the business under certain restrictions. The remaining 32 states (shaded in green) permit payday lending business.

Figure 2 provides a cartographic representation of the Table 1 information. The treated states are shaded in dots, the control states are shaded in green, and the excluded states are shaded in blue. The control group includes the 30 states where payday lending is permissible, at least since the first year of our study period, that is, 2001. It's important to note that some states in the control group may have authorized and/or initiated the regulation of payday lending activities during years within our study period. However, there is evidence that confirms the presence of payday lending business prior to the first year of our study period. ${ }^{5}$ These states (along with effective authorization/ regulation years) include Alabama (2003), Florida (2001), Idaho (2003), Illinois (2005), Indiana (2002), Michigan (2005), Nevada (2005), North Dakota (2001), Oklahoma (2003), Rhode Island (2001), and Wisconsin (2010).

In addition, some states in our control group have attempted to tighten their existing pay-

\footnotetext{
${ }^{5}$ For a number of states, we treat the year when a state first enacted legislation to regulate the payday lending business as the authorization year. This is because regulating payday lending business appears to imply legalizing payday activities in addition to providing state-specific guidelines for payday services such as licensing requirements for lenders, maximum loanable amount and other borrowing requirements, restriction on lenders right to pursue criminal charges against defaulting borrowers. See Appendix Table A.1 for further details.
} 
Table 2: Treated States and Selection of Control Units

\begin{tabular}{|c|c|c|}
\hline Category & States & Reason for Categorization \\
\hline Control States (30) & $\begin{array}{l}\text { Alabama (AL) } \\
\text { California (CA) } \\
\text { Delaware (DE) } \\
\text { Florida (FL) } \\
\text { Hawaii (HI) } \\
\text { Idaho (ID) } \\
\text { Illinois (IL) } \\
\text { Indiana (IN) } \\
\text { Iowa (IA) } \\
\text { Kansas (KS) } \\
\text { Kentucky (KY) } \\
\text { Louisiana (LA) } \\
\text { Michigan (MI) } \\
\text { Minnesota (MN) } \\
\text { Mississippi (MS) } \\
\text { Missouri (MO) } \\
\text { Nebraska (NE) } \\
\text { Nevada (NV) } \\
\text { New Mexico (NM) } \\
\text { North Dakota (ND) } \\
\text { Ohio (OH) } \\
\text { Oklahoma (OK) } \\
\text { Rhode Island (RI) } \\
\text { South Carolina (SC) } \\
\text { Tennessee (TN) } \\
\text { Texas (TX) } \\
\text { Utah (UT) } \\
\text { Washington (WA) } \\
\text { Wisconsin (WI) } \\
\text { Wyoming (WY) }\end{array}$ & $\begin{array}{l}\text { Permitted; authorized and regulated in } 2003 \\
\text { Permitted; authorized and regulated in } 1996 \\
\text { Permitted; authorized and regulated since } 1987 \\
\text { Permitted; regulated in } 2001 \\
\text { Permitted; regulated in } 1999 \\
\text { Permitted; regulated in } 2003 \\
\text { Permitted; regulated in } 2005 \\
\text { Permitted; authorized and regulated in } 2002 \\
\text { Permitted; authorized in } 1995 \\
\text { Permitted; authorized and regulated in } 1993 \\
\text { Permitted; authorized and regulated in } 1998 \\
\text { Permitted; authorized and regulated in } 2000 \\
\text { Permitted; authorized and regulated in } 2005 \\
\text { Permitted; authorized and regulated in } 1995 \\
\text { Permitted; authorized and regulated in } 1998 \\
\text { Permitted; authorized and regulated in } 1991 \\
\text { Permitted; authorized and regulated in } 1994 \\
\text { Permitted; regulated in } 2005 \\
\text { Permitted; regulated in } 1955 \\
\text { Permitted; authorized and regulated in } 2001 \\
\text { Permitted; authorized and regulated in } 1995 \\
\text { Permitted; authorized and regulated in } 2003 \\
\text { Permitted; authorized and regulated in } 2001 \\
\text { Permitted; authorized and regulated in } 1998 \\
\text { Permitted; authorized and regulated in } 1997 \\
\text { Permitted; authorized and regulated in } 1997 \\
\text { Permitted; regulated in } 1999 \\
\text { Permitted; authorized and regulated in } 1995 \\
\text { Permitted; regulated in } 2010 \\
\text { Permitted; regulated in } 1996\end{array}$ \\
\hline Treated States (4) & $\begin{array}{l}\text { Arizona (AZ) } \\
\text { Arkansas (AR) } \\
\text { New Hampshire (NH) } \\
\text { Montana (MT) }\end{array}$ & $\begin{array}{l}\text { Restricted in } 2010 \\
\text { Restricted in } 2011 \\
\text { Restricted in } 2009 \\
\text { Restricted in } 2010\end{array}$ \\
\hline Excluded States (17) & $\begin{array}{l}\text { Alaska (AK) } \\
\text { Colorado (CO) } \\
\text { Connecticut (CT) } \\
\text { District of Columbia (DC) } \\
\text { Georgia (GA) } \\
\text { Maine (ME) } \\
\text { Maryland (MD) } \\
\text { Massachusetts (MA) } \\
\text { New Jersey (NJ) } \\
\text { New York (NY) } \\
\text { North Carolina (NC) } \\
\text { Oregon (OR) } \\
\text { Pennsylvania (PA) } \\
\text { South Dakota (SD) } \\
\text { Vermont (VT) } \\
\text { Virginia (VA) } \\
\text { West Virginia }\end{array}$ & $\begin{array}{l}\text { Payday lending was illegal until } 2005 \\
\text { Imposed partial restrictions in } 2010 \\
\text { Restricted since } 1949 \\
\text { Restricted in } 2007 \text {; non-availability of data } \\
\text { Restricted in } 2004 \\
\text { Permitted but restricted } \\
\text { Restricted under usury law } \\
\text { Restricted under small loan act } \\
\text { Restricted under consumer loan act } \\
\text { Restricted under state banking law } \\
\text { Restricted in } 2001 \text {; banned in } 2005 \\
\text { Restricted partially in } 2007 \\
\text { Restricted under discount company act } \\
\text { Restricted in } 2016 \\
\text { Restricted under small loan law } \\
\text { Permitted; unauthorized until } 2002 \\
\text { Restricted under small loan act }\end{array}$ \\
\hline
\end{tabular}

Notes: In Appendix Table A.1 we give a highly-detailed review of payday restrictions in each state. 
Figure 1: Classification of US States by Payday Lending

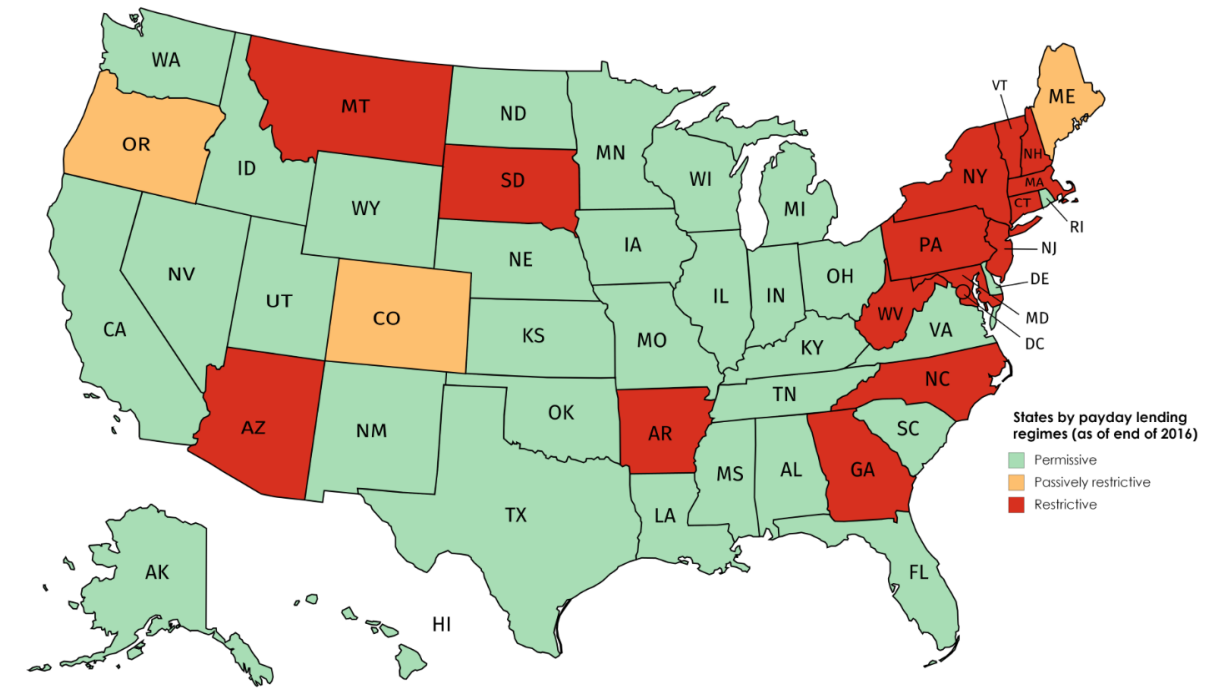

Figure 2: Classification of US States into Treatment-, Control-, and Excluded States

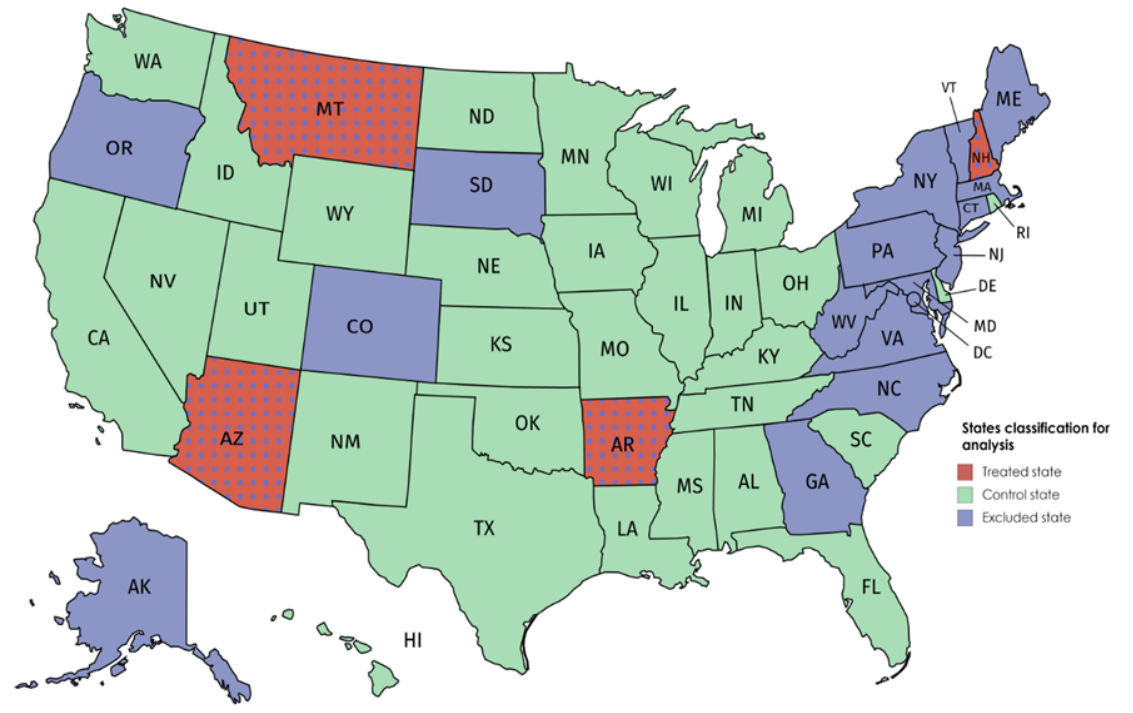

Notes: Virginia legalized payday lending in 2002, which is only one year into our study period. Our main results are unchanged if we include Virginia as a control state and run the analysis for 2002-2016. We prefer, however, eliminating Virginia and running the analysis from 2001 - 2016 in order to maximize the number of observations for other states. South Dakota passed an interest rate cap of 36\% APR in 2016. Hence, because South Dakota received the "treatment" we exclude them from the list of control states because it is conceptually possible that even the consideration of passing a payday lending ban could have altered consumer behavior. Nonetheless, for the sake of robustness, we checked whether the inclusion of South Dakota affects our results; it does not. Nominally, Maine is only "partially" restrictive, but the industry is effectively banned there, including online payday lending. See Section 1 for details. 
day lending regulation in the recent past in order to reduce the prevalence of predatory lending behavior from lenders. A few interesting examples include the states of Ohio and Washington. Ohio enacted the short-term lender law in 2008 that restricted lenders from making loans using the electronic media among other requirements. However, the state's payday lenders were able to bypass the legislation by registering as credit service providers who are eligible to run their payday lending business under the states Mortgage Lending Act and the Small Loan Act. Washington passed a bill in 2009 (to be effective in 2010) that limited the maximum loanable amount and imposed a cap on the number of loans an individual can borrow in a year in addition to some other provisions (see Cuffe and Gibbs (2017) for details).

Nonetheless, despite the legislative efforts adopted by some states, there is substantial evidence that shows an unhindered presence of payday lending activities in the states selected in our control group. Accordingly, we broadly classify the control states as the 'permissible' group, that is, those states that have not unconditionally restricted payday lending during the period of our interest.

With respect to the treated states, New Hampshire effectively restricted payday lending in January 2009 by imposing an annual interest rate cap of $36 \%$ on all small loans, which includes payday loans. There are two principal reasons why we make New Hampshire the main focus of our research. First, New Hampshire enacted restriction on payday lending in the middle of our study period. This ensures that we have a sufficient number of pre- as well as postimplementation periods. Second and more importantly, New Hampshire shares its boundary with states (and Quebec) where payday lending is already restricted. This reduces the possibility of New Hampshire residents crossing state lines to borrow from regions where payday loans are accessible. This is a real possibility. In fact, evidence from Pew (2012) and Melzer and Morgan (2015) shows that residents of Massachusetts, a payday-banning state, crossing into New Hampshire to get access to payday loans. Hence, this unique geographical feautre of New Hampshire allows us to estimate the true impact of a payday loan ban.

The three other states that we consider for additional supportive evidence include Arizona, Arkansas, and Montana. To provide a brief legislative background on how these states prohibited payday lending, Arizona enforced ban on payday lending in 2010 by allowing a previously enacted law (effective in 2000) to expire. The law exempted payday lenders from the existing $36 \%$ APR cap on small loans. Arkansas restricted payday lending in 2011 by repealing its check 
cashers act that allowed payday lenders to operate within the state. Montana prohibited payday lending through a ballot initiative, which allowed the states voters to put a $36 \%$ APR cap on all loans.

We exclude 17 states from our analysis. We drop 14 states due to restrictions on payday lending activities that were imposed either prior to or within our study period. We drop Alaska, District of Columbia, and Virginia for alternative reasons. Although District of Columbia could have been a potentially treated state in our analysis, we drop the state due to missing data issues, especially with respect to the outcomes of interest such as bankruptcy filings. Although payday lending is permitted in the states of Alaska and Virginia, the business was not legal until the same was authorized in the regions in the years 2005 and 2002, respectively. Additionally, we did not find any evidence on the presence of payday lending business in the two states prior to the respective authorization years. Nevertheless, to be sure, our results still hold if we include Virginia by restricting our study period to 2002-2016. However, we prefer using 2001-2016 as our study period to maximize the pre-treatment information.

\section{Section 4: Empirical Approach}

As mentioned above, we pursue a sequence of research questions. First, we test whether payday lending fell in the recently-banning states. Then, we test whether there was a change in bankruptcy rates, formal or informal. We then consider alternative sources of short-term, highcost financing, e.g., credit card cash advances, pawnshop loans, etc. To implement this sequence of testing, we employ a twofold empirical strategy. First, we run difference-in-differences (DID) regressions. Second, we use the synthetic control method (SCM) for the continuous series, e.g., number of payday lending establishments, bankruptcies, and delinquency rates. In this section, we describe our variables and data, as well as a detailed explanation of the DID and SCM methodologies applied to our research questions.

\subsection{Variables and Data Sources}

To examine whether interest rate caps are an effective payday ban, we analyze data from three sources. First, we use survey evidence from the FDIC's National Survey of Unbanked and Underbanked Households, which asks about payday loan usage. This survey is a biennial (odd- 
numbered years, 2009 - 2017), nationally-representative survey that is administered as a CPS supplement. We do not use the 2017 survey since it is beyond the time period of our study. Second, we use survey evidence from FINRA's National Financial Capability Study (detailed below), which also asks about payday loan usage. Finally, we look at the number of payday lenders as identified by the US Census Bureau's County Business Pattern data using the North American Industry Classification System (NAICS) codes. Payday lending is classified under NAICS code 522390, along with other non-bank credit intermediation services.

For formal bankruptcy, we collect quarterly non-business bankruptcy filings by state-year and state from the US courts caseload statistics tables. In addition, we separately look at three different categories of non-business bankruptcy filings: total, Chapter 7, and Chapter 13. Of the three existing individual (non-business) bankruptcy categories, the Chapter 7 classification is the most common form of bankruptcy filings in the US, through which an agent can liquidate a filer's assets to partially or fully repay his existing debts. In the event that the liquidation of assets fails to cover all debts, the remaining unpaid debt is discharged. Unlike Chapter 7, Chapter 13 filers (also known as the wage earners plan) are not required to liquidate their assets. Instead, individuals need to have stable earnings in order to develop a proposal for a future repayment plan that ranges from 3 to 5 years (Hynes 2012). We supplement these state-level bankruptcy rates with FINRA survey data on a population of payday borrowers (see below).

For informal bankruptcy, we use state-year percentages of delinquencies on credit card, mortgage, auto, and student loans. These estimates are obtained from the Center of Microeconomic Data (Federal Reserve Bank of New York), which provides state-level household debt statistics from the years 2003 until 2017. All of the delinquency series are annual in frequency.

Regarding alternative sources of financing, we analyze FINRA's National Financial Capability Survey, which is a nationally-representative, triennial survey that is run by FINRA in consultation with the US Department of the Treasury. The survey was administered three times: 2009, 2012, and 2015. The survey instruments that we are interested in are the following: payday loan usage, bank overdrafting, credit card over-limit charges, credit card cash advances, and pawn shop usage. What's more, the survey also asks about the following: bankruptcy, late fees on credit card bills, general difficulty paying bills, and overall financial condition. Across all three instantiations of the survey, there are a total of over 54,000 respondents. We use the survey in three ways. First, we use it, in part, to confirm that interest rate caps are an effective 
payday lending ban. Second, we use it to corroborate our bankruptcy findings from the statelevel synthetic control evidence. Finally, we use it to study the extent to which payday lending bans push consumers into alternative sources of high-interest credit. Another form of high-cost financing is crime, e.g., theft (see Morse (2011) and Xu (2016)). Hence, we also test whether payday lending bans led to an increase in property crime and robberies. These latter data come from the FBI's Uniform Crime Reporting statistics.

In many of our analyses, we consider a wide range of state-level controls to ensure the robustness of our estimates. With respect to demographics, we include state-year proportion of the population who are female (sex), White (race), Hispanic (ethnicity) and adult (18 years and above). The social and political characteristics of the state may affect consumers' financial condition. Accordingly, we control for the following: high-school graduation and college attendance; binary indicators for medical marijuana law and democratic governor; incidence of property crime; total arrests; and drug and alcohol-induced death.

To account for state-level economic conditions, we control for the following variables: seasonallyadjusted unemployment rate, real GDP per capita, poverty rate, Supplemental Nutrition Assistance Program (SNAP) take-up rate, Medicaid recipience rate, and house price index. We also include financial institution-based indicators, including the following: number of commercial banks (CB) and savings institutions (SI) per 100,000 population; total individual as well as credit card loans per capita (from CB and SI); total liabilities-assets ratio (in CB and SI); number of credit intermediation institutions; number of employed individuals in those establishments per 100,000 population. In the Table A.2 of the Appendix, we present pre-payday lending restriction sample mean (or proportion) of all variables used in our analysis for the control states and for each treated state (New Hampshire, Arizona, Arkansas, and Montana). In the same table, we also indicate the statistical significance of the difference in mean (using t-statistic values) of all the variables for each treated states and respective control states.

When analyzing survey data, we are able to include individual-level covariates such as race, gender, education, and age. When possible, we control for employment situation, e.g., employed, unemployed, and household size. 


\subsection{Difference-In-Differences Estimation}

For each of our three research questions we employ difference-in-differences (DID) regressions. The control (untreated) states in the DID regressions include all the states classified under the same category in Table 2. We also include all of the aforementhioned state-level covariates when analyzing state-level bankruptcy and delinquency data; and we include individual-level covariates when analyzing the survey data. More formally, we estimate the following:

$$
Y_{i s t}=\rho_{0}+\rho_{1}(\mathrm{BAN})_{s t}+\rho_{2} X_{i s t}+\rho_{3} Z_{s t}+\gamma_{s}+\lambda_{t}+\epsilon_{i s t}
$$

where $Y_{\text {ist }}$ represents the aforesaid binary outcomes (or bankruptcy or delinquency rates), and $\mathrm{BAN}_{s t}$ is a binary indicator for having a payday lending restriction in state $s$ at time $t$. $X_{i s t}$ and $Z_{s t}$ represent vectors of individual and state-level characteristics, respectively. State fixed effects are denoted by $\gamma_{s}$. Time fixed effects are denoted as $\lambda_{t}$. The parameter $\rho_{1}$ is the estimated measure of the relationship between payday restrictions and the outcomes of interest. ${ }^{6}$ For binary outcomes, e.g., the FDIC and FINRA survey instruments, the parameter $\rho_{1}$ has the interpretation of a marginal effect. For the sake of robustness, all binary outcomes are estimated by a LSDV-LPM model as well as a probit specification. We cluster all standard errors at the state-level.

\subsection{Synthetic Control Method Estimation}

To assess the causal impact of payday lending restrictions on the incidence of personal bankruptcy filings and delinquencies, we employ the synthetic control method (SCM) formulated by Abadie et al. (2010). ${ }^{7}$ In the context of our study, the SCM implements a data-driven process to illustrate a counterfactual post-payday lending restriction path for New Hampshire. More specifically, this counterfactual is represented by a synthetic New Hampshire, which is optimally generated from a pool of pre-specified 'donor pool' of control states.

\footnotetext{
${ }^{6}$ We include a wide-range of relevant state-level demographic, social (crime, political, substance use), economic, and banking sector related covariates included in our regression to minimize omitted variable biases arising from unobserved heterogeneities. However, due to collinearity issues, we avoid inclusion of state-specific linear time trends in our DID analysis.

${ }^{7}$ We use Stata version of the Synth command developed by Abadie et al. (2010) to estimate SCM (information accessed from http://fmwww.bc.edu/RePEc/bocode/s/synth.html; retrieved on March 20, 2018). For robustness, we also estimate fully nested optimization models (using the nested and allopt option) that search the optimal convex combination of the control units from all possible values of $\mathrm{V}$ and $\mathrm{W}$. The results are markedly similar to the default estimates reported in our main analysis.
} 
To illustrate the SCM strategy, let there be a sample of $I+1$ units (represented by the treated and control states) indexed by $i$, where unit $i=0$ is the treated state (New Hampshire in our case) and all other potential comparison states are denoted by $i=(1, I)$. We define $Y 0$ as a $(k \times 1)$ vector that incorporates pre-intervention (2001-2008) values of the dependent variable and $(k-1)$ relevant covariates that are predictive of the outcome of interest. Let $Y 1$ be a $(k \times I)$ matrix that includes the values of the same pre-intervention variables for the each $i$ th unit in the donor pool. The SCM assigns non-negative weights to identify a convex combination of the $I$ control states, which is expected to mimic the treated unit during the pre-intervention period. This is achieved by minimizing the difference between pre-treatment characteristics of the treated and the synthetic control. The weights $w_{i}$ are selected such that $\left(\sum_{i=1}^{I} w_{i}=1\right)$. More formally, the SCM selects the optimal of combination of $w_{i}$, represented by vector $W^{*}$, which solves the following constrained minimization problem:

$$
\begin{array}{r}
W^{*}=\underset{W}{\arg \min }\left(\mathbf{Y}_{\mathbf{0}}-\mathbf{Y}_{\mathbf{1}} \mathbf{W}\right)^{\prime} \mathbf{V}\left(\mathbf{Y}_{\mathbf{0}}-\mathbf{Y}_{\mathbf{1}} \mathbf{W}\right) \\
\text { s.t. } \sum_{i=1}^{I} w_{i}=1 ; w_{i} \geq 0 \forall i=(1, \ldots, I)
\end{array}
$$

where $\mathbf{V}$ is a positive definite matrix. The estimation of treatment effects using the SCM allows us to compute a difference-in-differences (DD) estimate. To calculate our DD estimate, we employ a strategy similar to the approach adopted by Bohn, Lofstrom, and Raphael (2014). That is, we assume Depvar $r_{p r e}^{N H}$ and Depvar pre to be the average pre-intervention values (i.e. for the period 2001-2008) of the outcome variable for New Hampshire and its synthetic control respectively. Further, we define Depvar post and Depvar post ${ }_{\text {post }}^{\text {synt }}$ as the post-payday lending restriction (period spanning between 2009 and 2016) average of the outcome variable for New Hampshire and its synthetic control, respectively. Using the defined values, the DD estimate for New Hampshire is:

$$
D D_{N H}=\left(\text { Depvar }_{\text {post }}^{N H}-\text { Depvar }_{\text {post }}^{\text {synth }}\right)-\left(\text { Depvar }_{\text {pre }}^{N H}-\text { Depvar }_{\text {pre }}^{\text {synth }}\right)
$$

We formally test the statistical significance of the DD estimate of interest by performing the permutation test recommended by Abadie et al. (2010). This is done by performing a placebo analysis. More specifically, considering New Hampshire's passage year of payday lending 
restriction as the treatment year, we identify synthetic comparisons for each state included in the donor pool for New Hampshire to calculate placebo DD estimates of the untreated states. In other words, the program iteratively runs the synthetic control method on each of the control states in the donor pool (each time excluding the treated state, e.g., New Hampshire). This will generate a sampling distribution for $D D_{N H}$, from which we are able to calculate a p-value, and therefore perform tests of statistical inference (see Bohn et al. (2014) for details).

Based on the sample of 31 states (New Hampshire state plus 30 control states), the cumulative density function of the DD estimate obtained from (4.3) gives us the probability value of a onetailed test of the 'debt trap' hypothesis that $D D_{N H}<0$. As noted earlier, we repeat the above empirical analysis for the states of Arkansas, Arizona, and Montana. For each of the three additional states, we consider the same group of control states employed for New Hampshire. ${ }^{8}$

\section{Section 5: Research Questions and Results}

In this section we present the results of our empirical approach. First, we test whether interest rate caps have their intended effect of limiting payday lending. This is important because there have been instances when states were able to circumvent the legislation, e.g., Ohio, North Carolina (see Bhutta (2014)). We show strong evidence that the interest rate caps are indeed an effective payday lending ban. Then, we test whether the effective ban affected bankruptcy, including informal bankruptcies. Finally, we test whether the ban pushed consumers into pawnshop loans or committing petty crime.

\subsection{Are Interest Rate Caps an Effective Payday Ban?}

Rather than an outright ban on payday loans, many states have opted to impose an interest rate ceiling, frequently set at $36 \%$ APR. The rationale is that if payday lenders cant afford to make loans at that price, then perhaps they shouldn't be making loans at all. To give a rough idea, payday loans are typically two weeks in duration, and priced at $\$ 15$ for every $\$ 100$ borrowed, which translates to an APR of $390 \%$. At $36 \%$ APR, the same payday loan would need to be

\footnotetext{
${ }^{8}$ Building on the SCM concept, Galiani and Quistorff (2017) developed the synth_runner package in Stata that can estimate average treatment effects of an intervention in a case where multiple treated units receive treatment at different time points. As we are interested in exploiting state-specific heterogeneity in the effects of payday lending restrictions, we do not employ this new approach. Instead, we separately estimate SCM for each of the treated states to check the consistency of the treatment effects on the main outcome of interest i.e. bankruptcy filing rate.
} 
priced at $\$ 1.39$ for every $\$ 100$ borrowed.

Flannery and Samolyk (2005) show that such high APRs, e.g., 390\%, are indeed justified by the costs of the industry (but cf. DeYoung and Phillips (2009)). Part of the reason for the high APR is the necessary cross-subsidization in a market plagued by asymmetric information. Dobbie and Skiba (2013) find that $19 \%$ of initial payday loans go into default. The adverse selection that Dobbie and Skiba find in their data is even worse in the online payday lending market: Li, Mumford, and Tobias (2012) find that the default rate from an online lender was $28 \%$; Rigbi (2013) finds a default rate of $19.4 \%$.

Payday lenders are not able to stay in business charging 36\% APR. Zinman (2010) finds that payday loan usage in Oregon fell after it imposed a 36\% cap. Bhutta (2014) finds that payday lending legislation-most often in the form of an interest rate cap-does indeed have bite. He shows that the concentration of payday lenders is remarkably higher in states that have less stringent payday lending restrictions. This finding is confirmed by Barth et al. (2016).

From the supply side, we test whether the number of payday lenders decreases as a result of the payday loan restrictions. Our measure of the number of payday lending storefronts is the number of establishments of NAICS 522390, 'other activities related to credit intermediation'. This isn't a perfect measure since it also includes other non-bank credit intermediation services. From the demand side, we test whether payday loan usage dropped among consumers in the states that restricted payday lending relative to the states that did not. Our measure of payday loan usage comes from two sources: the FDICs National Survey of Unbanked and Underbanked Households, a biennial survey that is administered as a supplement to the Current Population Survey; and FINRAs National Financial Capability Survey, which is administered on a triennial basis.

To further solidify these results we retrieved (from EDGAR) the 2011 10-K from Advance America, Cash Advance Centers, Inc., which is the nationwide market leader in the payday lending industry. On page 18 it states "[l]egislation was adopted in New Hampshire in 2008 that effectively prohibits us from offering cash advances to consumers in that state." It goes on to say that all operations were shut down in New Hampshire in February of 2009. Furthermore, it mentions that they ceased operations in Arkansas, Arizona, and Montana as a result of the passage of these states' respective regulations. It is worth pointing out that Advance America does not have any storefronts in any of New Hampshire's neighboring states (see the table on page 
Table 3: OLS DID Analysis of Payday Loan Usage

\begin{tabular}{|c|c|c|c|}
\hline & $\begin{array}{c}\text { FDIC } \\
\text { Payday Loan Use }\end{array}$ & $\begin{array}{c}\text { FINRA } \\
\text { Payday Loan Use }\end{array}$ & $\begin{array}{l}\text { NAICS } 522390 \\
\text { Establishments }\end{array}$ \\
\hline Study period & $2009-2015$ & $2009-2015$ & $2001-2016$ \\
\hline Sample mean & 0.015 & 0.125 & 6.075 \\
\hline Payday loan restriction & $\begin{array}{c}-0.010^{*} \\
(0.006)\end{array}$ & $\begin{array}{c}-0.043^{* *} \\
(0.009)\end{array}$ & $\begin{array}{c}-2.779^{* * *} \\
(0.781)\end{array}$ \\
\hline State fixed effects & $\checkmark$ & $\checkmark$ & $\checkmark$ \\
\hline Year fixed effects & $\checkmark$ & $\checkmark$ & $\checkmark$ \\
\hline State characteristics & $\checkmark$ & & $\checkmark$ \\
\hline Individual characteristics & $\checkmark$ & $\checkmark$ & $\checkmark$ \\
\hline Sample size & 137,593 & 54,571 & 529 \\
\hline \multicolumn{4}{|c|}{$\begin{array}{l}\text { Notes:* is } 10 \% ;{ }^{* *} \text { is } 5 \% \text {; }{ }^{* * *} \text { is } 1 \% \text { significance. The FDIC units is the percentage of people who responded } \\
\text { "yes" to the question 'in the past } 12 \text { months, did you or anyone in your household have a payday loan or payday } \\
\text { advance at a place other than a bank?' The FINRA units is the percentage of people who responded "yes" to } \\
\text { the question 'in the past five years, how many times have to taken out a short term "payday loan?" We collapse } \\
\text { the variable to a binary measure. The FDIC survey is biennial, while FINRA is triennial. The NAICS unit is the } \\
\text { number of establishments per } 100,000 \text { residents. Estimates in the table are interpreted as marginal effects. All } \\
\text { standard errors are cluster-robust, being clustered at the state level. }\end{array}$} \\
\hline
\end{tabular}

10 of the 10-K). This is strong evidence that New Hampshirites were not able to immediately cross state lines to get access to payday loans.

The survey evidence from the demand side is important because it shows that enacting an effective payday lending ban does indeed cut down on payday loan usage. Both the FDICand FINRA survey ask about general payday loan usage; the surveys don't make a distinction between storefront and online loans. Therefore, since both surveys show a statistically significant decrease in payday lending, this is evidence that consumers did not, en masse, migrate to the online payday lending market. Our findings here quantitatively corroborate the qualitative evidence of Pew (2012), which shows that payday loan bans do not push consumers into the online market because consumers are apprehensive about giving their financial information online.

\subsection{Do Payday Lending Bans Mitigate Bankruptcy?}

The goal of putting a cap on interest rates is to eliminate the high APR of payday loans. But this goal is part of a broader desire to protect consumers from a so-called 'debt trap' where consumers take out a high-APR loan, cannot repay it, and they eventually go delinquent on other debts. The cycle ultimately stops at filing for formal bankruptcy protection. Skiba and 
Table 4: OLS DID Analysis of Formal- and Informal Bankruptcy

\begin{tabular}{|c|c|c|c|c|c|c|c|}
\hline \multirow[b]{2}{*}{ Proxies } & \multicolumn{3}{|c|}{ Formal Bankruptcy } & \multicolumn{4}{|c|}{$\begin{array}{c}\text { Informal Bankruptcy } \\
\text { (Delinquencies) }\end{array}$} \\
\hline & $\begin{array}{l}\text { All } \\
\text { filings }\end{array}$ & $\begin{array}{c}\text { Chapter } 7 \\
\text { filings }\end{array}$ & $\begin{array}{l}\text { Chapter } 13 \\
\text { filings }\end{array}$ & $\begin{array}{l}\text { Credit } \\
\text { card }\end{array}$ & $\begin{array}{l}\text { Mortgage } \\
\text { loan }\end{array}$ & $\begin{array}{l}\text { Auto } \\
\text { loan }\end{array}$ & $\begin{array}{l}\text { Student } \\
\text { loan }\end{array}$ \\
\hline Study period & \multicolumn{3}{|c|}{$2001-2016$} & \multicolumn{4}{|c|}{$2003-2016$} \\
\hline Sample mean & 431.300 & 309.578 & 121.401 & 9.051 & 2.931 & 3.283 & 9.185 \\
\hline $\begin{array}{l}\text { Payday loan } \\
\text { restriction }\end{array}$ & $\begin{array}{l}-41.209 \\
(33.394)\end{array}$ & $\begin{array}{l}-25.254 \\
(23.542)\end{array}$ & $\begin{array}{l}-15.952 \\
(17.123)\end{array}$ & $\begin{array}{l}-0.036 \\
(0.387)\end{array}$ & $\begin{array}{l}-0.253 \\
(0.519)\end{array}$ & $\begin{array}{c}0.064 \\
(0.202)\end{array}$ & $\begin{array}{c}0.341 \\
(0.621)\end{array}$ \\
\hline State fixed effects & $\checkmark$ & $\checkmark$ & $\checkmark$ & $\checkmark$ & $\checkmark$ & $\checkmark$ & $\checkmark$ \\
\hline Year fixed effects & $\checkmark$ & $\checkmark$ & $\checkmark$ & $\checkmark$ & $\checkmark$ & $\checkmark$ & $\checkmark$ \\
\hline State characteristics & $\checkmark$ & $\checkmark$ & $\checkmark$ & $\checkmark$ & $\checkmark$ & $\checkmark$ & $\checkmark$ \\
\hline Sample size & \multicolumn{3}{|c|}{529} & \multicolumn{4}{|c|}{462} \\
\hline
\end{tabular}

Notes: These DID regressions were run using annual data for each series. We ran the regressions including all states that banned during the noted time periods, e.g., Georgia in 2004; and we estimated the effect using only those states under main consideration, e.g., AR, AZ, NH, and MT. The results are robust to the inclusion of all banning states. States that banned throughout the entirety of the sample, e.g., NY, were thrown out because they do not add any variation. All variables are expressed as per 100,000 residents. Delinquency units are percentages. All standard errors are cluster-robust, being clustered at the state level.

Tobacman (2011) and Morgan et al. (2012) show that payday lending bans seem to have their intended effect: bankruptcy filings decrease because of a ban.

Informal bankruptcy entails going delinquent on debts, or possibly defaulting on them, without the benefits of formal bankruptcy protection (see Morgan et al. (2012)). Of course, going delinquent (and default) may be a precursor to filing for formal bankruptcy. Zinman (2010), and Morse (2011) show that payday lending access helps consumers meet their other debt obligations. This contrasts with Gathergood et al. (2019), who show that payday lending access worsens debt delinquency. Desai and Elliehausen (2017) find mixed evidence.

We use the states of Arizona, Arkansas, New Hampshire, and Montana as quasi-experimental labs-with a special emphasis on New Hampshire-to test for changes in formal bankruptcy filings (Chapters 7 and 13) and delinquencies (credit card, mortgage, auto loan, and student loan). To be sure, there is overlap in the population of payday borrowers and the population of bankruptcy filers, credit card holders, homeowners, etc. Elliehausen and Lawrence (2008) find that $15 \%$ of payday borrowers have declared bankruptcy in the previous five years. Related to delinquency, about $59 \%$ of payday loan applicants have a general purpose credit card, with approximately $80 \%$ of those having little credit available on their credit cardsor they are maxed out completely (Bhutta et al. (2015)). Approximately $42 \%$ of borrowers who use Advance America, the market 
leader mentioned above, own their home; $32 \%$ have a mortgage; $53 \%$ have an auto loan; and $36 \%$ have at least some college.

It is harder to find data on the complement of the population overlap: what percentage of the population of bankruptcy filers have used a payday loan? But there are some statistics. According to Pew (2012), $4 \%$ of homeowners have used a payday loan; $12 \%$ of those with at least some college have used a payday loan. Admittedly, our analysis of state-level data is both a gift and a curse. While an analysis of state-level data overcomes the potential shortcomings of relying on data from one payday lender (Bhutta et al. (2015)); relying on a threshold-local population (Gathergood et al. (2019)); and the inherent arbitrariness of controlling for statelevel shocks (Bhutta (2014)), it has the principal shortcoming of a mismatch in the populations: the overlap of bankruptcy filers and payday borrowers is likely to be small. Nevertheless, we feel that the analysis is worthwhile, especially when considered in conjunction with the previous findings. To help mitigate this fundamental shortcoming, we filter the abovementioned FINRA survey (Bhutta et al. (2016) does a similar analysis using the FDIC Un/Underbanked Survey) to only those respondents who have taken out a payday loan. We then conduct the analysis on that population-those consumers who are most directly affected by the payday lending ban. We are unaware of any previous studies that use the FINRA survey to study the nexus of bankruptcy and payday lending.

Our first bankruptcy analysis is a set of OLS differences-in-differences regressions on annual state-level bankruptcy and delinquency data (per 100,000 residents) for 34 states between 2001 - 2016. There are four treated states: Arizona, Arkansas, New Hampshire, and Montana. We eliminate the twelve states that banned payday lending throughout the sample period, e.g., New York, because they do not add any variation. We further eliminated other states that banned in the sample period, but are not considered part of the analysis, e.g., Georgia.

The results for formal bankruptcy show a negative sign, which is consistent with Skiba and Tobacman (2011) and Morgan et al. (2012). However, our results are far from significant at conventional levels of significance, a finding that confirms the results of Carter and Skimmyhorn (2017), who suggest that concerns about payday lending-at least among US military-is overblown. The results for delinquencies have mixed signs, but they are all statistically insignificant, a finding that corroborates Bhutta (2014), but seemingly conflict with the findings of Gathergood et al. (2019), who find that payday lending access, measured as loan approval, 
increases delinquencies in the long-run. Gathergood et al. (2019) use UK data. Hence, these conflicting findings yield a potentially fruitful avenue of future research.

\subsubsection{Synthetic Control Evidence from New Hampshire}

The DID analysis above aggregates across the four treated states. In what follows, we present an examination of each of the four states using the synthetic control method (SCM). We present the New Hampshire case in greater detail than the other three states because we believe it is the strongest state-level quasi-experiment available. In order to maximize the pre-treatment fit of the bankruptcy series, we use quarterly data rather than annual data. This gives the SCM estimator more data points to work with. Of course, this comes at the potential cost of overfitting, but this is a trade-off we are willing to make since a quarterly series is still a relatively low frequency.

The synthetic control analysis of New Hampshire shows that bankruptcy rates are largely unaffected by the de facto payday lending ban. This can be seen most clearly in the synthetic control plots. The pre-treatment fit for Chapter 7 bankruptcies is tight. And yet post-treatment there is only a slight increase in bankruptcies vis--vis the synthetic control unit.

Nonetheless, there appears to be evidence that bankruptcy rates increase, and then decrease at a later time. One interpretation of this pattern is that a payday loan ban cuts off access to payday loans, which, in turn causes liquidity-strapped consumers to file for bankruptcy. However, over time, the ban eventually leads to fewer bankruptcies, perhaps because people change their budgeting practices (Pew (2012)). We elaborate on this pattern and its interpretation when we run the ArCo analysis in Section 5.2.2 below. This interpretation is also consistent with the results of Gathergood et al. (2019), who find that payday loan access (measured as loan approval) causes an increase in delinquencies in the short-term, but a decrease in the long run.

Housing and student loan delinquency rates show a statistically significant decline are significant at the $10 \%$ level. However, mortgage delinquency may be confounded by the Great Recession. Agarwal, Gross, and Mazumder (2016) state that the Great Recession led to a general increase in the number of financially constrained consumers, [but] there was not a dramatic shift in the use of payday loans during this period. Furthermore, the weights used to create synthetic New Hampshire for mortgage delinquency are heavily skewed toward one state, Hawaii. 
Hence the comparison may be a poor one because the counterfactual unit reflects the idiosyncrasies of Hawaii.

The student loan delinquency measure shows a tight pre-treatment fit, with the two series diverging modestly immediately after the ban, and then diverging much more afterwards. This finding is consistent with Agarwal et al. (2016), who find that between 2007 and 2013, the payday borrowing rates among those who have at least some college more than doubled, from $3.8 \%$ to $7.7 \%$. Of course it's possible that these borrowers have student loan debt. 
Table 5: Balance Check and Synthetic Control DD Estimates for New Hampshire

\begin{tabular}{|c|c|c|c|c|c|c|}
\hline \multicolumn{7}{|c|}{ Panel a: Balance of New Hampshire and Synthetic New Hampshire } \\
\hline & & Treated & Synthetic & Synthetic & Synthetic & Synthetic \\
\hline & & & $\begin{array}{c}\text { All } \\
\text { bankruptcy }\end{array}$ & $\begin{array}{l}\text { Chapter } 7 \\
\text { bankruptcy }\end{array}$ & $\begin{array}{l}\text { Chapter } 13 \\
\text { bankruptcy }\end{array}$ & - \\
\hline \multirow{3}{*}{\multicolumn{2}{|c|}{$\begin{array}{c}\text { All bankruptcy } \\
\text { Chapter } 7 \\
\text { Chapter } 13\end{array}$}} & 71.766 & 74.918 & - & - & - \\
\hline & & 1.048 & - & 1.140 & - & - \\
\hline & & 1.825 & - & - & 1.968 & - \\
\hline & & & $\begin{array}{l}\text { Credit } \\
\text { card }\end{array}$ & $\begin{array}{l}\text { Mortgage } \\
\text { loan }\end{array}$ & $\begin{array}{l}\text { Auto } \\
\text { loan }\end{array}$ & $\begin{array}{l}\text { Student } \\
\text { loan }\end{array}$ \\
\hline Credi & it card & 7.478 & 7.7491 & - & - & - \\
\hline Mortga & age loan & 1.048 & - & 1.140 & - & - \\
\hline Auto & loan & 1.825 & - & - & 1.968 & - \\
\hline Studer & nt loan & 6.288 & - & - & - & 6.370 \\
\hline \multicolumn{7}{|c|}{ Panel b: Synthetic Control DID Estimates with Weights and Placebo-Based P-Values } \\
\hline $\begin{array}{l}\text { Dependent F } \\
\text { variables }\end{array}$ & $\begin{array}{l}\text { Pre-treatment } \\
\text { NH mean }\end{array}$ & $\begin{array}{c}\text { States with } \\
\text { positive weights }(\%)\end{array}$ & RMPSE & $\begin{array}{c}\text { DD } \\
\text { estimate }\end{array}$ & $\begin{array}{l}\text { Rank of } \\
\text { estimate }\end{array}$ & $\begin{array}{c}\text { p-value: } \\
\text { one-tail } \\
\left(\Delta<\Delta_{N H}\right)\end{array}$ \\
\hline $\begin{array}{l}\text { All } \\
\text { filings }\end{array}$ & 71.767 & $\begin{array}{l}\mathrm{DE}(1.1) ; \mathrm{HI}(74.2) ; \\
\mathrm{NV}(5.8) ; \mathrm{RI}(0.5) ; \\
\mathrm{UT}(1.3) ; \mathrm{WY}(17.2)\end{array}$ & 21.581 & 13.693 & $23 / 31$ & 0.742 \\
\hline $\begin{array}{c}\text { Chapter } 7 \\
\text { filings }\end{array}$ & 61.899 & $\begin{array}{c}\mathrm{DE}(1.7) ; \mathrm{HI}(52) ; \\
\mathrm{RI}(1.2) ; \mathrm{SC}(6.1) ; \\
\mathrm{UT}(4.2) ; \mathrm{WY}(34.8)\end{array}$ & 17.676 & 14.825 & $21 / 31$ & 0.677 \\
\hline $\begin{array}{l}\text { Chapter } 13 \\
\text { filings }\end{array}$ & 9.824 & $\begin{array}{c}\text { DE (2.2); HI (26.4); } \\
\text { IN (3.7); IA (11.4); } \\
\text { RI (5.5); UT (1.5); } \\
\text { WI (8.7); WY (40.8) }\end{array}$ & 4.214 & 3.170 & $21 / 31$ & 0.677 \\
\hline $\begin{array}{l}\text { Credit } \\
\text { card }\end{array}$ & 7.478 & $\begin{array}{l}\mathrm{DE}(0.6) ; \mathrm{HI}(12.8) ; \\
\mathrm{IN}(43.7) ; \mathrm{MN}(4.6) ; \\
\mathrm{RI}(2.9) ; \mathrm{UT}(2.9) ; \\
\mathrm{WY}(32.4)\end{array}$ & 0.900 & 0.956 & $26 / 31$ & 0.839 \\
\hline $\begin{array}{l}\text { Mortgage } \\
\text { loan }\end{array}$ & 1.048 & $\begin{array}{c}\mathrm{DE}(0.8) ; \mathrm{HI}(96.7) \\
\mathrm{UT}(2.5)\end{array}$ & 0.455 & -1.819 & $3 / 31$ & $0.097^{*}$ \\
\hline $\begin{array}{l}\text { Auto } \\
\text { loan }\end{array}$ & 1.825 & $\begin{array}{l}\text { RI (16.8); UT (0.5); } \\
\text { WI (70); WY (12.7) }\end{array}$ & 0.264 & 0.390 & $23 / 31$ & 0.742 \\
\hline $\begin{array}{l}\text { Student } \\
\text { loan }\end{array}$ & 6.288 & $\begin{array}{l}\mathrm{DE}(0.2) ; \mathrm{HI}(24.9) ; \\
\mathrm{IN}(39.8) ; \mathrm{UT}(2.6) ; \\
\mathrm{WI}(15.5) ; \mathrm{WY}(17)\end{array}$ & 0.640 & -1.558 & $2 / 31$ & $0.065^{*}$ \\
\hline
\end{tabular}

Notes:* is $10 \%$; ${ }^{* *}$ is $5 \%$; ** is $1 \%$ significance. RMPSE is the ratio of the mean squared prediction errors. The DD estimate is the calculation of a difference in the differences of the treated unit and its synthetic control unit. The rank of the DD estimate is the ordinal rank of the value vis-a-vis placebo-created DD estimates. The p-value is the rank expressed as a percentage. The one-tailed (negative) test on the DD estimate is a hypothesis test that the estimate is less than zero, i.e., a test of the 'debt trap hypothesis' 
Figure 3: Visual Synthetic Control Results: New Hampshire Formal Bankruptcy
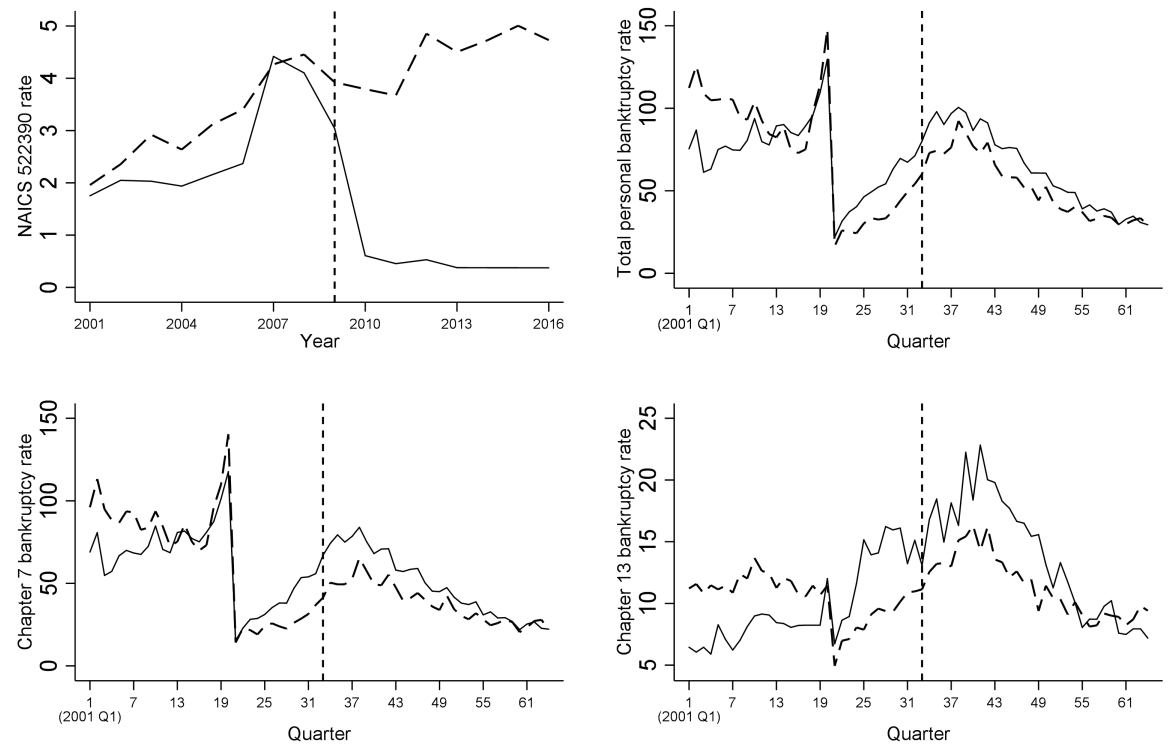

- New Hampshire $\quad-\quad-$ synthetic New Hampshire

Figure 4: Visual Placebo Tests: New Hampshire Formal Bankruptcy
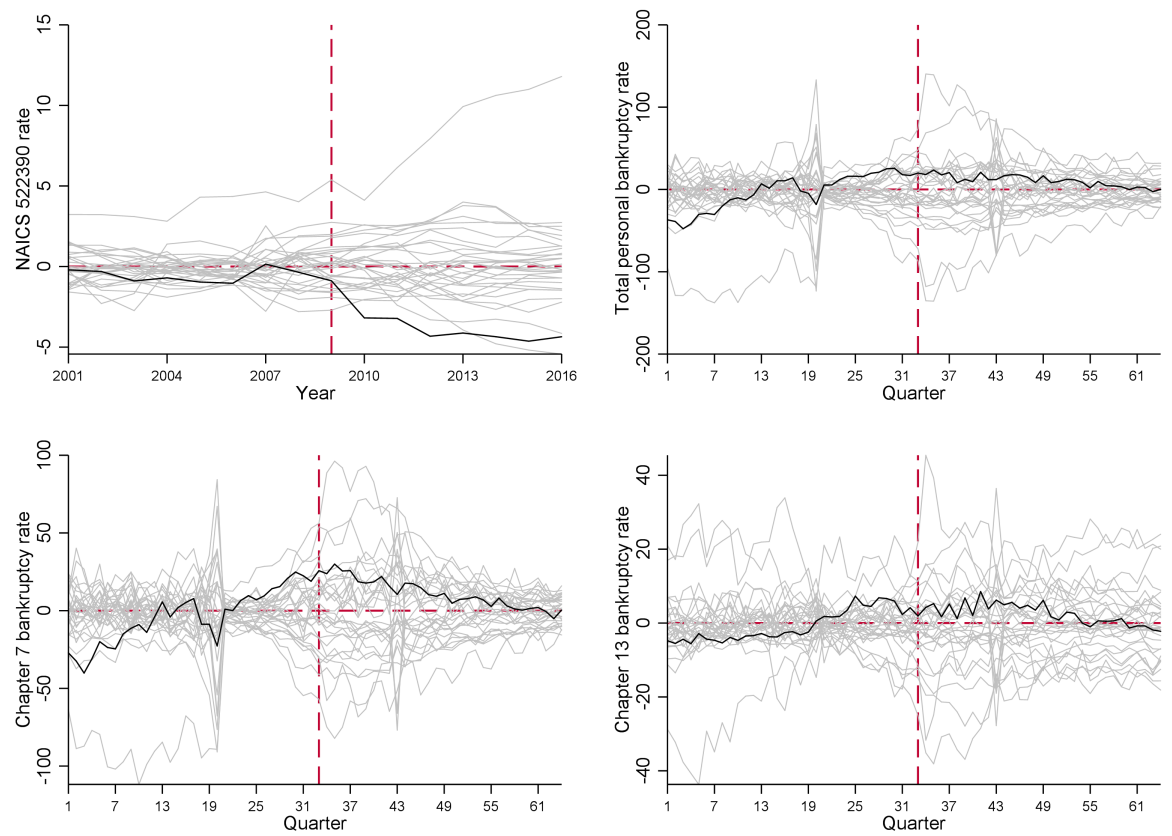

Notes: The dip in the bankruptcy graphs in 2006q1 reflect the Bankruptcy Abuse Prevention and Consumer Protection Act (BAPCA), which was signed into law on 4/20/2005, and went into effect on 10/17/2005. Changes in bankruptcy law are only made at the federal level per the US Constitution. The ultimate goal of the law was to raise the cost of filing for bankruptcy, as well as pushing consumers to file for Chapter 13 rather than Chapter 7. See Lefgen and McIntyre (2009) for details on the BAPCA; see Livshits, MacGee, and Tertilt (2010) for details on the decline of costs of filing for bankruptcy prior to the passage of the BAPCA. We display the NAICS 522390 plots here to show that the interest rate cap permanently banned payday lending in the state, which is helpful for the comparison of the series and their respective synthetic control units over time, especially post-treatment. 
Figure 5: Visual Synthetic Control Results: New Hampshire Informal Bankruptcy
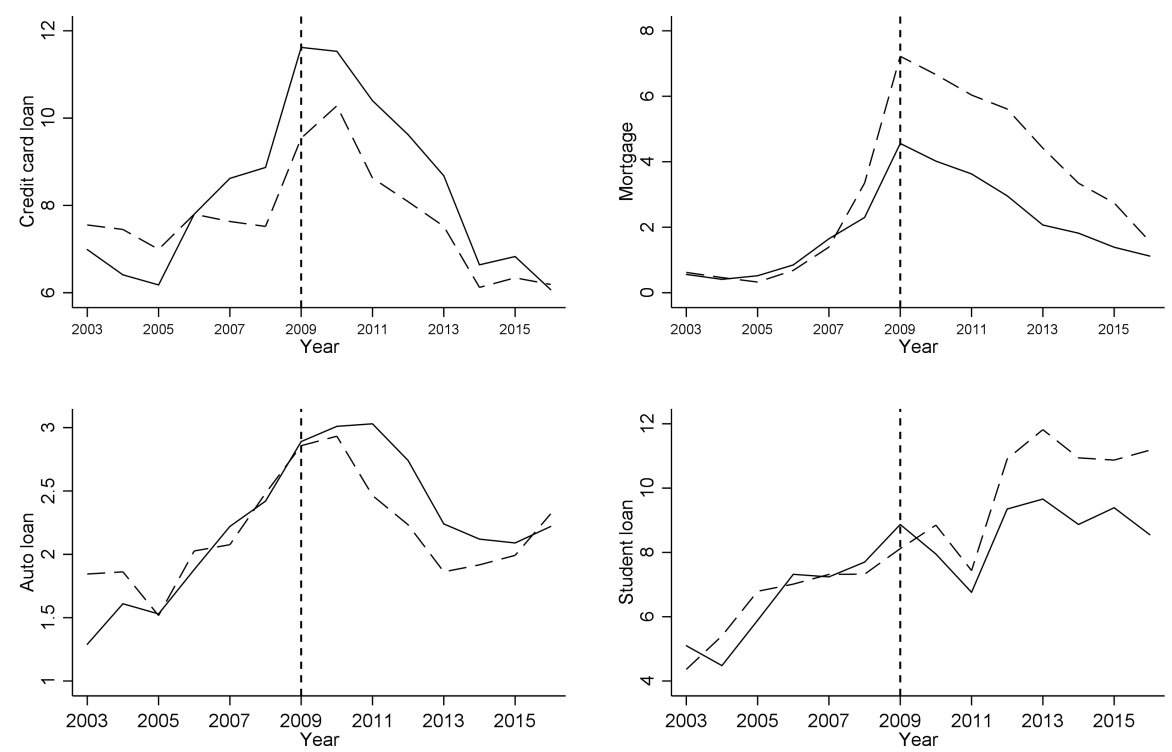

- New Hampshire - - synthetic New Hampshire

Figure 6: Visual Placebo Tests: New Hampshire Informal Bankruptcy
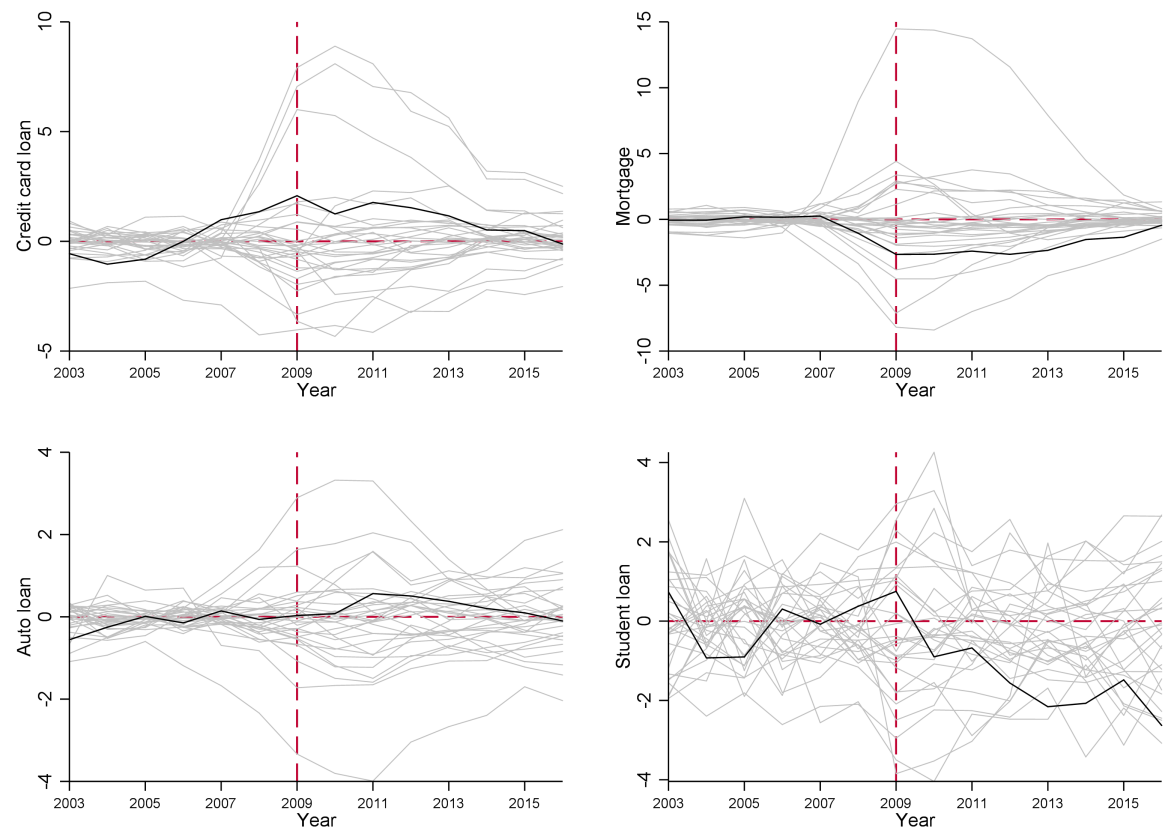

Notes: In the placebo test charts, the bold line represents the difference between the actual series and the synthetic series over time for New Hampshire. The faded gray lines represent the placebos, that is, the gap between the placebo treatment state relative to its synthetic control unit. The program iteratively runs through each of the control states (always leaving out $\mathrm{NH}$ ), and estimates a synthetic control chart. 
Table 6: Panel Unit Root Test and ArCo Estimates

\begin{tabular}{|c|c|c|c|c|c|}
\hline \multicolumn{5}{|c|}{ Panel a: H0: All panels have a unit root } & \multirow[t]{2}{*}{ Panel b: ArCo Estimates } \\
\hline & \multicolumn{2}{|c|}{ No time trends } & \multicolumn{2}{|c|}{ With time trends } & \\
\hline & Unadjusted t & $\begin{array}{c}\text { Adjusted t } \\
\text { (p-value) }\end{array}$ & Unadjusted $\mathrm{t}$ & $\begin{array}{c}\text { Adjusted t } \\
\text { (p-value) }\end{array}$ & $\begin{array}{c}\text { Delta } \\
{[\text { Confidence band }]} \\
(\mathrm{p} \text {-value })\end{array}$ \\
\hline All bankruptcies & -16.455 & $\begin{array}{c}-7.297^{* * *} \\
(0.000)\end{array}$ & -23.525 & $\begin{array}{c}-9.555^{* * *} \\
(0.000)\end{array}$ & $\begin{array}{c}1.312 \\
{[-2.438,5.063]} \\
(0.492)\end{array}$ \\
\hline Chapter 7 & -18.025 & $\begin{array}{c}-8.682^{* * *} \\
(0.000)\end{array}$ & -24.732 & $\begin{array}{c}-10.950^{* * *} \\
(0.000)\end{array}$ & $\begin{array}{c}0.423 \\
{[-3.587,4.432]} \\
(0.836)\end{array}$ \\
\hline Chapter 13 & -12.526 & $\begin{array}{c}-3.378^{* * *} \\
(0.000)\end{array}$ & -17.366 & $\begin{array}{c}-3.810^{* * *} \\
(0.000)\end{array}$ & $\begin{array}{c}0.872 \\
{[-28.539,31.820]} \\
(0.954)\end{array}$ \\
\hline Number of panels & & & & & \\
\hline Number of periods & & & & & \\
\hline
\end{tabular}

Notes: $*$ is $10 \% ; * *$ is $5 \% ; * * *$ is $1 \%$ significance. Panel a contains the results of a Levin, Lin, and Chu (2002) panel unit root test. The null hypothesis that all panels have a unit root is rejected. Panel b contains the treatment effects of the ArCo estimation along with its corresponding confidence bands and p-values.

\subsubsection{Robustness of Synthetic New Hampshire: ArCo Estimation}

A few recent studies have discussed some of the empirical limitations associated with SCM approach that can potentially affect the causal interpretation of the estimates of intervention of interest. The first restriction of SCM arises from its reliance on a convex combination of untreated units to construct the counterfactual. As a result, the SCM estimation assigns nonnegative weights to the treated units peers in the donor pool (summing up to 1; Doudchenko and Imbens (2016); Carvalho, Masini, and Medeiros (2018)). The restrictive nature of this assumption, to some extent, is observed in the dissimilar trends (for the pre-intervention period) in Chapter 13 bankruptcy filing rates for New Hampshire and its synthetic unit (see Figure 3). In addition, the approach used to estimate SCM weights ignores the time-series aspect of the data by considering pre-intervention (time) average of the observed variables for each peer.

To address these concerns, Carvalho et al. (2018) propose a two-step procedure known as the Artificial Counterfactual (ArCo) approach. The first stage of this procedure involves preintervention data to estimate a multi-variate time-series regression model where variables of the treated unit is regressed on the variables of the untreated peers. The linear model is estimated by means of Least Absolute Selection and Shrinkage Operator (LASSO). In the second stage, the ArCo method constructs the counterfactual by extrapolating the estimated model with 
data from the post-implementation period. The treatment effect is given by the average of the difference between actual data (treated unit) and the counterfactual.

It is important to note the causal interpretation of the ArCo estimates relies on two important assumptions. The first assumption requires that peers in the donor pool not to be affected by the treatment of interest. Focusing on the state of New Hampshire due to its locational characteristics (as discussed earlier) combined with our selection of states in the donor pool (see Table 2; where we give the list of states and their classification) ensures that the first assumption is satisfied. The second assumption requires the data to be trend-stationary. This is particularly important as non-stationary data can lead to biases, thereby resulting in inaccurate hypothesis testing. To this end, we additionally perform a panel unit root test proposed by Levin et al. (2002). Based on the results reported in panel a of Table 6, we were able to reject the null hypothesis that all panels have a unit root.

The ArCo results confirm our findings from the synthetic control estimation. ${ }^{9}$ The pretreatment fit of all series is tighter, which is attributable to the relaxation of the SCM assumption that weights be non-negative. By allowing for negative weights, the ArCo program is able to better fit the pre-treatment data, most noticeably in the eight quarters prior to the passage of the payday loan ban. The post-treatment dyanmics of both series largely mimics that of the SCM plots, lending credence to our SCM findings, and their interpretation.

\footnotetext{
${ }^{9}$ We trial multiple ArCo specifications (R package: ArCo) based on examples provided by Fonseca, Masini, Medeiros, and Vasconcelos (2018). The observed trends and results are consistent across all specifications. The graphs and results presented in our study are based on an empirical specification similar to the model estimated in page 97 of the above study. However, we do not bootstrap our confidence intervals and the lag used in the covariance matrix equals 10 .
} 
Figure 7: Visual ArCo Results: New Hampshire Total Non-Business Bankruptcy Filings

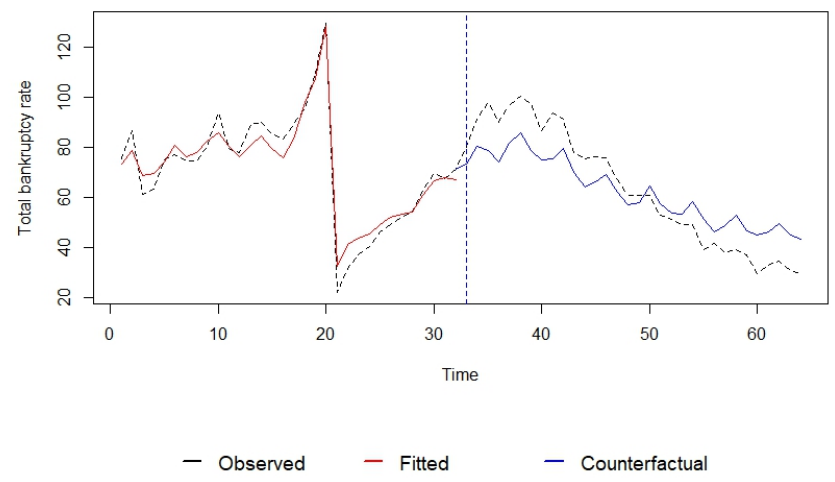

Figure 8: Visual ArCo Results: New Hampshire Chapter 7 Non-Business Bankruptcy Filings

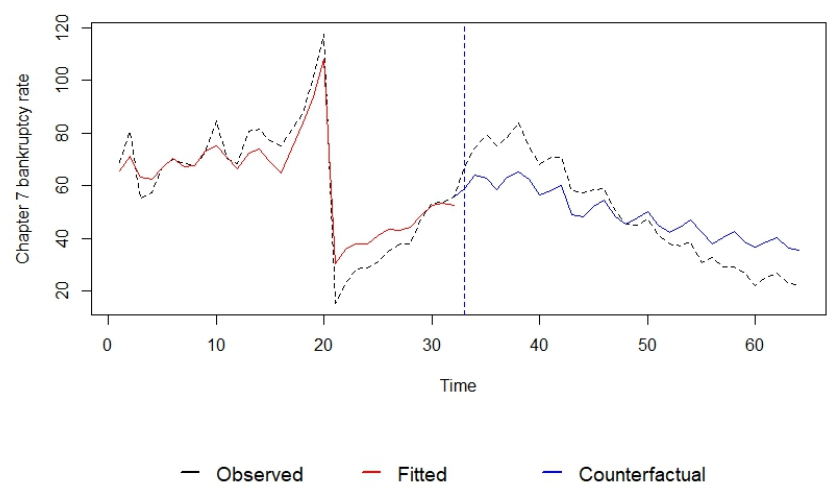

Figure 9: Visual ArCo Results: New Hampshire Chapter 13 Non-Business Bankruptcy Filings

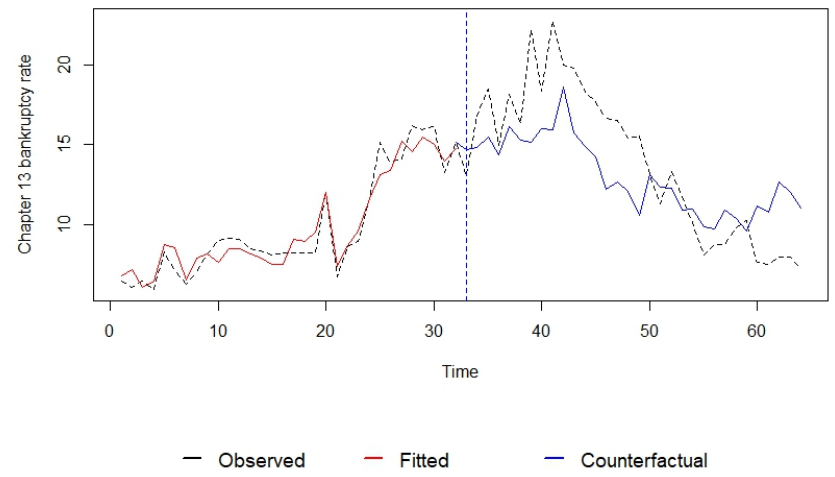

Notes: The dashed line is the actual series; the solid line is the estimated series, that is, the "artificial counterfactual." The fitted series comes from the first stage of the ArCo estimation, which employs LASSO regression in order minimize pre-treatment fit with the actual series. The counterfactual series comes from extrapolating the LASSO regression estimation from the first stage. 


\subsubsection{Synthetic Control Evidence from Arizona, Arkansas, and Montana}

The synthetic control results from the other three states largely confirm the results from New Hampshire. On the whole, Chapter 7 and Chapter 13 bankruptcy rates are unchanged for each of the three states. In fact, the pre-treatment fit for both series for each of the three states is quite tight, which instill confidence in the results, thereby lending credence to the results from New Hampshire.

Nevertheless, there are some nuances to the formal bankruptcy results for these three states. For each of the three states, Chapter 13 bankruptcy filings increase in the quarter immediately after the ban. The Chapter 13 results from Arizona are the most similar to those from New Hampshire in that bankruptcy filings increase vis-a-vis the synthetic control unit, remain higher for some time, and then eventually fall below the synthetic control unit.

Our delinquency results generally show that delinquencies often fall below the synthetic control unit, even after sometimes initially being above it post-ban. Exceptions to this pattern include credit card loan delinquencies in Arizona and student loan delinquencies in Arkansas. On the whole, mortgage delinquencies show a statistically significant decrease as a result of the payday lending bans in Arizona and Montana. These findings seem to conflict with Morse (2011), who shows that payday lending access mitigates home foreclosures. One potential explanation

for the discrepancy in her findings and ours is that she narrowed in on a population that is hit by an adverse financial shock, namely people whose communities were hit by a natural disaster. She cautions, however, that it could be the case that payday loan access helps these people at the expense of payday-loan borrowers who are not hit by a financial shock.

Our results also show that student loan delinquencies exhibit a statistical decrease in Arizona. Further investigation of this effect might be worthwhile. Agarwal et al. (2016) is a promising start down that path. These authors show that payday lending nearly doubled among the population with at least some college education (but not a degree). 


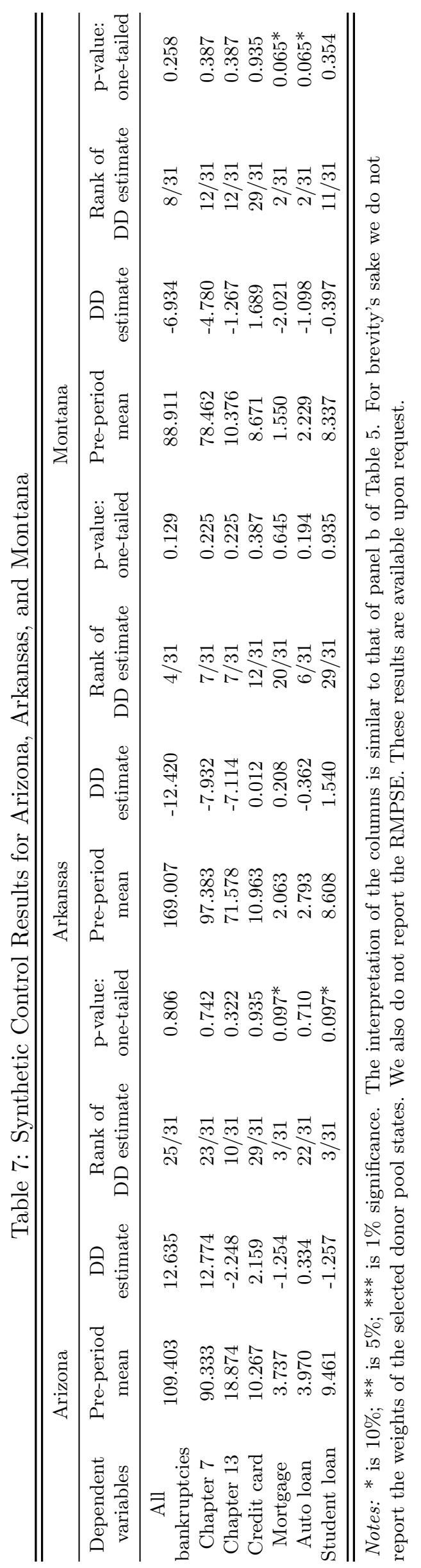


Figure 10: Visual Synthetic Control Results: Other States Formal Bankruptcy
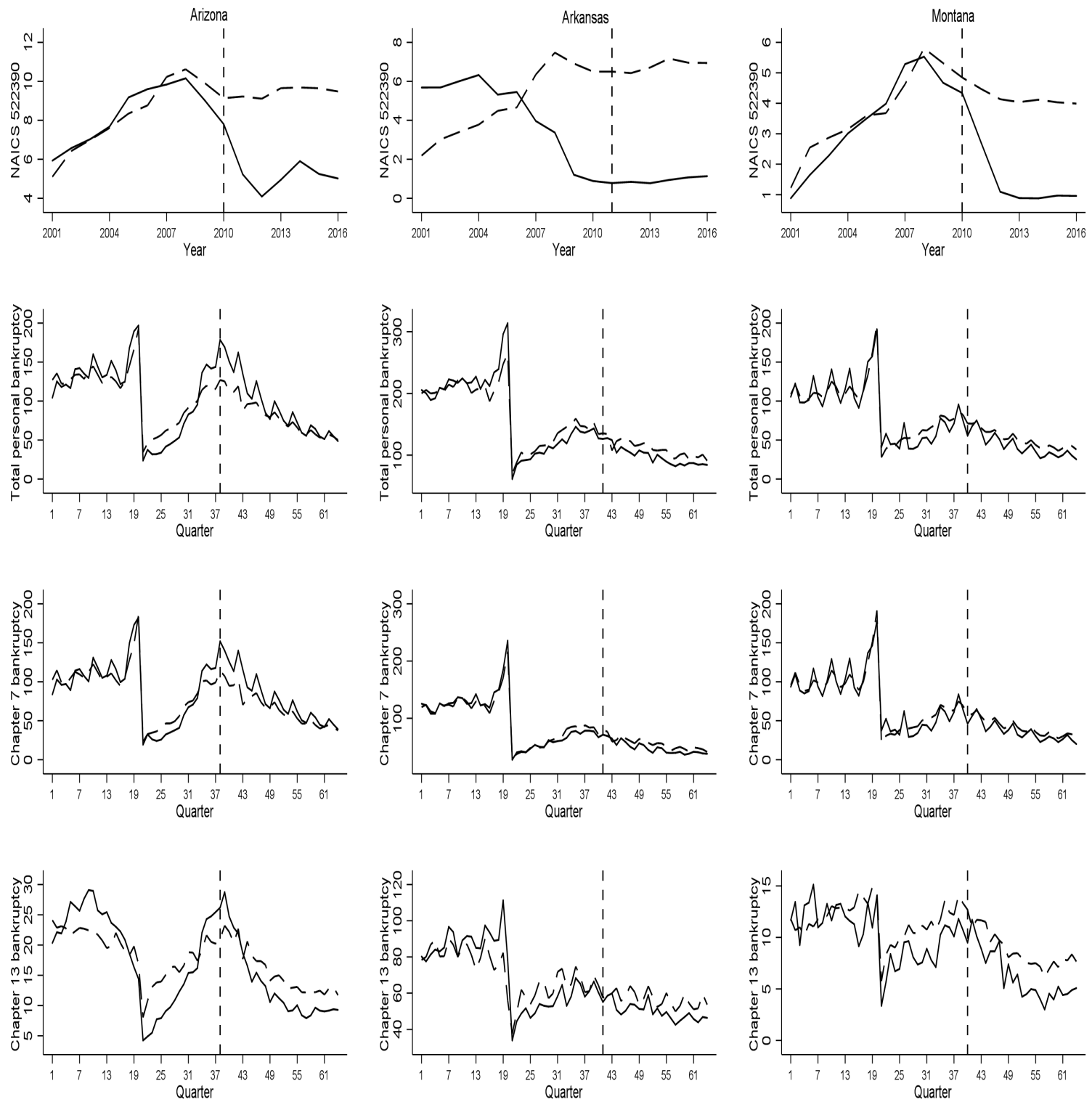

\section{- Treated state -- Synthetic unit}

Notes: The first column is Arizona; the second is Arkansas; the third is Montana. By row, the first is NAICS 522390 establishments. This is included merely for a comparison of what we believe a credible decline should look like in a synthetic control plot. The second row is total personal bankruptcy filings; the third row is Chapter 7 filings; the fourth row is Chapter 13 filings. We display the NAICS 522390 plots here to show that the interest rate cap permanently banned payday lending in the state, which is helpful for the comparison of the series and their respective synthetic control units over time, especially post-treatment. 
Figure 11: Visual Synthetic Control Results: Other States Informal Bankruptcy
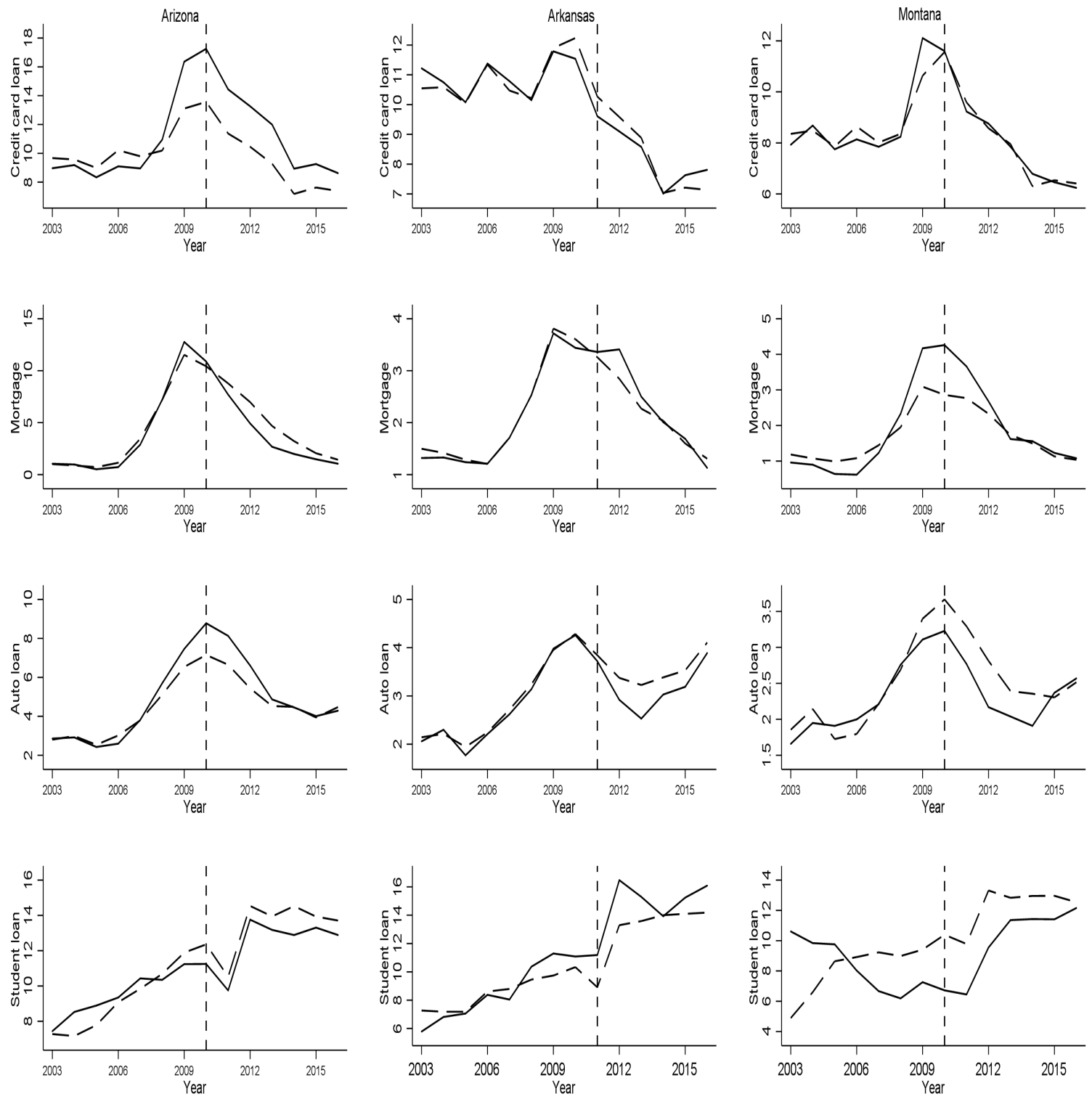

\section{- Treated state - - Synthetic unit}

Notes: The first column is Arizona; the second is Arkansas; the third is Montana. By row, the first is credit card loan delinquency; the second is mortgage delinquency; the third is auto loan delinquency; the fourth is student loan delinquency. 
Table 8: Conditional OLS DID Analysis of Bankruptcy and Financial Well-Being

\begin{tabular}{|c|c|c|c|c|}
\hline \multirow[t]{2}{*}{ Source } & \multicolumn{4}{|c|}{ FINRA National Financial Capability Study } \\
\hline & Bankruptcy & $\begin{array}{l}\text { Late on credit } \\
\text { card payment }\end{array}$ & $\begin{array}{c}\text { Difficulty } \\
\text { paying bills }\end{array}$ & $\begin{array}{c}\text { Overall } \\
\text { financial condition }\end{array}$ \\
\hline Study period & \multicolumn{4}{|c|}{$2009,2012,2015$} \\
\hline Sample mean & 0.085 & 0.474 & 1.89 & 4.333 \\
\hline $\begin{array}{l}\text { Payday loan } \\
\text { restriction }\end{array}$ & $\begin{array}{c}0.061 \\
(0.086)\end{array}$ & $\begin{array}{l}0.124^{* *} \\
(0.054)\end{array}$ & $\begin{array}{l}-0.006 \\
(0.098)\end{array}$ & $\begin{array}{c}0.337 \\
(0.384)\end{array}$ \\
\hline $\begin{array}{l}\text { State fixed effects } \\
\text { Year fixed effects } \\
\text { Individual characteristics }\end{array}$ & $\begin{array}{l}\checkmark \\
\checkmark \\
\checkmark\end{array}$ & $\begin{array}{l}\checkmark \\
\checkmark \\
\checkmark\end{array}$ & $\begin{array}{l}\checkmark \\
\checkmark \\
\checkmark\end{array}$ & $\begin{array}{l}\checkmark \\
\checkmark \\
\checkmark\end{array}$ \\
\hline Sample size & \multicolumn{4}{|c|}{6,821} \\
\hline $\begin{array}{l}\text { Notes: } * \text { is } 10 \% \text {; } * \text { is } 5 \% \text {; } * * \\
\text { out a payday loan in the previo } \\
\text { bankruptcy in the last two year } \\
\text { which of the following describes } \\
\text { late payment. The overall finan } \\
\text { personal financial condition? Th } \\
\text { The difficulty paying bills instr } \\
\text { expenses and pay all your bills? } \\
\text { reported results are from LSD } \\
\text { paying bills and overall financial } \\
\text { include gender, age, and race. }\end{array}$ & $\begin{array}{l}\text { is } 1 \% \text { significan } \\
\text { us five years. Tl } \\
\text { rs? The credit ce } \\
\text { s your experienc } \\
\text { acial condition i } \\
\text { he scale is } 1-10 \\
\text { ument is as foll } \\
\text { ? The scale is } 1- \\
\text { V-LPM regressi } \\
\text { l condition), but } \\
\text { State-level char }\end{array}$ & $\begin{array}{l}\text { e. The data are filt } \\
\text { survey bankruptcy } \\
\text { d late payment inst } \\
\text { with credit cards? } \\
\text { trument is as follo } \\
\text { ith } 1 \text { being not at a } \\
\text { vs: In a typical mo } \\
\text { with } 1 \text { being very } \\
\text { ss. We also ran pr } \\
\text { he results are not } r \\
\text { cteristics are absent }\end{array}$ & $\begin{array}{l}\text { ed to those wh } \\
\text { astrument is as } \\
\text { ment is as follo } \\
\text { some months } \\
\text { : How satisfied } \\
\text { satisfied and } 1 \text { t } \\
\text { h, how difficult } \\
\text { ficult and } 3 \text { be } \\
\text { it and logit (o } \\
\text { terially affected } \\
\text { ecause of the }\end{array}$ & $\begin{array}{l}\text { answered yes if they took } \\
\text { ollows: Have you declared } \\
\text { us: In the past } 12 \text { months } \\
\text { was charged a late fee for } \\
\text { are you with your current } \\
\text { being extremely satisfied } \\
\text { is it for you to cover your } \\
\text { ag not at all difficult. The } \\
\text { dered probit for difficulty } \\
\text { Individual characteristics } \\
\text { rrasing of the preliminary }\end{array}$ \\
\hline
\end{tabular}

\subsubsection{Analysis on a Population of Payday Borrowers}

One criticism of our analysis so far is that the population of people who file for bankruptcy may not overlap with the population of people who take out a payday loan. To address this concern, we turn to the FINRA survey and condition the analysis on the population who have taken out a payday loan. ${ }^{10}$

Our results show that there is no statistically meaningful effect of payday loan bans on bankruptcies, difficulty in paying bills, or overall financial condition. These results generally bolster our bankruptcy analyses above: there is no discernable effect on bankruptcies, both at the aggregate level as well as the disaggreated level, that is, conditioned on the population of

\footnotetext{
${ }^{10}$ FINRA asks whether the respondent has taken out a payday loan in the past five years. We filter out all of the 'perennial banning' states, e.g., New York. We then filter the sample to only those who taken out a payday loan in the past five years. We code the BAN variable (see equation 4.1) as 0 for all states for 2009 , but a 1 for AR, AZ, NH, and MT for survey years 2012 and 2015. This is our treatment variable. The outcome variables are listed in table 8 .
} 
people who have shown themselves willing to take out a payday loan. Furthermore, we do not find any statistically meaningful relationship between general financial hardship. These findings seem to contrast with the survey-data analysis of Melzer (2011), who finds that general financial hardship -including difficulty paying bills - increases with payday loan access. One potential explanation for the difference in these findings is that Melzer's sample period is from 1996-2001, a time when the industry was relatively young. Hence, it's possible that as the industry grew and changed, so too did its customers.

A more recent survey-data analysis is Zinman (2010) who finds that Oregon's 2007 payday lending ban (implemented as a 36\% APR interest rate cap) caused people to pay their bills later. Our findings in Table 8 confirm these Zinman's findings. We find that payday lending bans led to an approximate $12 \%$ increase in late bill payment. Since credit card late fees are assessed in the subsequent month, these fees function as if they were payday loans, i.e., convenient, short-term, high-cost, etc. Furthermore, our findings bodes well with Pew (2012), which presents qualitative evidence that $62 \%$ of respondents said that they would "delay paying some bills" if payday loans were to become unavailable.

\subsection{Where Do Banned Payday Borrowers Turn for Credit?}

There is a burgeoning literature that shows that one source of financing is their bank accounts, overdrafting in particular. To be sure, payday borrowers almost always have a bank account. Indeed, payday lenders require the borrower to have a bank account (so that they can automatically withdraw funds from the account when the loan is due). Stegman (2007) says that banks are marketing their overdraft services as being, in effect, payday loans. Usury laws and interest rate caps are circumvented because the bank is charging a fee rather than issuing a loan. Overdraft fees vary from bank to bank, but they are often more expensive on an APR basis than payday loans. Banks typically charge a $\$ 30$ fee for overdrafting. If a customer overdrafts by $\$ 100$ and pays it back within two weeks-the typical maturity of a payday loan-the fees effectively add up to an APR of 780\%, a doubling of the typical payday loan APR (see D. Campbell et al. (2012)). In New Hampshire specifically, New Hampshire Public Radio ran a story titled Banks Come Under Fire for Filling in the Payday Loan Gap on December 5, 2013. ${ }^{11}$ The article points

\footnotetext{
${ }^{11}$ The article is archived here: https://web.archive.org/web/20180702030446/https://www.nhpr.org/post/banksfill-payday-loan-gap\#stream/0
} 
out that banks are effectively offering payday loans, but marketing them as "deposit advances."

Some customers are aware of the high cost of these overdraft-style loans. In the article, a consumer notes that she was not aware of just how costly it was (see Bertrand and Morse (2011) on the importance of having full information regarding payday lending costs.). Some customers, on the other hand, are aware of the high cost of overdraft fees. Stegman and Faris (2003) show that consumers who took out a payday loan did so primarily because they wanted to avoid overdraft fees.

Several studies have econometrically assessed the link between payday lending bans and overdraft fees collected by banks. D. Campbell et al. (2012) show an increase in involuntary bank closures-almost certainly a sign of defaulting on overdraft credit-in Georgia after it instituted its payday lending ban. Using a different data source, Bhutta et al. (2016) confirm this result. Morgan et al. (2012) show that bounced checks, overdraft fees, and complaint against debt collectors rise in states that ban payday lending. Meanwhile, Bhutta (2014) shows that the overdrafting is specific to banks: he finds that after a payday lending ban, consumers do not seem to be charging over their limit on their credit card. Melzer and Morgan (2015) show that banks seem to be keenly aware of a weakening of competition when payday lenders are forced out of a state: banks (and credit unions) increase the price per unit of credit when payday lenders are forced to exit the market, which is consistent with banks exercising market power.

There is also an additional, nascent literature that shows that some payday borrowers turn to pawnshop loans for financing, and some even turn to petty crime, e.g., larceny or theft. Of course, these two can go hand in hand: theft of property, which, in turn, functions as collateral for the pawnshop loan. Bhutta et al. (2016) find that pawnshop usage increases in states that ban payday lending relative to states that do not (see also Avery and Samolyk (2011)). Ramirez (2017) finds that pawnbroker licenses increased 97\% after Ohio imposed an interest rate cap of 28\%. Regarding crime, Morse (2011) finds that access to payday lending in California mitigates small property crimes in times of financial distress (proxied by a natural disaster), but cf. $\mathrm{Xu}$ (2016), who finds that some crimes decrease after a tightening of payday lending restrictions.

We pursue all of these channels of alternative financing. We analyze FINRAs triennial National Financial Capability Study to study overdrafting, pawnshop usage, credit card overlimit fees, and credit card cash advances. The benefit of the FINRA survey is that it allows us to condition on the respondents who have taken out a payday loan in the past. One critique 
Table 9: Conditional OLS DID Analysis of Alternative Financing Channels

\begin{tabular}{|c|c|c|c|c|c|c|}
\hline \multirow[t]{2}{*}{ Source } & \multicolumn{4}{|c|}{$\begin{array}{c}\text { FINRA National } \\
\text { Financial Capability Study }\end{array}$} & \multicolumn{2}{|c|}{$\begin{array}{c}\text { FBI Uniform } \\
\text { Crime Reporting }\end{array}$} \\
\hline & $\begin{array}{c}\text { Bank } \\
\text { overdraft }\end{array}$ & $\begin{array}{l}\text { Credit card } \\
\text { over-limit }\end{array}$ & $\begin{array}{l}\text { Credit card } \\
\text { advance }\end{array}$ & $\begin{array}{l}\text { Pawn shop } \\
\text { usage }\end{array}$ & $\begin{array}{l}\text { Property } \\
\text { crime }\end{array}$ & Robbery \\
\hline Study period & \multicolumn{4}{|c|}{$2009,2012,2015$} & \multicolumn{2}{|c|}{$2001-2016$} \\
\hline Sample mean & 0.560 & 0.387 & 0.340 & 0.560 & 3214.402 & 97.753 \\
\hline $\begin{array}{l}\text { Payday loan } \\
\text { restriction }\end{array}$ & $\begin{array}{c}0.050 \\
(0.067)\end{array}$ & $\begin{array}{c}0.052 \\
(0.078)\end{array}$ & $\begin{array}{c}0.173 \\
(0.101)\end{array}$ & $\begin{array}{c}0.174^{* *} \\
(0.070)\end{array}$ & $\begin{array}{c}179.251 \\
(201.034)\end{array}$ & $\begin{array}{l}10.012 \\
(6.746)\end{array}$ \\
\hline State fixed effects & $\checkmark$ & $\checkmark$ & $\checkmark$ & $\checkmark$ & $\checkmark$ & $\checkmark$ \\
\hline Year fixed effects & $\checkmark$ & $\checkmark$ & $\checkmark$ & $\checkmark$ & $\checkmark$ & $\checkmark$ \\
\hline Individual characteristics & $\checkmark$ & $\checkmark$ & $\checkmark$ & $\checkmark$ & & \\
\hline State characteristics & & & & & $\checkmark$ & $\checkmark$ \\
\hline Sample size & \multicolumn{4}{|c|}{6,821} & \multicolumn{2}{|c|}{529} \\
\hline
\end{tabular}

Notes: $*$ is $10 \% ;{ }^{* *}$ is $5 \% ; * * *$ is $1 \%$ significance. The data are filtered to those who answered yes if they took out a payday loan in the previous five years. The overdraft survey instrument is as follows: Do you (or your spouse) overdraw your checking account occasionally? The credit card over limit instrument is as follows: Yes/No to "in some months, I was charged an over the limit fee for exceeding my credit line." The credit card advance instrument is as follows: Yes/No to "in some months, I used the cards for a cash advance." The pawn shop usage instrument is as follows: In the past five years, how many times have you used a pawn shop?" We collapsed this to a simple binary measure for ease of interpretation. All of the survey instruments are binary indicators that were estimated using an LPM-LSDV model. We also estimated them with a probit model and the results are essentially the same. The interpretation of these estimates is that of a marginal effect. The FBI UCR units are crimes per 100,000 residents. All standard errors are cluster-robust, being clustered at the state level. 
of our synthetic control analysis is that we are using highly-aggregated, state-level data, and therefore perhaps that is the reason that bankruptcies are unchanged; any bankruptcy effect of a payday lending ban is masked by the fact that payday borrowers and bankruptcy filers are non-overlapping populations. Furthermore, we also test whether property crime or robberies changed. We test for changes in these alternative financing channels using OLS difference-indifferences regressions.

The signs on the coefficients are all positive, but only the pawnshop variable is significant. The credit card advance measure is significant at the $10 \%$ level, but is no longer significant once we cluster the standard errors. The finding that pawnshop usage increases is robust in light of the findings of Bhutta et al. (2016), who use a different data source, and Ramirez (2017), who studies the supply side of the pawnshop market. These findings are further strengthened by Pew (2012), which presents survey evidence of payday borrowers, $57 \%$ of whom say that they would sell/pawn personal possessions in the hypothetical scenario in which payday loans were to become unavailable. The number one response was cutting bank on expenditures, a finding confirmed by Dobridge (2018).

With respect to consumer welfare, on one hand, a revealed preference argument suggests that interest rate caps, functioning as de facto bans on payday lending, decreases the economic well-being for these consumers. But on the other hand, many payday-lending borrowers say that in the absence of a payday loan they would budget their expenses better Pew (2012); and payday borrowers generally have a harder time than the rest of the population sticking to their budgets FCAC (2016). Hence, interest rate caps-functioning as a ban on the industry-could increase consumer welfare by serving as a type of budget commitment mechanism. Therefore, we believe a promising avenue of research is to test whether the budgeting commitment effect of a payday-lending ban outweighs the costlier channels of credit effect.

\section{Section 6: Conclusion, Policy, and Future Research}

Payday loans have the potential to kick off a cycle of debt, where a high APR leads to difficulties in loan repayment, which necessitates a rolling over of another high APR loan, and so on. If consumers become trapped in this debt cycle it could lead to bankruptcy, either formal (Chapter 7,13 ) or informal (loan delinquency). State legislatures have responded to the potential for this debt trap: recently states passed legislation that caps the interest rate on small loans. 
In this paper we show compelling evidence that the caps have had their intended effect. The payday lending industry is virtually non-existent in those states. Given that the interest rate caps were effective, we should see a decrease in bankruptcy rates if the 'debt trap' hypothesis is as strong as many consumer advocates say it is. Using recent payday bans as quasi-experiments, we perform synthetic control analyses and show that, on the whole, bankruptcies and delinquencies are generally unchanged. However, we believe that our results require some qualification, especially for New Hampshire. Our New Hampshire synthetic control plots (as well as the corresponding ArCo plots) show that bankruptcies increase immediately after the ban, which suggests that payday loan access was helping to stave off bankruptcy. This finding confirms Skiba and Tobacman (2011) and Morgan et al. (2012). However, over time, the bankruptcy rates fall, even as payday lenders remain out of business. This general pattern confirms the results of Gathergood et al. (2019), who find that delinquencies in the UK decrease for those who are granted a payday loan, but then increase over time relative to those who were denied a payday loan.

Our overall findings hold up under extensions of the synthetic control method; and they also hold up when we examine survey (FINRA) data that is conditioned on a sample of previous payday borrowers. We show that these consumers turn to paying their credit cards late, as well as using pawnshops, findings that corroborates previous quantitative and qualitative evidence.

With respect to overall consumer welfare, a revealed preference argument suggests that payday lending bans makes consumers worse off. However, payday lending bans could serve as a commitment mechanism that gets people to budget their money better and become more financially literate. Presumably such actions would make these consumers better off.

We believe that a fruitful avenue of future research would be exploring the link between payday lending bans and the budgeting practices and financial education of the would-be consumers: do potential payday loan borrowers become better at budgeting their money as a result of the ban? This question fits into a larger stream of literature regarding the education of consumers and short-term, high-interest credit. For instance, Bertrand and Morse (2011) run a field experiment and show that a nudge of giving consumers full information leads consumers to borrow less at ultra-high interest rates. Lusardi and Bassa Scheresberg (2013) employ a comprehensive survey to show that payday borrowers are dramatically less informed about financial education than the general population. If financial literacy exhibits steep diminishing returns, then the 
Bertrand and Morse findings make sense.

Nonetheless, the usefulness such nudge-based policies has been questioned by J. Y. Campbell (2016), who argues that information disclosures have at least several limitations, one of which is that payday lenders can circumvent the spirit of the information disclosures, e.g., giving additional, confusing information to the consumers along with the required information. Furthermore, information disclosure may not have much of an effect since payday borrowers have been shown to have partially nave quasi-hyperbolic discounting, which helps to explain why people consistently take out such ultra-high APR loans. See also DeYoung and Phillips (2009) for evidence that APR is a bad measure of payday loan price. Given the policy importance of these issues, this literature will likely be active for years to come.

\section{References}

Abadie, A., Diamond, A., \& Hainmueller, J. (2010). Synthetic control methods for comparative case studies: Estimating the effect of california's tobacco control program. Journal of the American Statistical Association, 105, 493-505.

Agarwal, S., Gross, T., \& Mazumder, B. (2016). How did the great recession affect payday loans? Economic Perspectives, Federal Reserve Bank of Chicago(2), 1-12.

Avery, R. B., \& Samolyk, K. A. (2011). Payday loans versus pawn shops: The effects of loan fee limits on household use. (Working Paper)

Barth, J. R., Hilliard, J., Jahera, J. S., \& Sun, Y. (2016). Do state regulations affect payday lender concentration? Journal of Economics and Business, 84, 14-29.

Bertrand, M., \& Morse, A. (2011). Information disclosure, cognitive biases, and payday borrowing. Journal of Finance, 66, 1865-1893.

Bhutta, N. (2014). Payday loans and consumer financial health. Journal of Banking and Finance, 47, 230-242.

Bhutta, N., Goldin, J., \& Homonoff, T. (2016). Consumer borrowing after payday loan bans. Journal of Law and Economics, 59, 225-259.

Bhutta, N., Skiba, P. M., \& Tobacman, J. (2015). Payday loan choices and consequences. Journal of Money, Credit and Banking, 47, 223-259.

Bohn, S., Lofstrom, M., \& Raphael, S. (2014). Did the 2007 legal arizona workers act reduce the state's unauthorized immigrant population? The Review of Economics and Statistics, 96, 258-269.

Buckland, J., Robinson, C., \& Visano, B. S. (Eds.). (2018). Payday lending in canada in a global context: A mature industry with chronic challenges. Palgrave-Macmillan.

Campbell, D., Martinez-Jerez, F. A., \& Tufano, P. (2012). Bouncing out of the banking system: An empirical analysis of involuntary bank account closures. Journal of Banking and Finance, 36, 1224-1235.

Campbell, J. Y. (2016). Restoring rational choice: The challenge of consumer financial regulation. (ECB Working Paper No 1897) 
Carrell, S., \& Zinman, J. (2014). In harm's way? payday loan access and military personnel performance. Review of Financial Studies, 27, 2806-2840.

Carter, S. P., \& Skimmyhorn, W. (2017). Much ado about nothing? new evidence on the effects of payday lending on military members. The Review of Economics and Statistics, 99, 606-621.

Carvalho, C., Masini, R., \& Medeiros, M. C. (2018). Arco: An artificial counterfactual approach for high-dimensional panel time-series data. Journal of Econometrics, 207, 352-380.

CFPB. (2014, March). Cfpb data point: payday lending (Tech. Rep.). Consumer Financial Protection Bureau.

Cuffe, H. E., \& Gibbs, C. G. (2017). The effect of payday lending restrictions on liquor sales. Journal of Banking and Finance, 85, 132-145.

Desai, C. A., \& Elliehausen, G. (2017). The effect of state bans of payday lending on consumer credit delinquencies. The Quarterly Review of Economics and Finance, 64, 94-107.

DeYoung, R., \& Phillips, R. J. (2009, February). Payday loan pricing. (Federal Reserve Bank of Kansas City Working Paper)

Dobbie, W., \& Skiba, P. M. (2013). Information asymmetries in consumer credit markets: evidence from payday lending. American Economic Journal: Applied Economics, 5, 256282.

Dobridge, C. L. (2018). High-cost credit and consumption smoothing. Journal of Money, Credit and Banking, 50, 407-433.

Doudchenko, N., \& Imbens, G. W. (2016). Balancing, regression, difference-in-differences and synthetic control methods: A synthesis. (NBER Working Paper 22791)

Edmiston, K. D. (2011). Could restrictions on payday lending hurt consumers? Economic Review, Federal Reserve Bank of Kansas City (issue Q1).

FCAC. (2016, October). Payday loans: market trends (Tech. Rep.). Financial Consumer Agency of Canada.

Flannery, M., \& Samolyk, K. (2005). Payday lending: Do the costs justify the price? (FDIC Working Paper)

Fonseca, Y. R., Masini, R. P., Medeiros, M. C., \& Vasconcelos, G. F. (2018). Arco: An r package to estimate artificial counterfactuals. The $R$ Journal, 10, 91-108.

Galiani, S., \& Quistorff, B. (2017). The synth runner package: Utilities to automate synthetic control estimation using synth. Stata Journal, 17(4), 834-849.

Gathergood, J., Guttman-Kenney, B., \& Hunt, S. (2019). How do payday loans affect borrowers? evidence from the uk market. Review of Financial Studies, 32, 496-523.

Hynes, R. (2012). Payday lending, bankruptcy, and insolvency. Washington and Lee Law Review, 69, 607-648.

Karlan, D., \& Zinman, J. (2010). Expanding credit access: Using randomized supply decisions to estimate the impacts. The Review of Financial Studies, 23, 433-464.

Lee, J. (2017). Credit access and household well-being: Evidence from payday lending. (Working Paper)

Lefgren, L., \& McIntyre, F. (2009). Explaining the puzzle of cross-state differences in bankruptcy rates. Journal of Law and Economics, 52, 367-393.

Levin, A., Lin, C.-F., \& Chu, C.-S. J. (2002). Unit root tests in panel data: Asymptotic and finite-sample properties. Journal of Econometrics, 108, 1-24.

Li, M., Mumford, K. J., \& Tobias, J. L. (2012). A bayesian analysis of payday loans and their regulation. Journal of Econometrics, 171, 205-216. 
Livshits, I., MacGee, J., \& Tertilt, M. (2010). Accounting for the rise in consumer bankrutpcies. American Economic Journal: Macroeconomics, 2, 165-193.

Lusardi, A., \& Bassa Scheresberg, C. de. (2013). Financial literacy and high-cost borrowing in the united states. (NBER Working Paper 18969)

Melzer, B. T. (2011). The real costs of credit access: Evidence from the payday lending market. Quarterly Journal of Economics, 126, 517-555.

Melzer, B. T. (2013). Payday loans increase snap, reduce child support payments. UC David Center for Poverty Research Policy Brief, 2(6).

Melzer, B. T., \& Morgan, D. P. (2015). Competition in a consumer loan market: Payday loans and overdraft credit. Journal of Financial Intermediation, 24, 25-44.

Morgan, D. P., Strain, M. A., \& Seblani, I. (2012). How payday credit access affects overdrafts and other outcomes. Journal of Money, Credit and Banking, 44, 519-531.

Morse, A. (2011). Payday lenders: Heroes or villains? Journal of Financial Economics, 102, $28-44$.

Pew. (2012, July). Payday lending in america: Who borrows, where they borrow, and why (Tech. Rep.). Pew Charitable Trusts.

Ramirez, S. R. (2017). Payday-loan bans: Evidence of indirect effects on supply. (Working Paper)

Rigbi, O. (2013). The effects of usury laws: evidence from the online loan market. The Review of Economics and Statistics, 95, 1238-1248.

Skiba, P. M., \& Tobacman, J. (2011). Do payday loans cause bankruptcy? (Working paper)

Stegman, M. A. (2007). Payday lending. Journal of Economic Perspectives, 21, 169-190.

Stegman, M. A., \& Faris, R. (2003). Payday lending: A business model that encourages chronic borrowing. Economic Development Quarterly, 17, 8-32.

Stoianovici, P. S., \& Maloney, M. T. (2010). Restrictions on credit: A public policy analysis of payday lending. (Working Paper)

$\mathrm{Xu}, \mathrm{Y}$. (2016). Payday loan regulation and neighborhood crime. (Working Paper)

Zaki, M. (2016). Access to short-term credit and consumption smoothing within the paycycle. (Working Paper)

Zinman, J. (2010). Restricting consumer credit access: Household survey evidence on effects around the oregon rate cap. Journal of Banking and Finance, 34, 546-556. 


\section{Appendix}

Table A.1: History of payday lending regulations by state

\begin{tabular}{|c|c|c|c|c|}
\hline States & $\begin{array}{l}\text { Permissive or } \\
\text { restrictive? }\end{array}$ & Related statute & Effective dates & S Supplementary information and anecdotes \\
\hline Alabama & Permissive & $\begin{array}{l}\text { Code of Ala. } \S 5- \\
18 \text { A-1 }\end{array}$ & $\begin{array}{l}\text { Effective in June } \\
2003\end{array}$ & $\begin{array}{l}\text { - The state's payday lending law is known as the Deferred Presentment Services Act (2003). The law introduces } \\
\text { minimal regulations in terms of payday lending business and licensing requirements. } \\
\text { - The interest rate cap applied by the state's 'Small Loan Act' does not apply to the payday lending business. The } \\
\text { annual percentage rate on payday loans can vary up to } 456 \% \text {. } \\
\text { - There was presence of payday lending businesses prior to the } 2003 \text { legislation (during the 1990's). }\end{array}$ \\
\hline Alaska & Permissive & $\begin{array}{l}\text { Alaska Stat. } \S \S \\
06.50 .010 \text { et seq. }\end{array}$ & $\begin{array}{l}\text { Effective in January } \\
2005 \text { (the act was } \\
\text { approved in June } \\
\text { 2004) }\end{array}$ & $\begin{array}{l}\text { - The state's payday lending authorization law is also known as the 'Deferred Deposit Advances' act. The act } \\
\text { regulates payday lending business (including license requirements). } \\
\text { - Annual percentage rate of interest can vary up to } 520 \% \text {. } \\
\text { - Before 2005, payday lending was illegal under the interest cap imposed by the state's usury law (or small loan) } \\
\text { law. }\end{array}$ \\
\hline Arizona & Restrictive & $\begin{array}{l}\text { Ariz. Rev. Stat. } \\
\text { Ann. } \S \S 6-601 \text { et } \\
\text { seq./ } § 6-1263\end{array}$ & $\begin{array}{l}\text { Approved and } \\
\text { effective in April } \\
2000 \text { and was } \\
\text { allowed to expire in } \\
\text { July } 2010\end{array}$ & $\begin{array}{l}\text { - In } 2000 \text {, the state passed a law, which exempted payday lenders from the existing } 36 \% \text { annual percentage rate } \\
\text { cap for small loan products. The loans could effectively reach a maximum annual percentage rate of } 1288 \% \text {. } \\
\text { - In July } 2010 \text {, the statute was allowed to expire and payday lending became illegal. Currently, consumer loans } \\
\text { with annual interest rates above } 36 \% \text { are illegal in the state. }\end{array}$ \\
\hline Arkansas & Restrictive & $\begin{array}{l}\text { Ark. Code Ann. 23- } \\
52-101 \text { et. Seq }\end{array}$ & $\begin{array}{l}\text { Approved and } \\
\text { effective in April } \\
\text { 1999; repealed in } \\
\text { March } 2011\end{array}$ & $\begin{array}{l}\text { - Before the act of } 1999 \text {, payday lending was restricted by the state's usury law that put an annual interest cap of } \\
17 \% \text { on consumer loans. } \\
\text { - A large number of payday lenders lobbied for a law to legalize their business. The Check-Cashers Act (1999) } \\
\text { was passed to legalize and regulate payday lending activities in the state. } \\
\text { - The average annual percentage rate on payday loans in } 2007 \text { was found to be approximately } 432 \% \text {. } \\
\text { - In 2008, the state's Attorney General filed lawsuits against several payday lending firms and eventually, the } \\
\text { state's supreme court suggested that allowing lenders to charge high interest rates (in form of 'service fees') } \\
\text { violated the constitutional provisions. } \\
\text { - The Check-Cashers Act was ultimately repealed in } 2011 \text {. }\end{array}$ \\
\hline California & Permissive & $\begin{array}{l}\text { Cal. Fin. Code } \\
\S \S 23000 \text { to } 23106\end{array}$ & $\begin{array}{l}\text { Authorized payday } \\
\text { lending in February } \\
1996 ; \text { amended in } \\
\text { assembly in June } \\
1996\end{array}$ & $\begin{array}{l}\text { - The state legislature legalized payday loans in } 1996 \text {. } \\
\text { - In } 2002 \text { (but effective from December } 31,2004 \text { ), the California Deferred Deposit Transaction Law was } \\
\text { approved. This law shifted the payday lending oversight from the state's Department of Justice to the } \\
\text { Department of Corporations and to impose licensing requirements for the payday lenders. } \\
\text { - The annual percentage rate on a 14-day } \$ 100.00 \text { loan can be as high as } 459 \% \text {. }\end{array}$ \\
\hline
\end{tabular}




\begin{tabular}{|c|c|c|c|c|}
\hline States & $\begin{array}{l}\text { Permissive or } \\
\text { restrictive? }\end{array}$ & Related statute & Effective dates & "Supplementary information and anecdotes \\
\hline Colorado & $\begin{array}{l}\text { Restrictive } \\
\text { under } \\
\text { conditions }\end{array}$ & $\begin{array}{l}\text { Colo. Rev. Stat. 5- } \\
3.1-101 \text { et seq. }\end{array}$ & $\begin{array}{l}\text { Effective in July } \\
\text { 2000; Amendment } \\
\text { H.B. } 1351 \\
\text { signed by governor } \\
\text { in May } 2010\end{array}$ & $\begin{array}{l}\text { - In 2000, the state legalized payday lending by enacting the Deferred Deposit Loan Act. } \\
\text { - A } 2010 \text { state law imposed restrictions on payday lending. The restrictions limited the amount that could be } \\
\text { borrowed, prohibited renewal of law for more than once, and allowed borrowers to have six months to repay. } \\
\text { - A payday loan may include an interest rate of } 45 \% \text { per annum plus maintenance fees (of } 7.5 \% \text { after the first } \\
\text { month) and a tiered system of finance charges depending on the amount borrowed. }\end{array}$ \\
\hline Connecticut & Restrictive & $\begin{array}{l}\text { Conn. Gen. Stat. } \\
36 a-563\end{array}$ & $\begin{array}{l}\text { Restricted since } \\
1949 \text { (1949 Rev., S. } \\
6779 .)\end{array}$ & $\begin{array}{l}\text { - In } 1949 \text {, the state's banking legislation (Chapter } 37-4) \text { prohibited usury charges above } 12 \% \text {. } \\
\text { - In } 1981 \text {, personal loans above } \$ 5000 \text { and business loans above } \$ 10,000 \text { were exempted from the } 12 \% \text {-cap. } \\
\text { - The statute } 36 a-563 \text { regulates small loan businesses. }\end{array}$ \\
\hline Delaware & Permissive & $\begin{array}{l}\text { Del. Code Ann. Tit. } \\
52227 \text { et seq. }\end{array}$ & $\begin{array}{l}\text { Approved in May } \\
1987\end{array}$ & $\begin{array}{l}\text { - The state's office of the State Bank Commissioner regulates payday lending business since } 1987 . \\
\text { - The House Bill } 289 \text { of } 2012 \text { (approved on June } 27,2012 \text { ) limited the number of payday loans a consumer } \\
\text { could borrow to five (over a duration of a year). The definition of short-term loans was updated to include loans } \\
\text { up to an amount of } \$ 1000 \text { (as against } \$ 500 \text { ). } \\
\text { - There is no limit to the annual percentage rate/finance fees that could be charged on a 14-day } \$ 100 \text { loan. }\end{array}$ \\
\hline $\begin{array}{l}\text { District of } \\
\text { Columbia }\end{array}$ & Restrictive & $\begin{array}{l}\text { D.C. Code Ann. 28- } \\
\text { 3301(a); 26-319 }\end{array}$ & $\begin{array}{l}\text { Legalized payday } \\
\text { lending in April } \\
\text { 1998; Unauthorized } \\
\text { payday lending in } \\
\text { October 2007; } \\
\text { Capped small loan } \\
\text { interest rate to 24\% } \\
\text { in May } 2008\end{array}$ & $\begin{array}{l}\text { - The state enacted a bill to in the } 1998 \text { session to permit and regulate payday lending business. } \\
\text { - The 'Payday Loan Consumer Protection Amendment Act of } 2007 \text { ' prohibited payday lending activities. } \\
\text { - In 2008, the state's city council passed a bill that imposed a } 24 \% \text { interest cap on small loans. }\end{array}$ \\
\hline Florida & Permissive & $\begin{array}{l}\text { Fl. Stat. Ann. } \\
\S \S 560.402 \text { et seq. }\end{array}$ & $\begin{array}{l}\text { Effective in May } \\
2001\end{array}$ & $\begin{array}{l}\text { - Payday lending businesses existed in the state since before } 2001 \text { in the absence of state restrictions. } \\
\text { - The } 2001 \text { law (a.k.a the 'Deferred Presentment Act') was enacted to regulate payday lending businesses as a } \\
\text { measure to protect consumers from rising debt obligations. } \\
\text { - Under the existing law, a payday loan may not exceed an amount of } \$ 500 \text {. The loan term should range from } 7 \\
\text { to } 31 \text { days. } \\
\text { - Usually, the annual percentage rate on payday loans amounts to } 419 \% \text {, but can be in excess of } 500 \% \text { as well. }\end{array}$ \\
\hline
\end{tabular}




\begin{tabular}{|c|c|c|c|c|}
\hline States & $\begin{array}{l}\text { Permissive or } \\
\text { restrictive? }\end{array}$ & Related statute & Effective dates & "Supplementary information and anecdotes \\
\hline Georgia & Restrictive & $\begin{array}{l}\text { Ga. Code Ann. } \S \S \\
16-17-1 \text { et seq. }\end{array}$ & $\begin{array}{l}\text { Restriction } \\
\text { approved in April } \\
2004 \text { and effective } \\
\text { from May } 2004 \\
\text { under racketeering } \\
\text { law }\end{array}$ & $\begin{array}{l}\text { - The state prohibits payday loans under racketeering laws and recognizes payday lending activities as a } \\
\text { felonious crime. } \\
\text { - Under the current provisions of the 'Industrial Loan Act' (which was originally passed in 1955), the annual } \\
\text { percentage rate on small loans is capped at } 60 \% \text {. }\end{array}$ \\
\hline Hawaii & Permissive & $480 \mathrm{~F}-1$ et seq & $\begin{array}{l}\text { Approved in June } \\
1999 ; \text { and effective } \\
\text { from July } 1999\end{array}$ & $\begin{array}{l}\text { - Payday was legalized in the state in } 1999 . \\
\text { - The } 1999 \text { legislation was supposed to expire in } 2001 \text {; however, the provision was removed in } 2001 \text {. } \\
\text { - The annual percentage rate can range up to } 459 \% \text { on } 14 \text {-day } \$ 100 \text { loan and the maximum loan amount is } \$ 600 \text {. }\end{array}$ \\
\hline Idaho & Permissive & $\begin{array}{l}\text { Idaho Code } \S \S 28 \text { - } \\
46-401 \text { et seq. }\end{array}$ & $\begin{array}{l}\text { Approved in March } \\
\text { 2003; effective } \\
\text { from July } 2003\end{array}$ & $\begin{array}{l}\text { - Prior to the } 2003 \text { law, payday lenders could operate in the state as regulated lender licensees under the Idaho } \\
\text { Credit Code. } \\
\text { - There is no limit to the annual percentage rate that could be charged on a small loan. The average annual } \\
\text { percentage rate on payday loans in the state is found to be approximately } 521 \% \text {. }\end{array}$ \\
\hline Illinois & Permissive & $\begin{array}{l}815 \text { ILCS } 122 \text { et } \\
\text { seq. }\end{array}$ & $\begin{array}{l}\text { Effective in } \\
\text { December } 2005\end{array}$ & $\begin{array}{l}\text { - Payday lending business was unregulated until the 'Payday Loan Reform Act' was enacted in } 2005 \text {. Prior to } \\
\text { the act, there were limited state restrictions on payday lending activities. As a result, the average annual } \\
\text { percentage rate on payday loans was as high as } 595 \% \text {. } \\
\text { - The } 2005 \text { act introduced several restrictions with respect to the number of loans that can be borrowed at one } \\
\text { time; finance charges (not to exceed } \$ 15.50 \text { per } \$ 100) \text {; total loan amount; and duration of a loan. } \\
\text { - Public Acts } 97-0421 \text { and } 97-0413 \text { of } 2011 \text { introduce further restrictions in terms of violation of the existing } \\
\text { Payday Loan Reform Act and finance charges conditional on the duration of the first instalment periods. } \\
\text { - Currently, the annual percentage rate on a } 14 \text {-day } \$ 100 \text { loan is } 403 \% \text { with loan term in the range of } 13-45 \\
\text { days. The maximum amount that can be borrowed is } \$ 1000 \text { or } 25 \% \text { of gross monthly income, whichever is } \\
\text { lower. }\end{array}$ \\
\hline Indiana & Permissive & $\begin{array}{l}\text { Ind. Code } \S \S 24-4- \\
4.5-7-101 \text { et seq. }\end{array}$ & $\begin{array}{l}\text { Effective in March } \\
2002\end{array}$ & $\begin{array}{l}\text {-Payday lending existed in the state before the Small Loans Act was enacted in } 2002 \text { to regulate the payday } \\
\text { lending business. The act imposes a cap on the number of payday loans that can be borrowed and interest } \\
\text { charged on those loans. } \\
\text { - The maximum small loan amount and allowable finance charges were increased in a } 2004 \text { amendment of the } \\
\text { act. } \\
\text { - The annual percentage rate on a } 14 \text {-day } \$ 100 \text { loan is } 390 \% \text { along with a finance charge of } 15.5 \% \text {. }\end{array}$ \\
\hline
\end{tabular}




\begin{tabular}{|c|c|c|c|c|}
\hline States & $\begin{array}{l}\text { Permissive or } \\
\text { restrictive? }\end{array}$ & Related statute & Effective dates & Supplementary information and anecdotes \\
\hline Iowa & Permissive & $\begin{array}{l}\text { Iowa Code Ann. } \\
\text { 533D. } 1 \text { et seq. }\end{array}$ & $\begin{array}{l}\text { Effective in May } \\
1995\end{array}$ & $\begin{array}{l}\text { - The } 1995 \text { legislation allowed lenders licensed under the Special Usury Statutes to charge interest rates on } \\
\text { small loans in excess of the rates permissible under the existing acts (such as the Consumer Loan Act or the } \\
\text { Industrial Loan Act) that cap interest rates on small loans below } 36 \% \text {. } \\
\text { - The annual percentage rate of } 14 \text {-day } \$ 100 \text { loan is } 433 \% \text { with finance charges of } \$ 16.67 \text {. }\end{array}$ \\
\hline Kansas & Permissive & $\begin{array}{l}\text { Kan. Stat. } \\
\text { Ann. § 16a-2-404, } \\
405\end{array}$ & $\begin{array}{l}\text { Effective in March } \\
1993\end{array}$ & $\begin{array}{l}\text { - Payday lending business in the state has been regulated by The Office of the State Bank Commissioner since } \\
1993 \text {. } \\
\text { - The maximum loan amount is } \$ 500 \text {. The annual percentage rate on a } 14 \text {-day } \$ 100 \text { loan is } 390 \% \text { along with a } \\
\text { finance charge of } 15 \% \text {. }\end{array}$ \\
\hline Kentucky & Permissive & $\begin{array}{l}\text { Kentucky Rev. Stat. } \\
\text { Ann. } \S \S 286.9 .010 \\
\text { et seq. }\end{array}$ & $\begin{array}{l}\text { Effective in April } \\
1998\end{array}$ & $\begin{array}{l}\text { - The } 1998 \text { legislation authorizes payday lending business to charge interest rate as high as } 400 \% \text { on small } \\
\text { loans. } \\
\text { - In 2010, the state implemented a legislation which attempts to restrict payday loan use, but still allowed } \\
\text { payday lending firms to charge high interest rates (2009 Ky. House Bill } 444 \text { enacted in March, } 2009 \text { but to take } \\
\text { effect from January, 2010). } \\
\text { - The annual percentage rate on a 14-day } \$ 100 \text { loan is } 459 \% \text { with finance charges of } \$ 17.65 \text {. }\end{array}$ \\
\hline Louisiana & Permissive & $\begin{array}{l}\text { La. Rev. Stat. } \\
\text { Ann. §§ 9:3578.1 et } \\
\text { seq. }\end{array}$ & $\begin{array}{l}\text { Effective in January } \\
2000 \text { (approved by } \\
\text { governor on July } \\
1999 \text { ) }\end{array}$ & $\begin{array}{l}\text { - The } 2000 \text { legislation can be cited as the 'Deferred Presentment and Small Loan Act'. The act provides } \\
\text { guidelines and regulations regarding payday lending business. } \\
\text { - The annual percentage rate on a } 14 \text {-day } \$ 100 \text { loan can be as high as } 780 \% \text { with finance charge of } \$ 30 \text {. The } \\
\text { maximum loan amount if } \$ 350 \text {. }\end{array}$ \\
\hline
\end{tabular}




\begin{tabular}{|c|c|c|c|c|}
\hline$\overline{\text { States }}$ & $\begin{array}{l}\text { Permissive or } \\
\text { restrictive? }\end{array}$ & Related statute & Effective dates & Supplementary information and anecdotes \\
\hline Maryland & Restrictive & $\begin{array}{l}\text { Md. Code Com. } \\
\text { Law § 12-101 et } \\
\text { seq. }\end{array}$ & $\begin{array}{l}\text { The current } \\
\text { structure of the } \\
\text { maximum } \\
\text { chargeable interest } \\
\text { rate on small loans } \\
\text { was introduced in } \\
\text { state legislation } \\
\text { dated May } 1980\end{array}$ & $\begin{array}{l}\text { - The state never authorized payday lending. Payday lending is restricted by the state's Consumer Loan Act. } \\
\text { - Further, the state's usury law (Article } 49 \text { of Maryland Annotated Code of 1957) prohibits lenders to charge high } \\
\text { interest rates on loans (capped at interest } 6 \% \text { annual interest rate). } \\
\text { - Since the } 1977 \text { legislation, Maryland amended their existing legislation to move from a flat annual interest rate } \\
\text { to variable interest rates. } \\
\text { - The small loan (for an amount of } \$ 500 \text { or less) annual interest rate is capped at } 33 \% \text {. } \\
\text { - In 2001, Maryland tightened their measure against payday lending business further by banning in-state credit } \\
\text { services to collaborate with out-of-state lenders and charge interest rates higher than the permissible limit. }\end{array}$ \\
\hline Massachusetts & Restrictive & $\begin{array}{l}\text { Mass. Gen. Laws } \\
\text { Ann. ch. } 140 \S \S 96 \\
\text { et seq.; } 209 \text { Mass. } \\
\text { Code Regs. } 26.01 \text {. }\end{array}$ & $\begin{array}{l}\text { The small loan act } \\
\text { (that limits that } \\
\text { maximum } \\
\text { chargeable interest } \\
\text { rate) was enacted in } \\
\text { January } 1898\end{array}$ & $\begin{array}{l}\text { - Payday lending was never authorized in the state. Check cashers are prohibited from advancing loans unless } \\
\text { licensed under the small loan act (209 Mass. Code Regs. } 45: 14(8) \text { ). } \\
\text { - The maximum chargeable annual interest rate on loans up to } \$ 6000 \text { is } 23 \% \text { plus an administrative fee of } \$ 20 \\
\text { once a loan has been granted. }\end{array}$ \\
\hline Michigan & Permissive & $\begin{array}{l}\text { Mich. Comp. Laws } \\
\S \S 487.2121 \text { et seq. }\end{array}$ & $\begin{array}{l}\text { Effective in } \\
\text { November } 2005\end{array}$ & $\begin{array}{l}\text { - The 'Deferred Presentment Service Transactions Act' ( } 2005 \text { ) permitted payday lending businesses to operate } \\
\text { in the state in exchange for regulation by the Department of Insurance and Financial Institutions (DIFS). } \\
\text { - The } 2005 \text { act provided several terms and conditions to protect consumers from practices that can lead to high } \\
\text { risks of financial abuse including licensing requirements by the DIFS; limits on fees and interest rates; ban on } \\
\text { rollovers; maximum loan advance from a single lender ( } \$ 600) ; \text { loan term ( } 7 \text { to } 31 \text { days). } \\
\text { - All the existing deferred presentment providers (payday lending firms) are required to be licensed by January } \\
2006 \text {. } \\
\text { - The maximum limit on service fees on a two-week loan are as follows: } 15 \% \text { on } 1 \text { st } \$ 100 ; 14 \% \text { on } 2 \text { nd } \$ 100 \text {; } \\
13 \% \text { on 3rd } \$ 100 ; 12 \% \text { on } 4 \text { th } \$ 100 ; \text { and } 11 \% \text { on } 5 \text { th and } 6 \text { th } \$ 100 \text {. The annual percentage rate on a } 2 \text {-week } \\
\$ 100 \text { loan is approximately } 391 \% \text {. } \\
\text {-Payday lending businesses existed in the state prior to the } 2005 \text { legislation. }\end{array}$ \\
\hline Minnesota & Permissive & $\begin{array}{l}\text { Minn. Stat. } 47.60 \text { et } \\
\text { seq. (The consumer } \\
\text { small loan act) }\end{array}$ & $\begin{array}{l}\text { Effective in } \\
\text { September } 1995 \\
\text { (approved in May } \\
\text { 1995) }\end{array}$ & $\begin{array}{l}\text {-Payday lending business was illegal until } 1995 \text {. The state's Department of Commerce has been regulating } \\
\text { Payday Loans and Cash Advances since the small loan act was enacted } 1995 \text {. } \\
\text {-The annual percentage rate on 14-day } \$ 100 \text { loan is } 390 \% \text {. The maximum loan amount that can be drawn from a } \\
\text { single lender is } \$ 350 \text {. }\end{array}$ \\
\hline
\end{tabular}




\begin{tabular}{|c|c|c|c|c|}
\hline States & $\begin{array}{l}\text { Permissive or } \\
\text { restrictive? }\end{array}$ & Related statute & Effective dates & Supplementary information and anecdotes \\
\hline Mississippi & Permissive & $\begin{array}{l}\text { Miss. Code Ann. } \S \S \\
75-67-501 \text { et seq. }\end{array}$ & $\begin{array}{l}\text { Effective in June } \\
1998 \text { (approved in } \\
\text { April 1998) }\end{array}$ & $\begin{array}{l}\text { - Prior to 1998, the state lenders were not permitted to offer small loans with more than a } 36 \text { percent annual } \\
\text { percentage rate. The } 1998 \text { legislation also known as the Mississippi Check Cashers Act legalized payday lending } \\
\text { activities in the state. } \\
\text { - The maximum finance rate (and services fees) is } 20 \% \text { for an amount under } 250 \text { and } 21.95 \% \text { for an amount } \$ 250 \text { - } \\
500 \text {. The annual percentage rate on a } 14 \text {-day } \$ 100 \text { loan can be as high as } 520 \% \text {. }\end{array}$ \\
\hline Missouri & Permissive & $\begin{array}{l}\text { Mo. Rev. Stat. } \S \S \\
408.500 .1 \text { et seq. }\end{array}$ & $\begin{array}{l}\text { Effective in January } \\
1991 \text { (approved in } \\
\text { July 1990) }\end{array}$ & $\begin{array}{l}\text { - The } 1991 \text { legislation changed the state's existing usury laws to allow the business of advancing high-interest } \\
\text { short term loans. } \\
\text { - In 2006, the payday lending law was amended to restrict the maximum loan amount to } \$ 500 \text {. } \\
\text { - In } 2011 \text {, the state passed a bill payday to cap annual interest rates on payday loans at } 1,564 \% \text { (House Bill } 656 \text { ). } \\
\text { - The loan term on a payday loan ranges between } 14 \text { and } 31 \text { days. }\end{array}$ \\
\hline Montana & Restrictive & $\begin{array}{l}\text { Mont. Code Ann. } \\
31-1-701\end{array}$ & $\begin{array}{l}\text { Effective in January } \\
2011 \text { (approved in } \\
\text { November 2010) }\end{array}$ & $\begin{array}{l}\text { - A ballot initiative passed by the state's voters capped annual interest rates on loans at } 36 \% \text { in } 2010 \text { (effective } \\
\text { from the beginning of 2011). } \\
\text { - Approximately half of all payday loans went to borrowers with } 13 \text { or more loans per year right before the } \\
\text { interest rate cap was passed in } 2010 \text {. } \\
\text { - Payday lending was legal and regulated under the Montana Deferred Deposit Loan Act (effective in April } \\
\text { 1999). }\end{array}$ \\
\hline Nebraska & Permissive & $\begin{array}{l}\text { Neb. Stat. Ann. } \S \S \\
45-901\end{array}$ & $\begin{array}{l}\text { Effective in } \\
\text { October } 1994 \\
\text { (approved in April } \\
\text { 1994) }\end{array}$ & $\begin{array}{l}\text { - The payday lending business is regulated and licensed under the } 1994 \text { legislation, which is also known as the } \\
\text { Delayed Deposit Services Licensing Act. } \\
\text {-The maximum loan amount is } \$ 500 \text { with an annual percentage rate on a 14-day } \$ 100 \text { loan of } 459 \% \text {. }\end{array}$ \\
\hline Nevada & Permissive & $\begin{array}{l}\text { Nev. Rev. Stat. } \\
\text { 604A.010 et seq. }\end{array}$ & $\begin{array}{l}\text { Effective in July } \\
2005 \text { (approved in } \\
\text { June 2005) }\end{array}$ & $\begin{array}{l}\text { - High-interest payday lending business existed in the state for several decades before the } 2005 \text { legislation was } \\
\text { enacted to regulate payday lending activities. } \\
\text {-The } 2005 \text { legislation prohibited payday lending firms to use criminal actions against their borrowers. } \\
\text {-The maximum loan amount should not exceed } 25 \% \text { of gross monthly salary with no limit on annual percentage } \\
\text { rate on payday loan. }\end{array}$ \\
\hline New Hampshire & Restrictive & $\begin{array}{l}\text { N.H. Rev. Stat. } \\
\text { Ann. 399-A:1 et } \\
\text { seq. }\end{array}$ & $\begin{array}{l}\text { Effective in January } \\
2009\end{array}$ & $\begin{array}{l}\text { - Payday lending was prohibited in the state prior to } 1999 \text { (the year when the business was legalized). } \\
\text {-The } 2008 \text { legislation (effective from the January 2009) the state implemented a law restricting the annual } \\
\text { interest rate on payday loans to } 36 \% \text {. }\end{array}$ \\
\hline
\end{tabular}




\begin{tabular}{|c|c|c|c|c|}
\hline States & $\begin{array}{l}\text { Permissive or } \\
\text { restrictive? }\end{array}$ & Related statute & Effective dates & S Supplementary information and anecdotes \\
\hline New Jersey & Restrictive & $\begin{array}{l}\text { N.J. Stat. Ann. 2C: } \\
\text { 21-19, 17:11C- } \\
\text { 36(a); N.J. Stat. } \\
\text { Ann. tit. 17:1 et } \\
\text { seq; N.J. Stat. Ann. } \\
\text { 17:15A-47 }\end{array}$ & $\begin{array}{l}\text { N.J. Stat. Ann. 2C: } \\
\text { 21-19, 17:11C- } \\
\text { 36(a): Effective in } \\
\text { March 1981 } \\
\text { N.J. Stat. Ann. tit. } \\
\text { 17:1: Effective in } \\
\text { July 1948 } \\
\text { N.J. Stat. Ann. } \\
\text { 17:15A-47: } \\
\text { Approved in } \\
\text { January 1994 and } \\
\text { was proposed to be } \\
\text { effective in April } \\
\text { 1994 }\end{array}$ & $\begin{array}{l}\text { - Payday lending is restricted by the state under the legal provisions of the Consumer Loan Act (N.J. Stat. Ann. } \\
\text { tit. 17:1 et seq). } \\
\text { - The annual interest rate on loans is capped at } 30 \% \text { (usury cap) (N.J. Stat. Ann. 2C: } 21-19,17: 11 \text { C-36(a)). } \\
\text { - A check cashing licensee cannot advance money on a post-dated check (N.J. Stat. Ann. 17:15A-47) }\end{array}$ \\
\hline New Mexico & Permissive & $\begin{array}{l}\text { N.M. Stat. Ann. } \\
\text { Sec.58-15-1 et seq. }\end{array}$ & $\begin{array}{l}\text { Effective in March } \\
1955\end{array}$ & $\begin{array}{l}\text { - Payday lending business is regulated by the state's Small Loan Act of } 1955 \text {. The act does not explicitly put any } \\
\text { restrictions on the interest rates that can be charged on small loans; however, under special circumstances (such } \\
\text { as death of the borrower, loan approved as a claim in bankruptcy proceedings, or during the period of one year } \\
\text { after the maturity of the loan term) the interest rate may not exceed } 10 \% \text {. } \\
\text { - The annual percentage rate on } 14 \text {-day } \$ 100 \text { loan is approximately } 417 \% \text { and the maximum loan amount that can } \\
\text { be borrowed is } \$ 2,500 \text {. } \\
\text { - In April } 2017 \text {, a bill was enacted to remove payday lending activities from the provisions of the small loan act } \\
\text { of } 1955 \text {. Among other provisions, the new law caps the annual interest rate on small loans at } 175 \% \text { and extends } \\
\text { the loan term to a minimum of } 4 \text { months. }\end{array}$ \\
\hline New York & Restrictive & $\begin{array}{l}\text { NY CLS Penal } \S \\
190.40 ; \text { NY } \\
\text { Banking Law } 373 \\
\text { NY Banking Law } \\
340 \text { et seq }\end{array}$ & $\begin{array}{l}\text { NY CLS Penal } \\
\text { 190.40: Effective in } \\
\text { June } 1976 \\
\text { NY Banking Law } \\
\text { 373: Effective in } \\
\text { April } 1944 \\
\text { NY Banking Law } \\
340 \text { et seq: } \\
\text { Effective in June } \\
1974\end{array}$ & $\begin{array}{l}\text { - The terms on the interest rates on a loan should be governed by the contract that a borrower and lender enter } \\
\text { into (N.Y. Banking Law } 340 \text { et seq.). } \\
\text { - A check casher cannot advance loans on a post-dated check unless it is a payroll check (NY Banking Law } \\
\text { 373). } \\
\text { - Criminal law establishes the usury cap at an annual interest rate of } 25 \% \text { (NY Penal Code 190.40). }\end{array}$ \\
\hline
\end{tabular}




\begin{tabular}{|c|c|c|c|c|}
\hline States & $\begin{array}{l}\text { Permissive or } \\
\text { restrictive? }\end{array}$ & Related statute & Effective dates & "Supplementary information and anecdotes \\
\hline North Carolina & Restrictive & $\begin{array}{l}\text { N.C. Gen. Stat. 53- } \\
\text { 281; N.C. Gen. } \\
\text { Stat. } 53-173\end{array}$ & $\begin{array}{l}\text { Act to regulate } \\
\text { payday lending } \\
\text { expired in July } \\
2001 \text { (extended to } \\
\text { August } 31,2001 \text { ); } \\
\text { The state explicitly } \\
\text { banned payday } \\
\text { lending in } \\
\text { December } 2005\end{array}$ & $\begin{array}{l}\text { - The legislation that set the maximum annual interest rate on small loans (for a loan amount up to } \$ 600 \text { ) to } 36 \% \\
\text { was effective in July } 1981 \text { (N.C. Gen. Stat. 53-173). } \\
\text { - In October 1997, the state implemented the state check-cashing act to permit and regulate payday lending } \\
\text { activities. In 2001, the law expired and state legislators did not renew the legislation since then (N.C. Gen. Stat. } \\
\text { 53-281). } \\
\text { - In December 2005, the state formally prohibited payday lending by banning in-state firms to lend under the } \\
\text { authority of out-of-state banks. }\end{array}$ \\
\hline North Dakota & Permissive & $\begin{array}{l}\text { N.D. Cent. Code } \\
13-08-01 \text { et seq. }\end{array}$ & $\begin{array}{l}\text { Effective in April } \\
2001\end{array}$ & $\begin{array}{l}\text { - The state initiated regulation of payday lending industry in } 2001 \text {. } \\
\text {-The annual percentage rate on a } 14 \text {-day } \$ 100 \text { loan is } 521 \% \text { with a maximum loan amount of } \$ 500 \text {. }\end{array}$ \\
\hline Ohio & Permissive & $\begin{array}{l}\text { Ohio Rev. Code } \\
\text { Ann. } 1321.35 \text { et } \\
\text { seq. }\end{array}$ & $\begin{array}{l}\text { Payday lending was } \\
\text { permitted in } \\
\text { December } 51995\end{array}$ & $\begin{array}{l}\text { - The state legislature legalized payday industry in } 1995 \text { by exempting payday lending from usury laws. The } \\
\text { legislation allowed payday lenders to charge up to } 391 \% \text { as annual percentage rate. } \\
\text { - In 2008, the state enacted the Short-Term Lender Law to protect borrowers from unfair lending practices. It } \\
\text { restricts lenders from advancing short-term loans over electronic media (phone, email or through internet). } \\
\text { Among other provisions, the maximum loan amount and annual percentage rate are capped at } \$ 500 \text { and } 28 \% \\
\text { respectively. } \\
\text { - However, the payday lenders bypassed the law by registering as mortgage lenders and credit service } \\
\text { organization who come under the purview of the state's Mortgage Lending Act and the Small Loan Act. These } \\
\text { acts have much less restrictions in comparison to the Short-term Lender Law and allow lenders to charge } \\
\text { additional (service) fees in addition to the interest rates permitted by the respective acts. }\end{array}$ \\
\hline Oklahoma & Permissive & $\begin{array}{l}\text { Okla. Stat. Tit. } 59 \\
\S \S 3101 \text { et seq. }\end{array}$ & $\begin{array}{l}\text { Effective in } \\
\text { September } 2003\end{array}$ & $\begin{array}{l}\text { - The } 2003 \text { act (that regulates payday lending) is also known as the 'Deferred Deposit Lending Act'. The state's } \\
\text { Department of Consumer Credit regulates payday lending. } \\
\text { - The annual percentage rate on 14-day } \$ 100 \text { loan is approximately } 390 \% \text { with a maximum loan amount of } \\
\$ 500 \text {. }\end{array}$ \\
\hline
\end{tabular}




\begin{tabular}{|c|c|c|c|c|}
\hline States & $\begin{array}{l}\text { Permissive or } \\
\text { restrictive? }\end{array}$ & Related statute & Effective dates & Supplementary information and anecdotes \\
\hline Oregon & $\begin{array}{l}\text { Restrictive } \\
\text { under } \\
\text { conditions }\end{array}$ & $\begin{array}{l}\text { 54 Or. Rev. Stat. } \S \\
725 \text { A. } 010 \text { et seq.; } \\
725.600 \text { et seq. }\end{array}$ & $\begin{array}{l}\text { Act relating to } \\
\text { regulation of } \\
\text { payday industry } \\
\text { was implemented in } \\
\text { June } 2003 \\
\text { The } 36 \% \text { annual } \\
\text { interest rate cap was } \\
\text { implemented in } \\
\text { June } 2007\end{array}$ & $\begin{array}{l}\text { - In } 2003 \text {, the state implemented a law that regulated most types of payday loans. } \\
\text { - In } 2007 \text {, the state capped payday loans' annual percentage rate at } 36 \% \text {. However, the state allows lenders to } \\
\text { charge an origination fee that can range from } \$ 10 \text { to } \$ 30 \text { per } \$ 100 \text { lent to the borrowers. }\end{array}$ \\
\hline Pennsylvania & Restrictive & $\begin{array}{l}7 \text { P.S. } \S 6203 ; \text { Pa. } \\
\text { Stat. Ann. } \S \S 6201 \\
\text { et seq.; Pa. Stat. } \\
\text { Ann. } § 2325 \text {. }\end{array}$ & $\begin{array}{l}\text { Payday lending is } \\
\text { restricted by the } \\
\text { Consumer Discount } \\
\text { Company Act } \\
\text { enacted in April } \\
1937 . \\
\text { Effective in April } \\
1998 \text {, the state } \\
\text { implemented a law } \\
\text { to prohibit check- } \\
\text { cashing firms from } \\
\text { issuing loans based } \\
\text { on post-dated } \\
\text { checks }\end{array}$ & $\begin{array}{l}\text { - Payday lending is restricted under the terms of the Consumer Discount Company Act (Pa. Stat. Ann. } \S \S 6201 \text { et } \\
\text { seq.). } \\
\text { - Check cashers are prohibited from making payday loans (Pa. Stat. Ann. } \S 2325 \text { ). } \\
\text { - As far as } 1963 \text {, no entity was allowed to make loans in amount less than } \$ 3500 \text { and charge an annual percentage } \\
\text { rate in excess of } 6 \%\end{array}$ \\
\hline Rhode Island & Permissive & $\begin{array}{l}\text { R.I. Stat. Ann. 19- } \\
\text { 14.4-1 et seq. }\end{array}$ & $\begin{array}{l}\text { Effective in July } \\
2001\end{array}$ & $\begin{array}{l}\text { - Historically, the state had a usury cap of } 36 \% \text { (as annual percentage rate) that prevented the payday loan debt } \\
\text { trap. The act was known as the small loan law. } \\
\text { - In } 2001 \text {, payday lenders were exempted from the small loan law. } \\
\text { - The annual percentage rate on a 14-day } \$ 100 \text { loan is } 260 \% \text {. }\end{array}$ \\
\hline South Carolina & Permissive & $34-39-110$ et seq. & $\begin{array}{l}\text { Effective in June } \\
1998\end{array}$ & $\begin{array}{l}\text { - The } 1998 \text { act is also cited as the state's 'Deferred Presentment Services Act'. The act was implemented to } \\
\text { permit and regulate payday loans. } \\
\text { - The maximum loan amount is } \$ 550 \text { with an annual percentage rate on a 14-day } \$ 100 \text { loan ranging up to } 390 \% \text {. }\end{array}$ \\
\hline
\end{tabular}




\begin{tabular}{|c|c|c|c|c|}
\hline States & $\begin{array}{l}\text { Permissive or } \\
\text { restrictive? }\end{array}$ & Related statute & Effective dates & Supplementary information and anecdotes \\
\hline South Dakota & $\begin{array}{l}\text { Permissive } \\
\text { until } \\
\text { November } \\
2016\end{array}$ & $54-4-36$ et seq. & $\begin{array}{l}\text { Effective in } \\
\text { February } 1998\end{array}$ & $\begin{array}{l}\text { - The state eliminated its usury ceiling in } 1980 \text { to promote the credit card industry. } \\
\text { - The payday lending has been regulated in the state since the } 1998 \text { legislation. In a legislation dated February } \\
\text { 2004, the state formally introduced the definition of payday loans. } \\
\text { - There were no regulation on loan term or finance charges. } \\
\text { - However, in November } 2016 \text {, the state's voters approved a ballot initiative (by a } 75 \text { percent vote) to cap } \\
\text { annual interest rates for payday, car title and instalment loans at } 36 \% \text {. }\end{array}$ \\
\hline Tennessee & Permissive & $\begin{array}{l}\text { Tenn. Code Ann. } \\
45-17-101 \text { et seq. }\end{array}$ & $\begin{array}{l}\text { Effective in } \\
\text { October } 1997 \\
\text { (approved in May } \\
\text { 1997) }\end{array}$ & $\begin{array}{l}\text { - Payday lending stores existed in the state before 1997. The 'Deferred Presentment Services Act' in } 1997 \\
\text { explicitly authorized payday loans with some regulation. } \\
\text { - The annual percentage rate on a } 14 \text {-day } \$ 100 \text { loan is approximately } 459 \% \text {. }\end{array}$ \\
\hline Texas & Permissive & $\begin{array}{l}\text { Tex. Fin. Code } \S \S \\
393 \text { et seq.; Tex. } \\
\text { Fin. Code } \S \S \\
342.004\end{array}$ & $\begin{array}{l}\text { Tex. Fin. Code } \S \S \\
393 \text { et seq.: Act } \\
\text { related to payday } \\
\text { lending was } \\
\text { effective in } \\
\text { September } 1997 \\
\text { Tex. Fin. Code } \S \S \\
\text { 342.004: Effective } \\
\text { in September } 1999\end{array}$ & $\begin{array}{l}\text { - The state has been regulating payday lending since } 1997 . \\
\text { - The legislation enacted in } 1999 \text { caps the interest rate at } 10 \% \text {. However, there are no restrictions on finance } \\
\text { charges and credit access business fees. } \\
\text { - A } 2011 \text { state legislation (HB } 2594 \text {; effective from January 2012) requires credit services organizations to be } \\
\text { regulated by the state and to obtain a license for their business at each location where they operate. HB } 2592 \\
\text { requires detailed disclosures regarding the fees and interest rates. } \\
\text { - The average annual percentage rate charged on } 14 \text {-day } \$ 100 \text { loan can range up to } 410 \% \text {. }\end{array}$ \\
\hline Utah & Permissive & $\begin{array}{l}\text { Utah Code Ann. } 7- \\
\text { 23-101 et seq. }\end{array}$ & $\begin{array}{l}\text { Effective in March } \\
1999\end{array}$ & $\begin{array}{l}\text { - The } 1999 \text { legislation also known as the 'Check Cashing Registration Act' was enacted to authorize and regulate } \\
\text { payday lending in the state. } \\
\text { - There is no limit on loan amount or finance charges for payday loans. }\end{array}$ \\
\hline Vermont & Restrictive & $\begin{array}{l}\text { Vt. Stat. Ann. tit. } 9 \\
\text { § 41a; } 8 \text { V.S.A. } \\
2519(\text { a) }(13)\end{array}$ & $\begin{array}{l}\text { Payday lending is } \\
\text { restricted by the } \\
\text { provisions of small } \\
\text { loan law that was } \\
\text { originally enacted } \\
\text { in April } 1937\end{array}$ & $\begin{array}{l}\text { - The small loan law of the state prohibited any entity to engage in business of making loans of an amount less } \\
\text { than or equal to } \$ 300 \text { and charge an annual interest rate of over } 6 \% \text { (Public Act No. 184). } \\
\text { - In April 1980, the state legislation broadened the act to include licensed lenders generally, eliminated the } \\
\text { existing } \$ 1,500 \text {-loan limit (small loans) to include all licensed lenders in general. The chargeable annual interest } \\
\text { rate on loans was capped at } 18 \% \text { (Vt. Stat. Ann. tit. } 9 \S 41 \mathrm{a} \text { ). } \\
\text { - Further the legislation banning loans based on checks held for future deposit is effective from January } 2002 \\
\text { (V.S.A. } 2519 \text { (a)(13)). }\end{array}$ \\
\hline
\end{tabular}




\begin{tabular}{|c|c|c|c|c|}
\hline States & $\begin{array}{l}\text { Permissive or } \\
\text { restrictive? }\end{array}$ & Related statute & Effective dates & Supplementary information and anecdotes \\
\hline Virginia & Permissive & $\begin{array}{l}\text { Va. Code Ann. } \S \S \\
6.2-1800 \text { et seq. }\end{array}$ & $\begin{array}{l}\text { Effective in May } \\
2002\end{array}$ & $\begin{array}{l}\text { - The state enacted a legislation in } 2002 \text { (the 'Payday Loan Act') to authorize payday lending in the state and } \\
\text { exempted the industry from the existing } 36 \% \text { annual interest rate cap. } \\
\text { - With a maximum loan amount of } \$ 500 \text {, the annual percentage rate on a } 14 \text {-day } \$ 100 \text { loan can be as high as } \\
688 \% \text {. } \\
\text { - Currently, the state's general assembly is reviewing two bills that would impose restrictions on payday lending } \\
\text { activities. }\end{array}$ \\
\hline Washington & Permissive & $\begin{array}{l}\text { Wash. Rev. Code } \\
\text { Ann. } 31.45 .010 \text { et } \\
\text { seq. }\end{array}$ & $\begin{array}{l}\text { Effective in April } \\
1995\end{array}$ & $\begin{array}{l}\text { - The } 1995 \text { legislation also cited as the 'Check Cashers and Sellers Act' is related to regulation and licensing } \\
\text { requirements of lenders of small loans (loans up to an amount of } \$ 500 \text { ). } \\
\text { - In } 2009 \text {, the state passed a consumer protection bill aimed at reducing the payday loan cycle of debt. Some of } \\
\text { restrictions incorporated include - extension of time to pay back loans; ensuring limits to borrowings; reduction } \\
\text { in the requirement for additional loans to pay back the original loan; capping the maximum number of loans } \\
\text { lenders can advance to } 8 \text { during any } 12 \text {-month period. } \\
\text { - The annual percentage rate on } 14 \text {-day } \$ 100 \text { loan is } 390 \% \text {. The maximum loan amount is } \$ 700 \text { or } 30 \% \text { of gross } \\
\text { monthly income, whichever is less. }\end{array}$ \\
\hline West Virginia & Restrictive & $\begin{array}{l}\text { W. Va. Code } \S \\
46 \text { A-4-101 et seq.; } \\
\S \S 32 \text { A-3-1 et seq. }\end{array}$ & $\begin{array}{l}\text { The small loan act } \\
\text { was effective in } \\
\text { July } 1925 \\
\text { (approved by } \\
\text { governor in April } \\
\text { 1925) } \\
\text { Check cashing } \\
\text { business was } \\
\text { prohibited in April } \\
1998\end{array}$ & $\begin{array}{l}\text { - Payday lending is restricted by the legislative provisions of the small loan act which was originally enacted in } \\
1925 . \text { For businesses engaged in lending amount of } \$ 300 \text { or less, the } 1925 \text { legislation made it unlawful to charge } \\
\text { an annual interest rate of } 6 \% \text {. } \\
\text { - Check cashers are restricted from advancing loans on a check held for future deposit ( } \$ \S 32 \mathrm{~A}-3-1 \text { et seq.). } \\
\text { - Currently, the small loan act restricts annual percentage rate on loans up to a sum of } \$ 2000 \text { to } 31 \% \text {. }\end{array}$ \\
\hline Wisconsin & Permissive & Wis. Stat. 138.14 & $\begin{array}{l}\text { Effective in June } \\
2010\end{array}$ & $\begin{array}{l}\text { - The state was the only state not to regulate payday lending until } 2010 \text {. In } 2010 \text {, the Democrats implemented a } \\
\text { bill to regulate the locations of payday lending businesses and the capped the maximum loan amount at } \$ 1500 \\
\text { or } 35 \% \text { of gross monthly salary, whichever is less. } \\
\text { - There is no limit to the annual percentage rate that can be charged on a payday loan. }\end{array}$ \\
\hline Wyoming & Permissive & $40-14-362$ et seq & $\begin{array}{l}\text { Effective in March } \\
1996\end{array}$ & $\begin{array}{l}\text { - The } 1996 \text { legislation was implemented to regulate payday lending in the state. } \\
\text { - The annual percentage rate that can be charged on a 14-day } \$ 100 \text { loan can range up to } 780 \% \text { with no limit on } \\
\text { the loan term. }\end{array}$ \\
\hline
\end{tabular}


Notes: The above information is based on a detailed review of the states' annual legislation in HeinOnline and Lexis Advance databases. For state-specific statutes and other related details, we rely on information from the Consumer Federation of America's website (First accessed on February 23, 2018 from http://www.paydayloaninfo.org/state-information) and the Pew Charitable Trust's website (First accessed on February 20, 2018 from http://www.pewtrusts.org/en/projects/small-dollar-loans-research-project/research-and-analysis). In addition, we utilize multiple online resources and previous literature to collect state-specific information on payday lending-related policies that allowed us to identify the appropriate effective dates in HeinOnline and Lexis Advance. The additional sources are provided in Appendix Table A.3. 
Table A.2: Pre-payday lending restriction summary of variables (mean/ proportion)

\begin{tabular}{|c|c|c|c|c|c|c|c|c|}
\hline \multirow[b]{2}{*}{ Variables } & \multicolumn{2}{|c|}{ Restriction: Jan 2009} & \multicolumn{2}{|c|}{ Restriction: July 2010} & \multicolumn{2}{|c|}{ Restriction: March 2011} & \multicolumn{2}{|c|}{ Restriction: Nov 2010} \\
\hline & Control states & $\begin{array}{c}\text { New } \\
\text { Hampshire }\end{array}$ & Control states & Arizona & Control states & Arkansas & Control states & Montana \\
\hline \multicolumn{9}{|l|}{ Outcome variables } \\
\hline NAICS 522390 establishments rate & 5.73 & $2.60^{* * *}$ & 5.95 & $8.34^{* *}$ & 6.07 & $4.39^{*}$ & 5.95 & $3.42^{* *}$ \\
\hline All non-business bankruptcy filings rate & 125.65 & $71.77^{* *}$ & 124.95 & 109.40 & 125.03 & $169.01^{* * *}$ & 125.29 & 88.91 \\
\hline Chapter 7 non-business bankruptcy filings rate & 91.88 & $61.90^{*}$ & 91.16 & 90.33 & 91.11 & 97.38 & 91.38 & 78.46 \\
\hline Chapter 13 non-business bankruptcy filings rate & 33.71 & $9.82^{* *}$ & 33.72 & $18.87^{* *}$ & 33.85 & $71.58^{* * *}$ & 33.83 & 10.38 \\
\hline Mortgage delinquency (\%) & 1.89 & 1.05 & 2.49 & 3.74 & 2.91 & 2.06 & 2.49 & 1.55 \\
\hline Auto loan delinquency $(\%)$ & 2.63 & $1.83^{* *}$ & 2.89 & $3.97^{* *}$ & 3.13 & 2.79 & 2.89 & 2.23 \\
\hline Student loan delinquency (\%) & 7.02 & 6.29 & 7.27 & $9.46^{* *}$ & 7.54 & 8.61 & 7.27 & 8.34 \\
\hline Robbery rate & 111.96 & $33.84^{* * *}$ & 111.38 & $145.82^{*}$ & 109.79 & 90.82 & 111.38 & $25.17^{* * *}$ \\
\hline Property crime rate & $3,581.95$ & $2,037.47^{* * *}$ & $3,531.65$ & $4,879.94^{* *}$ & $3,480.57$ & $3,828.41$ & $3,531.65$ & $2,966.34^{* *}$ \\
\hline \multicolumn{9}{|l|}{ Predictor Variables } \\
\hline Female population proportion & 0.51 & 0.51 & 0.51 & $0.50^{* *}$ & 0.51 & 0.51 & 0.51 & $0.50^{* * *}$ \\
\hline White population proportion & 0.82 & $0.96^{* * *}$ & 0.82 & 0.87 & 0.82 & 0.82 & 0.82 & $0.92^{* *}$ \\
\hline Adult population proportion & 0.75 & $0.76^{* *}$ & 0.75 & $0.74^{* *}$ & 0.75 & 0.75 & 0.75 & $0.76^{* *}$ \\
\hline Total arrest rate & $4,089.92$ & $3,076.15^{* *}$ & $4,100.09$ & $5,352.12^{* *}$ & $4,080.99$ & $4,367.00$ & $4,100.09$ & $2,656.97^{* * *}$ \\
\hline Unemployment rate & 5.01 & $3.80^{* *}$ & 5.43 & 5.61 & 5.79 & 5.93 & 5.43 & 4.64 \\
\hline Real GDP per capita & $44,441.16$ & $47,202.25$ & $44,419.36$ & $41,292.11$ & $44,459.31$ & $34,293.80^{* * *}$ & $44,419.36$ & $35,455.11^{* * *}$ \\
\hline Poverty rate & 12.17 & $5.91^{* * *}$ & 12.36 & $15.46^{* *}$ & 12.59 & $16.55^{* * *}$ & 12.36 & 13.63 \\
\hline SNAP recipient rate & 8.38 & $3.87^{* * *}$ & 8.69 & 8.94 & 9.14 & $12.77^{* * *}$ & 8.69 & 8.11 \\
\hline Medicaid recipient rate & 14.45 & $7.98^{* * *}$ & 14.73 & $17.47^{*}$ & 15.05 & $21.01^{* * *}$ & 14.73 & $9.02^{* * *}$ \\
\hline Commercial bank - rate of number of institution & 4.63 & $0.86^{* * *}$ & 4.57 & $0.82^{* * *}$ & 4.50 & 5.40 & 4.57 & $8.20^{* * *}$ \\
\hline Savings Institutions - rate of number of institution & 0.45 & $1.37^{* * *}$ & 0.44 & $0.05^{* * *}$ & 0.44 & $0.25^{* *}$ & 0.44 & 0.34 \\
\hline Commercial bank - Total individual loan per capita & $8,191.23$ & $3,562.32$ & $8,544.05$ & $3,881.33$ & $9,203.89$ & 998.92 & $8,544.05$ & $1,178.79$ \\
\hline Savings institution - Total individual loan per capita & 471.68 & 773.93 & 472.57 & 19.76 & 473.03 & 60.31 & 472.57 & 20.51 \\
\hline Commercial bank - Credit card loan per capita & $6,075.63$ & $3,402.50$ & $6,315.12$ & $3,832.89$ & $6,898.67$ & 134.69 & $6,315.12$ & 97.30 \\
\hline Savings institution - Credit card loan per capita & 330.40 & 14.66 & 331.72 & 19.57 & 334.18 & 6.18 & 331.72 & 0.50 \\
\hline Commercial bank - Total liabilities/ assets & 0.90 & $0.85^{* * *}$ & 0.90 & 0.90 & 0.90 & 0.90 & 0.90 & 0.90 \\
\hline Savings institution - Total liabilities/ assets & 0.89 & 0.90 & 0.89 & $0.80^{* * *}$ & 0.89 & 0.89 & 0.89 & 0.87 \\
\hline All financial establishments rate & 78.67 & $62.25^{* * *}$ & 78.42 & $67.55^{* * *}$ & 77.86 & $70.65^{*}$ & 78.42 & 81.51 \\
\hline
\end{tabular}


Notes: All rates are in terms of numbers per 100,000 state population. ${ }^{* * *, * * *}$ denote that the difference in the sample mean of the variables between control states and the treated state is statistically significant at the $1 \%, 5 \%$, and $10 \%$ level respectively. 
Table A.3: Additional sources used to verify the state-specific legislative information

\begin{tabular}{|c|c|c|}
\hline States & Citations and online links & Date first accessed \\
\hline Alabama & $\begin{array}{l}\text { 1) http://wsvceres.nl/f4320.html } \\
\text { 2) https://arisecitizens.org/index.php/component/docman/doc_view/531-hard-cash-predatory-lending-in-alabama?Itemid=44 } \\
\text { 3) http://www.gadsdentimes.com/article/DA/20060918/Sports/603228709/GT/ }\end{array}$ & February 20, 2018 \\
\hline Alaska & $\begin{array}{l}\text { 1) Fox, J. A., \& Petrini, A. (2004). Internet Payday Lending: How High-priced Lenders Use the Internet to Mire Borrowers in Debt and Evade State Consumer } \\
\text { Protections: a CFA Survey of Internet Payday Loan Sites. Consumer Federation of America. } \\
\text { 2) https://s3.amazonaws.com/files.consumerfinance.gov/f/documents/Rulemaking_Payday_Vehicle_Title_Certain_High-Cost_Installment_Loans.pdf } \\
\text { 3) http://www.grupogyc.com.gt/c54655.asp } \\
\text { 4) http://aws.state.ak.us/officeofadminhearings/Documents/BFI/BFI080689.pdf }\end{array}$ & February 21, 2018 \\
\hline Arkansas & $\begin{array}{l}\text { 1) http://stoppaydaypredatorsarkansas.org/pdfs2/payday_loans.pdf } \\
\text { 2) https://ballotpedia.org/Arkansas_Interest_Rate_Limits,_Proposed_Amendment_2_(2010) } \\
\text { 3) http://www.ncsl.org/research/financial-services-and-commerce/payday-lending-state-statutes.aspx } \\
\text { 4) Knize, M. S. (2008). Payday Lending in Louisiana,_Mississippi, and Arkansas: Toward Effective Protections for Borrowers. La. L. Rev., } 69 \text {, } 317 .\end{array}$ & February 21, 2018 \\
\hline Arizona & $\begin{array}{l}\text { 1) Rosette, R., \& Bazzazieh, S. (2013). Arizona's Win-Win Short-Term Credit Solution: Assisting Arizona's Unbanked and Underbanked While Supporting } \\
\text { Tribal Self-Determination. Ariz. St. LJ, 45, 781. } \\
\text { 2) https://www.azag.gov/sites/default/files/sites/all/docs/consumer/op-sunset-FAQ.pdf } \\
\text { 3) https://www.azleg.gov/ars/6/01263.htm } \\
\text { 4) https://s3.amazonaws.com/files.consumerfinance.gov/f/documents/Rulemaking_Payday_Vehicle_Title_Certain_High-Cost_Installment_Loans.pdf } \\
\text { 5) https://www.azcentral.com/story/news/politics/fact-check/2014/09/22/fact-check-goddard-reagan-stance-payday-loans/16057207/ } \\
\text { 6) Parrish, L. (2008). High Cost Payday Lending Traps Arizona Borrowers. Center for Responsible Lending. }\end{array}$ & February 21, 2018 \\
\hline California & $\begin{array}{l}\text { 1) ftp://leginfo.ca.gov/pub/95-96/bill/sen/sb_1951-2000/sb_1959_bill_960618_amended_asm.pdf } \\
\text { 2) http://www.woodstockinst.org/sites/default/files/attachments/The\%20Case\%20for\%20Banning\%20Payday\%20Lending\%20-\%20June\%202013.pdf } \\
\text { 3) http://www.dbo.ca.gov/Licensees/Payday_Lenders/Archives/pdfs/CDDTL07_Report.pdf } \\
\text { 4) Morse, A. (2011). Payday lenders: Heroes or villains?. Journal of Financial Economics, 102(1), 28-44. }\end{array}$ & February 21, 2018 \\
\hline Colorado & $\begin{array}{l}\text { 1) Chessin, P. (2005). Borrowing from Peter to pay Paul: A statistical analysis of Colorado's deferred deposit loan act. Denv. UL Rev., } 83,387 . \\
\text { 2) https://www.denverpost.com/2017/08/03/colorado-payday-loans-reform-laws-center-for-responsible-lending/ } \\
\text { 3) http://www.coloradoindependent.com/150487/colorado-payday-loan-policy-and-the-art-of-legilsative-compromise }\end{array}$ & February 23, 2018 \\
\hline
\end{tabular}




\section{States}

Connecticut

1) https://www.cga.ct.gov/2001/pub/Chap673.htm

2) https://visual.ly/community/infographic/business/where-are-payday-loans-banned

3) https://www.cga.ct.gov/PS98/rpt\%5Colr\%5Chtm/98-R-0850.htm

Delaware 1) http://delcode.delaware.gov/sessionlaws/ga134/chp022.shtml

2) https://wegiveloans.com/payday-loans-in-delaware

3) https://www.opploans.com/rates-terms/delaware/

4) http://paydayloanlegislation.com/delaware.html

5) https://insight.kellogg.northwestern.edu/article/the_real_costs_of_credit_access

District of

Columbia

1) Bhutta, N., Goldin, J., \& Homonoff, T. (2016). Consumer borrowing after payday loan bans. The Journal of Law and Economics, 59(1), $225-259$.

2) http://paydayloanlegislation.com/district-of-columbia.html

3) https://disb.dc.gov/sites/default/files/dc/sites/disb/publication/attachments/deferred_deposit_check_cashing_\%28payday_lending\%29.pdf

4) https://www.in.gov/dfi/2366.htm

5) Fox, J. A. (1998). The Growth of Legal Loan Sharking: a report on the payday loan industry. Washington, DC: Consumer Federation of America.

6) http://mothersoutreachnetwork.org/payday-lending-briefing/

7) https://law.justia.com/codes/district-of-columbia/2012/division-v/title-28/subtitle-ii/chapter-33/section-28-3301.html

Florida

1) Davis, D. (2016). Perfect Storm: Payday Lenders Harm Florida Consumers Despite State Law.

2) https://www.flofr.com/StaticPages/PaydayLenders.htm

3) http://www.veritecs.com/case-studies/floridas-deferred-presentation-database-and-program-solution/

4) http://www.responsiblelending.org/sites/default/files/nodes/files/research-publication/crl_perfect_storm_florida_mar2016_0.pdf

Georgia 1) https://visual.ly/community/infographic/business/where-are-payday-loans-banned

2) https://law.georgia.gov/lawsuit-against-western-sky-financial

3) https://www.georgiawatch.org/wp-content/uploads/2015/01/Georgia-Watch-Payday-Lending-Report.pdf

4) Worley, L. F. (1964). The Georgia Industrial Loan Act of 1955. The Georgia Review, 18(2), 193-199.

Hawaii 1) https://www.pressreader.com/usa/honolulu-star-advertiser/20150408/281762742773694

2) Fox, J. A. (2000). Safe harbor for usury: Recent developments in payday lending. Advancing the Consumer Interest, 12(1), 7-12.

3) http://files.hawaii.gov/auditor/Reports/2005/05-11.pdf

1) https://www.finance.idaho.gov/ConsumerFinance/Documents/Idaho-Credit-Code-Fast-Facts-With-Fiscal-Annual-Report-Data-01012015.pdf

2) https://www.opploans.com/rates-terms/idaho/

3) https://www.finance.idaho.gov/Education/Documents/Payday-Loans-in-Idaho.pdf
Dates first accessed

February 23, 2018

February 24, 2018

February 24, 2018

February 27, 2018

February 27, 2018

February 27, 2018

February 27, 2018 


\begin{tabular}{|c|c|c|}
\hline States & Citations and online links & Dates first accessed \\
\hline Illinois & $\begin{array}{l}\text { 1) https://www.idfpr.com/dfi/ccd/3YearPLRAReportDFI.pdf } \\
\text { 2) http://paydaylendingfacts.org/2016/07/25/illinois-payday-lenders-bypassed-regulation-lengthening-term-loans-provided/ } \\
\text { 3) http://www.ilga.gov/legislation/billstatus.asp?DocNum=1133\&GAID=11\&GA=97\&DocTypeID=SB\&LegID=55950\&SessionID=84 } \\
\text { 4) http://www.ilga.gov/legislation/ilcs/ilcs5.asp?ActID=2697\&ChapterID=67 } \\
\text { 5) http://paydayloanlegislation.com/illinois.html }\end{array}$ & March 1, 2018 \\
\hline Indiana & $\begin{array}{l}\text { 1) https://consumerfed.org/pdfs/pdlrentabankreport.pdf } \\
\text { 2) https://www.indianalegalservices.org/sites/indianalegalservices.org/files/Payday\%20Loans\%20\%20-\%20\%20PDF-Brochure.pdf } \\
\text { 3) https://www.in.gov/dfi/2366.htm } \\
\text { 4) Barth, J. R., Hilliard, J., Jahera, J. S., \& Sun, Y. (2016). Do state regulations affect payday lender concentration?. Journal of Economics and Business, 84, } \\
\text { 14-29. }\end{array}$ & March 1, 2018 \\
\hline Iowa & 1) https://www.iowaattorneygeneral.gov/media/cms/87_5F783B39CA5BD.pdf & March 1, 2018 \\
\hline Kansas & $\begin{array}{l}\text { 1) https://wegiveloans.com/payday-loans-in-kansas } \\
\text { 2) http://www.kslegresearch.org/KLRD-web/Publications/BriefingBook/2017Briefs/E-2-PaydayLoanRegulation.pdf }\end{array}$ & March 2, 2018 \\
\hline Kentucky & $\begin{array}{l}\text { 1) https://www.in.gov/dfi/2366.htm } \\
\text { 2) http://www.kbcpublicaffairs.org/2011/11/23/kbc-takes-stand-on-payday-lending/ } \\
\text { 3) http://migration.kentucky.gov/Newsroom/eppc_ofi/043010database.htm }\end{array}$ & March 2, 2018 \\
\hline Louisiana & $\begin{array}{l}\text { 1) Knize, M. S. (2008). Payday Lending in Louisiana, Mississippi, and Arkansas: Toward Effective Protections for Borrowers. La. L. Rev., } 69 \text {, } 317 . \\
\text { 2) Kurban, H., Diagne, A. F., \& Otabor, C. (2014). The Economic Impact of Payday Lending in Economically Vulnerable Communities. }\end{array}$ & March 2, 2018 \\
\hline Maine & $\begin{array}{l}\text { 1) http://legislature.maine.gov/statutes/9-A/title9-Asec2-401.html } \\
\text { 2) https://legal-dictionary.thefreedictionary.com/Uniform+Consumer+Credit+Code } \\
\text { 3) https://legislature.maine.gov/statutes/32/title32ch80.pdf } \\
\text { 4) http://payday-today.us/locations_maine_payday_loans.php } \\
\text { 5) http://law.jrank.org/pages/10996/Uniform-Consumer-Credit-Code.html } \\
\text { 6) http://legislature.maine.gov/statutes/9-A/title9-Asec1-202.html } \\
\text { 7) http://www.ustatesloans.org/state-me.html } \\
\text { 8) http://paydayloanlegislation.com/maine.html } \\
\text { 9) Nicholson, I. (2008). The truth about payday loans: How hardworking Coloradans take the bait and get caught in a cycle of debt. The Bell Policy Center } \\
\text { and the Center for Policy Entrepreneurship. Denver: February. }\end{array}$ & March 2, 2018 \\
\hline
\end{tabular}




\begin{tabular}{|c|c|c|}
\hline States & Citations and online links & Dates first acces \\
\hline Maryland & $\begin{array}{l}\text { 1) http://www.dllr.state.md.us/finance/advisories/advisory7-09a.shtml } \\
\text { 2) https://repository.law.umich.edu/cgi/viewcontent.cgi?article=1398\&context=articles } \\
\text { 3) Nicholson, I. (2008). The truth about payday loans: How hardworking Coloradans take the bait and get caught in a cycle of debt. The Bell Policy Center } \\
\text { and the Center for Policy Entrepreneurship. Denver: February. } \\
\text { 4) Fox, J. A., \& Mierzwinski, E. (2001). Rent-a-bank payday lending: How banks help payday lenders evade state consumer protections. Consumer } \\
\text { Federation of America and US Public Interest. } \\
\text { 5) Plum, J. J. (1978). Casenotes: Usury_-Maryland Annotated Code, Article } 49 \text {-a Lender's Retention of Loan Related Costs, Unless Exempted, Constitutes } \\
\text { Interest_-Unpaid Balance Is That Sum Actually Owed by a Borrower to a Lender. Tri-County Fed. Sav. \& Loan Ass'n v. Lyle, 280 Md. 69, 371 A. 2d 424 } \\
\text { (1977). University of Baltimore Law Review, 7(2), 7. } \\
\text { 6) http://www.gfrlaw.com/files/upload/Credit\%20Laws\%20book_Feb22pm.pdf }\end{array}$ & March 3, 2018 \\
\hline Massachusetts & $\begin{array}{l}\text { 1) http://archives.lib.state.ma.us/actsResolves/1898/1898acts0577.pdf } \\
\text { 2) http://archives.lib.state.ma.us/handle/2452/89589 }\end{array}$ & March 3, 2018 \\
\hline Michigan & $\begin{array}{l}\text { 1) http://www.mcul.org/files/mcul/1/image/News-Photos/001\%20Jenna/August\%202017/State\%20Issue\%20Brief\%20- } \\
\text { \%20Payday\%20Lending\%20Expansion.pdf } \\
\text { 2) http://paydayloanlegislation.com/michigan.html } \\
\text { 3) https://www.advancecash.info/Michigan_Cash_Advance } \\
\text { 4) http://www.michigan.gov/ag/0,4534,7-359-81903_20942-171016--,00.html } \\
\text { 5) https://caselaw.findlaw.com/mi-court-of-appeals/1508616.html }\end{array}$ & March 5, 2018 \\
\hline Minnesota & $\begin{array}{l}\text { 1) http://www.senate.mn/senators/65pappas/press/Preyday\%20Lending.pdf } \\
\text { 2) http://www.startribune.com/one-last-hurdle-for-payday-lending-reform-in-minnesota/259146171/ }\end{array}$ & March 5, 2018 \\
\hline Mississippi & $\begin{array}{l}\text { 1) Renuart, E., \& Fox, J. A. (2000). Payday Loans: A High Cost for a Small Loan in Low-Income and Working Conditions. Clearinghouse Rev., } 34,589 . \\
\text { 2) https://www.opploans.com/rates-terms/mississippi/ }\end{array}$ & March 5, 2018 \\
\hline Missouri & $\begin{array}{l}\text { 1) http://www.everyvoicecenter.org/wp-content/uploads/2015/05/Indebted-Final.pdf } \\
\text { 2) http://www.ustatesloans.org/state-mo.html } \\
\text { 3) https://www.efis.psc.mo.gov/mpsc/commoncomponents/viewdocument.asp?DocId=935476227 } \\
\text { 4) http://www.stltoday.com/business/local/why-the-payday-loan-industry-is-declining-in-missouri/article_405e3164-6b9d-557f-b42b-67681317ffbe.html } \\
\text { 5) https://www.mdn.org/2011/STORIES/HB656.HTM } \\
\text { 6) http://extension.missouri.edu/cfe/wcap/Show-MePredatoryLendingReport.pdf }\end{array}$ & March 8, 2018 \\
\hline
\end{tabular}




\begin{tabular}{|c|c|c|}
\hline States & Citations and online links & Dates first accessed \\
\hline Montana & $\begin{array}{l}\text { 1) https://ballotpedia.org/Montana_Loan_Interest_Rate_Limit,_I-164_(2010) } \\
\text { 2) https://www.federalreserve.gov/pubs/feds/2013/201381/figure_data.html } \\
\text { 3) Hynes, R. (2012). Payday lending, bankruptcy, and insolvency. Wash. \& Lee L. Rev., 69, } 607 . \\
\text { 4) Fox, J. A. (2000). Safe harbor for usury: Recent developments in payday lending. Advancing the Consumer Interest, 12(1), 7-12. } \\
\text { 5) https://www.npr.org/2010/11/17/131378384/payday-lenders-close-operations-in-montana } \\
\text { 6) http://banking.mt.gov/MortgageConsumerFinance/ddl\#294243840-licensing } \\
\text { 7) http://missoulian.com/news/opinion/columnists/montana-s-rate-cap-also-applies-to-online-loans/article_0e24015a-3168-11e1-b35b-0019bb2963f4.html } \\
\text { 8) https://www.neweconomynyc.org/wp-content/uploads/2016/04/Montana-CFPB-Letter.pdf }\end{array}$ & March 8, 2018 \\
\hline Nebraska & $\begin{array}{l}\text { 1) http://www.ustatesloans.org/state-ne.html } \\
\text { 2) http://www.omaha.com/news/legislature/omaha-senators-bill-would-slash-payday-loan-interest-rates/article_75f79974-d760-11e6-88b4-eb72d360c4ef.html } \\
\text { 3) http://lwwne.typepad.com/files/PayDay\%20Lending\%20Report--Rea\%20011511.pdf }\end{array}$ & March 8, 2018 \\
\hline Nevada & $\begin{array}{l}\text { 1) https://www.nevadaappeal.com/news/payday-loan-companies-targeted/ } \\
\text { 2) https://thenevadaindependent.com/article/indy-explains-lawmakers-push-additional-rules-high-interest-payday-loans } \\
\text { 3) http://www.ustatesloans.org/state-nv.html } \\
\text { 4) https://www.leg.state.nv.us/Division/Research/Publications/PandPReport/07-FIML.pdf } \\
\text { 5) http://nevadaforward.com/2017/03/16/prey-day-payday-loan-bills-nvleg/ }\end{array}$ & March 9, 2018 \\
\hline $\begin{array}{l}\text { New } \\
\text { Hampshire }\end{array}$ & $\begin{array}{l}\text { 1) https://www.samedaypayday.com/New-Hampshire-Payday-Loan } \\
\text { 2) https://www.loanspayday.info/New_Hampshire_Payday_Loans } \\
\text { 3) Bhutta, N. (2014). Payday loans and consumer financial health. Journal of Banking \& Finance, 47, 230-242. } \\
\text { 4) Bhutta, N., Goldin, J., \& Homonoff, T. (2016). Consumer borrowing after payday loan bans. The Journal of Law and Economics, 59(1), 225-259. } \\
\text { 5) http://paydayloanlegislation.com/new-hampshire.html } \\
\text { 6) https://www.nhfamilylawblog.com/2008/05/articles/debt/new-legislation-re-payday-loans/ } \\
\text { 7) http://www.gencourt.state.nh.us/legislation/2008/HB0267.html } \\
\text { 8) Prager, R. A. (2009). Determinants of the locations of payday lenders, pawnshops and check-cashing outlets. Washington, DC: Federal Reserve Board. }\end{array}$ & March 9, 2018 \\
\hline New Jersey & 1) https://law.justia.com/cases/new-jersey/appellate-division-published/1981/179-n-j-super-344-0.html & March 12, 2018 \\
\hline New Mexico & $\begin{array}{l}\text { 1) https://buckleysandler.com/blog/2017-04-18/new-mexico-enacts-new-laws-affecting-payday-lenders-check-cashing-service-providers-and-enforcement- } \\
\text { service-contracts-warranties }\end{array}$ & March 12, 2018 \\
\hline New York & 1) https://citylimits.org/2012/07/16/payday-loans-illegal-on-the-street-thrive-in-new-yorks-cyberspace/ & March 12, 2018 \\
\hline
\end{tabular}




\begin{tabular}{|c|c|c|}
\hline States & Citations and online links & Dates first acces \\
\hline $\begin{array}{l}\text { North } \\
\text { Carolina }\end{array}$ & $\begin{array}{l}\text { 1) https://ced.sog.unc.edu/payday-lenders-north-carolinas-capital-showdown/ } \\
\text { 2) Hefner, Scott A. "Payday Lending in North Carolina: Now You See It, Now You Don't." NC Banking Inst. } 11 \text { (2007): } 263 . \\
\text { 3) https://www.pantalassaloan.com/north-carolina-payday.html } \\
\text { 4) https://www.finder.com/payday-loans/north-carolina } \\
\text { 5) https://law.justia.com/codes/north-carolina/2010/chapter53/article15/section53-173/ }\end{array}$ & March 13, 2018 \\
\hline North Dakota & $\begin{array}{l}\text { 1) https://georgiapirg.org/news/gap/payday-lenders-evade-state-consumer-protections-renting-bank-charters } \\
\text { 2) Fox, J. A., \& Mierzwinski, E. (2001). Rent-a-bank payday lending: How banks help payday lenders evade state consumer protections. Consumer } \\
\text { Federation of America and US Public Interest. } \\
\text { 3) https://wegiveloans.com/payday-loans-in-north-dakota }\end{array}$ & March 13, 2018 \\
\hline Ohio & $\begin{array}{l}\text { 1) https://www.nolo.com/legal-encyclopedia/restrictions-payday-lending-ohio.html } \\
\text { 2) http://www.cleveland.com/consumeraffairs/index.ssf/2015/03/an_updated_illustrated_history.html - History of payday lending in Ohio } \\
\text { 3) http://www.policymattersohio.org/wp-content/uploads/2014/07/OPLC.pdf } \\
\text { 4) https://www.mydaytondailynews.com/news/ohio-couldn-limit-payday-loans-before-will-this-time-different/tzBJoijS6aCL5SqEM9y1KO/ } \\
\text { 5) http://www.responsiblelending.org/payday-lending/research-analysis/crl_ohio_analysis_nov2015.pdf } \\
\text { 6) http://www.policymattersohio.org/wp-content/uploads/2011/09/ContinuedGrowthOfPaydayLendingInOhio2008_0319.pdf } \\
\text { 7) Faller, B. D. (2008). Payday loan solutions: slaying the hydra (and keeping it dead). Case W. Res. L. Rev., 59, 125. }\end{array}$ & March 13, 2018 \\
\hline Oklahoma & $\begin{array}{l}\text { 1) http://oklahomawatch.org/2017/05/03/oklahoma-lending-bill-reflects-nationwide-industry-effort/ } \\
\text { 2) http://www.tulsaworld.com/news/capitol_report/oklahoma-house-advances-payday-loan-bill/article_471282b2-9f29-5075-8da8-f081ff9851f6.html } \\
\text { 3) https://wegiveloans.com/payday-loans-in-oklahoma } \\
\text { 4) http://newsok.com/article/2945276 } \\
\text { 5) http://paydayloanlegislation.com/oklahoma.html } \\
\text { 6) https://www.in.gov/dfi/2366.htm }\end{array}$ & March 13, 2018 \\
\hline Oregon & $\begin{array}{l}\text { 1) http://oregon.payday.loan.laws.4.loansapp2.appspot.com/ } \\
\text { 2) http://www.minyanville.com/businessmarkets/articles/csh-loans-FCFS-payday-rcii/2/25/2009/id/21326 } \\
\text { 3) http://pubcit.typepad.com/clpblog/2007/06/oregon_curbs_pa.html } \\
\text { 4) Weiler, A. Assessing the Effects of State Payday Lending Regulation on Payday Loan Usage and Economic Well-Being (Doctoral dissertation, The } \\
\text { University of Notre Dame). }\end{array}$ & March 13, 2018 \\
\hline Pennsylvania & $\begin{array}{l}\text { 1) https://www.pacode.com/secure/data/010/chapter81/chap81toc.html } \\
\text { 2) https://www.pantalassaloan.com/pennsylvania-payday-loan-laws.html } \\
\text { 3) http://www.dobs.pa.gov/Documents/Statutes/Consumer\%20Discount\%20Company\%20Act.pdf } \\
\text { 4) https://www.leagle.com/decision/195842217padampc2d4051350 }\end{array}$ & March 14, 2018 \\
\hline
\end{tabular}




\begin{tabular}{|c|c|c|}
\hline States & Citations and online links & Dates first accessed \\
\hline Rhode Island & $\begin{array}{l}\text { 1) http://www.ripayday.org/wp-content/uploads/2013/01/RI-Why36.pdf } \\
\text { 2) http://www.brownpoliticalreview.org/2013/04/why-ri-needs-payday-lending-reform/ } \\
\text { 3) Jefferson, P. N. (Ed.). (2012). The Oxford handbook of the economics of poverty. Oxford University Press on Demand. }\end{array}$ & March 14, 2018 \\
\hline $\begin{array}{l}\text { South } \\
\text { Carolina }\end{array}$ & $\begin{array}{l}\text { 1) https://www.in.gov/dfi/2366.htm } \\
\text { 2) https://wegiveloans.com/payday-loans-in-south-carolina }\end{array}$ & March 15, 2018 \\
\hline South Dakota & $\begin{array}{l}\text { 1) Walter, J. R. (2006). The 3-6-3 rule: an urban myth?. Accessed from } \\
\text { http://citeseerx.ist.psu.edu/viewdoc/download?doi=10.1.1.693.3388\&rep=rep1\&type=pdf } \\
\text { 2) http://www.ustatesloans.org/state-sd.html } \\
\text { 3) https://wegiveloans.com/payday-loans-in-south-dakota } \\
\text { 4) https://www.theatlantic.com/politics/archive/2015/03/the-odd-couple-fighting-against-predatory-payday-lending/388093/ }\end{array}$ & March 15, 2018 \\
\hline Tennessee & $\begin{array}{l}\text { 1) https://www.nashvillescene.com/news/article/13028924/harpers-investigates-the-sinister-world-of-tennessees-payday-lending-industry } \\
\text { 2) https://www.questia.com/newspaper/1P2-5727949/lobbying-money-helping-to-persuade-legislators-to } \\
\text { 3) https://metroideas.org/media/Fighting\%20Predatory\%20Lending\%20in\%20Tennessee\%20-\%20Metro\%20Ideas\%20Project.pdf }\end{array}$ & March 15, 2018 \\
\hline Texas & $\begin{array}{l}\text { 1) http://www.texasfairlending.org/the-issue/history/ } \\
\text { 2) } \mathrm{https}: / / \text { wegiveloans.com/payday-loans-in-texas } \\
\text { 3) http://forabettertexas.org/images/EO_2013_09_StateofPayday.pdf } \\
\text { 4) https://www.allmandlaw.com/2011/texas-passes-payday-and-title-loan-laws/ } \\
\text { 5) http://www.senate.state.tx.us/cmtes/78/c510/TULCCSCh2.pdf } \\
\text { 6) http://www.statutes.legis.state.tx.us/SOTWDocs/FI/htm/FI.342.htm } \\
\text { 7) http://www.statutes.legis.state.tx.us/Docs/FI/htm/FI.393.htm } \\
\text { 8) http://www.statutes.legis.state.tx.us/Docs/FI/htm/FI.341.htm\#341.001 }\end{array}$ & March 16, 2018 \\
\hline Utah & $\begin{array}{l}\text { 1) https://dfi.utah.gov/money-services/deferred-deposit-lender/ } \\
\text { 2) http://paydayloanlegislation.com/utah.html }\end{array}$ & March 16, 2018 \\
\hline Vermont & $\begin{array}{l}\text { 1) http://www.dfr.vermont.gov/sites/default/files/2015\%20Act\%20199\%20Furthering\%20Economic\%20Development.pdf } \\
\text { 2) Hubachek, F. B. (1941). The Development of Regulatory Small Loan Laws. Law and Contemporary Problems, 8(1), 108-145. }\end{array}$ & March 16, 2018 \\
\hline
\end{tabular}




\section{States}

Virginia

1) https://www.news.virginia.edu/content/virginia-payday-lending-business-growing-panel-uva-sc

Citations and online links

2) Campbell, L., Foster, M. W. M., Gulino-Passera, S., Gutierrez, L., \& Lee, K. M. (2012). Payday Lending in Virginia: The Lesser of Many Evils?. New

Voices In Public Policy, 6(1)

Washington 1) http://dfi.wa.gov/sites/default/files/reports/2015-payday-lending-report.pdf

2) https://www.propublica.org/article/how-one-state-succeeded-in-restricting-payday-loans

3) https://prezi.com/ievrtftfmtew/washington-states-payday-lending-law/

4) https://www.thestranger.com/blogs/slog/2015/03/05/21834944/the-payday-loan-reforms-that-only-payday-lenders-want

5) http://opeiu8.org/Portals/opeiu8/journal/2007/Feb2007.pdf?ver=2007-09-09-155859-773

West Virginia 1) Hubachek, F. B. (1941). The Development of Regulatory Small Loan Laws. Law and conteMporary probLeMs, 8(1), $108-145$.

2) http://www.debtconsolidationpaydayloan.com/west-virginia-payday-loan-laws/

Wisconsin

1) Fox, J. A., \& Mierzwinski, E. (2000). Show me the money! a survey of payday lenders and review of payday lender lobbying in state legislatures. US PIRG and Consumer Federation of America. February.

2) Stegman, M. A., \& Faris, R. (2003). Payday lending: A business model that encourages chronic borrowing. Economic Development Quarterly, $17(1)$, 8-32.

3) https://www.opploans.com/rates-terms/wisconsin/

4) https://docs.legis.wisconsin.gov/2009/related/acts/405
Dates first accessed

March 16, 2018

March 19, 2018

March 19, 2018

March 19, 2018

March 19, 2018 